\title{
VEGETATION OF THE ONFERNO NATURE RESERVE (RIMINI - CENTRAL ITALY) AND MANAGEMENT PROBLEMS OF SECONDARY GRASSLANDS
}

\author{
Silva ZITTI ${ }^{1}$, Michele RISMONDO ${ }^{1}$ \& Fabio TAFFETANI ${ }^{1}$
}

\begin{abstract}
This study presents a floristic and vegetational analysis of the territory of the Onferno Nature Reserve. The site extends over about 120 hectares, and is located in central Italy, in a hilly area near the Adriatic coast. It is characterised by the presence of large gypsum blocks that have karst caves, where important colonies of bats lives. This study of the vegetation allowed the description of six main vegetation series, divided into three different geosigmeta: a geomorphological unit of gypsum substrata (Gessi di Onferno); a geomorphological unit of clay substrata (Formazione del Santerno); and a geomorphological unit of compact sandstone substrata (Formazione Montecalvo in Foglia). This floristic and vegetation studies carried out on the secondary grasslands (EC Habitat 6210) have allowed the evaluation of the grazing effects on the conservation of their biodiversity, and highlight the critical nature of this management method. Furthermore, on the basis of the vegetation studies, the list of habitats according to EC Directive 92/43/CEE has been better defined and updated.
\end{abstract}

Key words: vegetation, secondary grasslands, habitat, bats, Onferno.

\section{Izvleček}

V raziskavi so predstavljeni rezultati floristične in vegetacijske analize na območju naravnega rezervata Onferno. Rezervat obsega več kot 120 hektarjev in je v srednji Italiji v gričevnatem območju ob jadranski obali. V njem so značilni veliki bloki gipsa s kraškimi jamami, kjer živijo pomembne kolonije netopirjev. V vegetacijski anlizi smo opisali šest vegetacijskih serij, razdeljenih v tri različne geosigmete: geomorfološka enota na gipsu (Gessi di Onferno); geomorfološka enota na glini (Formazione del Santerno) in geomorfološka enota na kompaktnem peščenjaku (Formazione Montecalvo in Foglia). Z rezultati floristične in vegetacijske raziskave na sekundarnih traviščih (EC Habitat 6210) smo lahko ovrednotili učinke paše na varovanje biodiverzitete in izpostavili kritične točke tega načina gospodarjenja. Na osnovi vegetacijske analize smo lahko bolje določili in dopolnili seznam habitatnih tipov v skladu s habitatno direktivo (EC Directive 92/43/CEE).

Ključne besede: vegetacija, sekundarna travišča, habitatni tipi, netopirji, Onferno.

\section{INTRODUCTION}

The Onferno Nature Reserve is a protected area of about 120 hectares that is situated in the town of Gemmano, a few kilometers from Rimini, which is an Italian area with one of the highest concentrations of tourists. The area is also a Site of Community Importance (SCI Onferno IT 409 001). Although the landscape has been heavily shaped by human activities, the more important natural elements have been preserved, largely due to the presence of the extended badlands, and especially with the gypsum substrata. This gypsum substrata of the Onferno Nature Reserve is part of the southern-most area of the large geological system of "Vena del Gesso", which unites the gypsum outcrops of the Reggio Emilia province with those of Rimini. The originality and richness of the vegetation of these gypsum outcrops in Emilia Romagna have been noted previously (Zangheri, 1936; Corbetta, 1994; Alessandrini, 1996; Laghi \& Pastorelli, 2004; Taffetani et al. 2005).

\footnotetext{
${ }^{1}$ Dip. Scienze Agrarie, Alimetari e Ambientali, Università Politecnica delle Marche, Via Brecce Bianche, 60123 Ancona
} 
A particular feature of the Onferno Nature Reserve is the numerous colonies of Chiroptera found in the karst caves that have developed along the base of the chalk complex. These bat communities are very different and they constitute the largest colonies of mixed species in northern Italy, according to Annex II of the Habitats Directive. The breeding colonies have reached about 6,000 bats that belong to seven species: Miniopterus schreibersii, Myotis blythi, Myotis myotis, Rhynolophus euryale, Rhynolophus hipposideros, Rhynolophus ferrumequinum, and Myotis emarginatus (SIC Onferno listing IT 409 001).

The conservation of these bats is strictly linked to the preservation of their natural environment, and particularly to the Bromus erectus grasslands that are their foraging areas (Priority Habitat 6210, under the Habitats Directive 92/43 EEC). Some of the grasslands of the southern sector of the Reserve that are more structured and rich in species can be included in this category; however, others represent more ruderal aspects, although they have the potential to evolve over time into more mature types of pasture. As with all secondary grasslands, their maintenance is highly dependent on the use of animals, either directly (grazing) or more indirectly (mowing). Since the total abandonment of such animal husbandry practices, to maintain these grasslands and to promote the development of further grasslands, the Reserve has for several years followed management programmes designed to ensure their active conservation, such as the Life Project for "Conservation of bats and their foraging areas in the Onferno Nature Reserve SCI site". The aim of the Life Project is of maintaining the great value of environmental biodiversity by improving the fragmentation and crop diversification in agricultural areas, maintaining the existing grasslands, and encouraging the development of abandoned areas towards the formation of permanently managed grasslands, and in this way to preserve and expand the foraging areas of the bats.

In this paper, we present the results of a floristic and vegetational study carried out for environmental characterization prior to the interventions under the Life project, and the evaluation of the subsequent results, in terms of the floristic, vegetational and serial biodiversity of this biocoenosis.

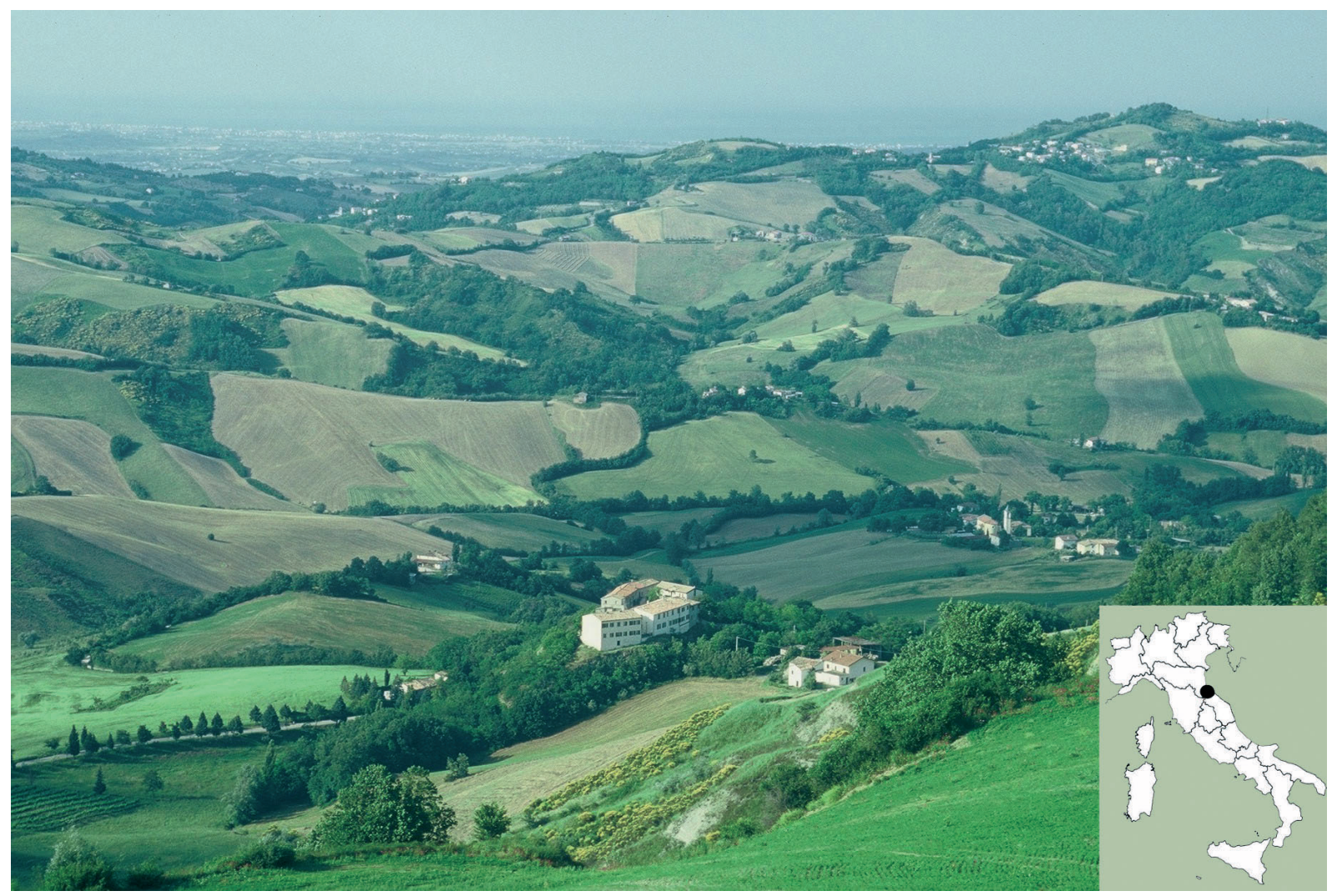

Figure 1: The study area.

Slika 1: Raziskovano območje. 


\section{THE STUDY AREA}

The Onferno Nature Reserve is located in the hilly subcoastal territories of the province of Rimini, on the border with the Marche Region (Figure 1). According to the biogeographical classification of Rivas-Martínez (Rivas-Martínez et al. 2004), the territory is part of the Eurosiberian Region, Alpino-Caucasic Subregion, Apennine-Balkan Province, Apennine Subprovince.

The bioclimate was evaluated on the basis of data from the meteorological station of the nearby San Marino (Figure 2) and it is an oceanic temperate macrobioclimate (submediterranean variant), of an upper mesotemperate thermotype, and lower subhumid ombrotype (Rivas-Martínez 2008).

With regard to its geology, the area is characterized by early Pliocene native soils (loam and clay), upon which the clay layer of Val Marecchia has overlapped, with the gypsum blocks moved to its centre. The Messinian gypsum and clays of the allochthonous layer discontinuously cover the sedimentary deposits of the Pliocene age; the main gypsum outcrop is the visible part of a large block of gray selenitic gypsum of the Lower Messinian, arising from the Val Marecchia series (Ruggieri 1958; Bertolani \& Rossi 1997; Lucchi \& Scaravelli 2005). Further new sedimentation then led to the formation of the sandstone and marl of the middle Pliocene, the final phase of the sedimentation (Lucchi \& Scaravelli 2005).

\section{MATERIALS AND METHODS}

\subsection{AnAlisi della vegetazione}

To describe the main types of vegetation, 120 phytosociological relevés were carried out in different areas of the Reserve. The cluster analysis was performed by means of the software SYNTAX 2000 (Podani 2001), using complete link and similarity ratio coefficient on the phytosociological data (woods and vegetation of grasslands and badlands), converted according to the ordinal scale proposed by van der Maarel (1979). The study of the dynamic relationships between the different vegetation associations allowed the identification of the vegetation series of the different geomorphological units (geosigmeta) and the description of the landscape of the Onferno Nature Reserve.

The analysis of the vegetation was carried out according to the phytosociological method of the Sigmatist School of Braun-Blanquet, as more recently updated according to the integrated Phytosociological School of Rivas-Martínez (BraunBlanquet 1964; Tüxen, 1956, 1977, 1979; Biondi 1994, 1996; Gehu \& Rivas-Martínez 1981, RivasMartínez 2005a, b). All of the data were analyzed by GIS, and the map of the vegetation series was constructed.

For the species nomenclature, in terms of the biological forms and the chorological types, reference was made to "Flora d'Italia" (Pignatti

\section{RIMINI

$\begin{array}{lllll}\mathrm{P}=688 & 44^{\circ} 01^{\prime} \mathrm{N} & 012^{\circ} 36^{\prime} \mathrm{E} & 11 / 11 \mathrm{y} . & \text { TEMPERATE OCEANIC (SUBMEDITERRANEAN) } \\ \mathrm{T}=13 & \mathrm{I}=19.2 & \mathrm{~T} \mathrm{p}=1590 & \mathrm{~T} n=0 & \text { UPPER MESOTEMPERATE } \\ \mathrm{m}=0.0 & \mathrm{M}=7.2 & \mathrm{Itc}=211 & \mathrm{l} 0=4.3 & \text { LOWER MESOTEMPERATE }\end{array}$

$M^{\prime}=39.4$
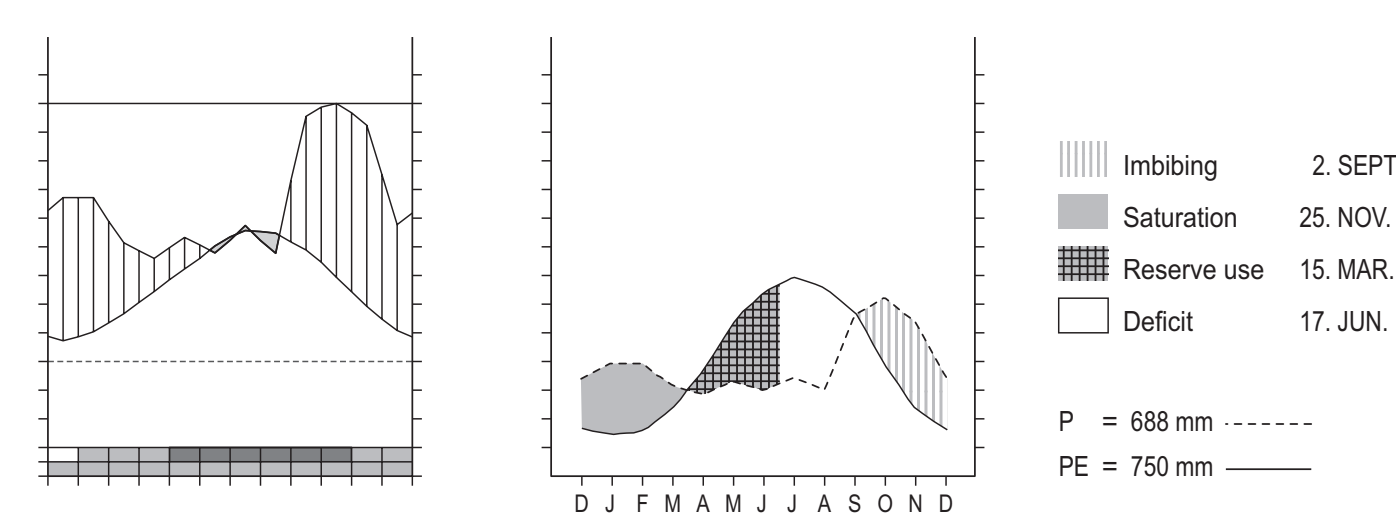

$m^{\prime}=-10.6$

Figure 2: Pluviothermic diagram.

Slika 2: Pluviotermični diagram. 
1982), "Flora Europaea" (Tutin et al. 1964-80, 1993) and the "Checklist of the Italian Vascular Flora" (Conti et al. 2005). For the syntaxonomic classifications of the vegetational typologies, reference was made to the European literature (Oberdorfer 1994; Rivas-Martínez et al. 2002a, $2002 \mathrm{~b}$ ) and to studies of the Italian vegetation, and the Apennine vegetation in particular (Ferrari 1971; Ferrari \& Speranza 1975; Biondi et al. 1986, 1988, 1995, 2001, 2002, 2003, 2006; Pirone 1995; Allegrezza et al. 2002; Poldini et al. 2002; Blasi et al. 2004; Taffetani et al. 2004, 2005, 2009; Gubellini \& Zitti 2010).

\subsection{Conservation of SEcondary GRASSLANDS: EXPERIMENTAL ACTIVITIES.}

To evaluate the sustainability in economic management terms and the effectiveness of the reintroduction of grazing animals to maintain the quality of the grasslands, two donkeys and three sheep were kept in a portion (approximately $3 \mathrm{ha}$ ) of a selected Bromus erectus grasslands for a period of 165 days. Given the absence of any real propensity of the local farms towards livestock breeding and the difficulty of finding and managing grazing animals, the experimental work was carried out with a different number and combinations of animals than those evaluated as optimal in the design phase (Bagella 2001).

The application of ecological indicators for the evaluation of the environmental quality of the agro-ecosystems (Taffetani \& Rismondo 2009; Rismondo et al. 2011) has allowed us to highlight some differences in terms of the dynamic evolution of the vegetation of the grasslands, particularly in relation to their management (grazing) and to their substrata. The floristic-vegetational indices used for application to the case study are the maturity index (MI), which can measure the evolutionary value of a plant community, the index of floristic biodiversity (IFB), which is calculated on the basis of species present in the fitosociological relevés, and the indices of the biological forms (IT, therophytes; IH, hemicryptophytes; IF, perennial non-hemicryprophytes), with which it is possible to evaluate the percentage incidence of hemicryptophyte species (IH) within a plant coenosis.

\section{RESULTS}

\subsection{Vegetation}

The Multivariate analysis applied separately to the table of forest relevés and grassland relevés allowed to group the relevés in clusters corresponding to the main vegetation types, as shown by the two dendrograms in figures 3 and 4 .

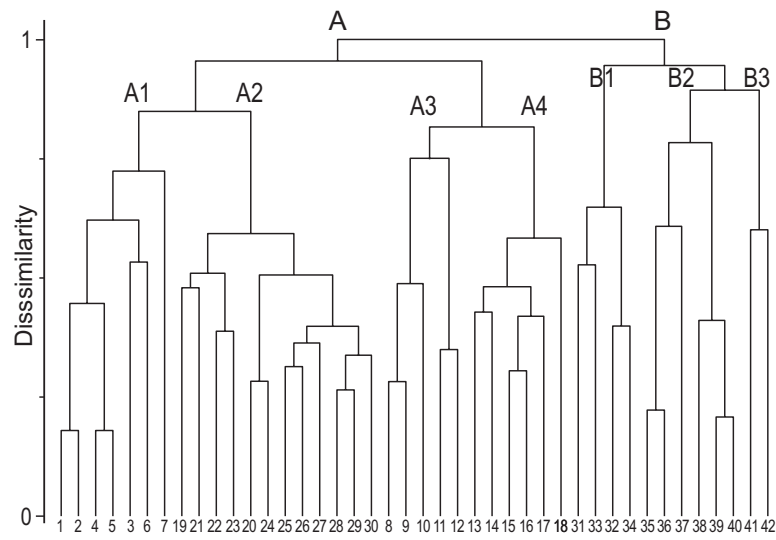

Figure 3: Cluster analysis: dendrogram of woods of Onferno Nature Reserve. Cluster A: Querco-Fagetea (A1: Aceretum obtusati-pseudoplatani; A2: Asparago acutifolii-Ostryetum carpinifoliae; A3: Roso sempervirentis-Quercetum pubescentis; A4: Ruscus aculeatus variant of Roso sempervirentis-Quercetum pubescentis association). Cluster B: Salici purpureaePopuletea nigrae (B1: Symphyto bulbosi-Ulmetum minoris; B2: Salicetum apenninae; B3: Salicetum albae).

Slika 3: Klastrska analiza: dendrogram gozdov naravnega rezervata Onferno. Klaster A: Querco-Fagetea (A1: Aceretum obtusati-pseudoplatani; A2: Asparago acutifolii-Ostryetum carpinifoliae; A3: Roso sempervirentis-Quercetum pubescentis; A4: Ruscus aculeatus varianta asociacije Roso sempervirentisQuercetum pubescentis). Klaster B: Salici purpureae-Populetea nigrae (B1: Symphyto bulbosi-Ulmetum minoris; B2: Salicetum apenninae; B3: Salicetum albae).

The dendrogram of woods relevés (Figure 3) shows two main clusters (A and B): cluster A includes the woods of Querco-Fagetea with association Aceretum obtusati-pseudoplatani of Fagetalia order (A1); the association Asparago acutifolii-Ostryetum carpinifoliae (A2) and the association Roso sempervirentis-Quercetum pubescentis (A3) with the Ruscus aculeatus variant (A4) of Quercetalia order. Cluster B includes Salici-Populetea woods with: association Symphyto bulbosi-Ulmetum minoris (B1); association Salicetum apenninae (B2) and association Salicetum albae (B3). The dendrogram of Figure 4 shows three main clusters $(\mathrm{A}, \mathrm{B}, \mathrm{C})$ : cluster $\mathrm{A}$ includes 


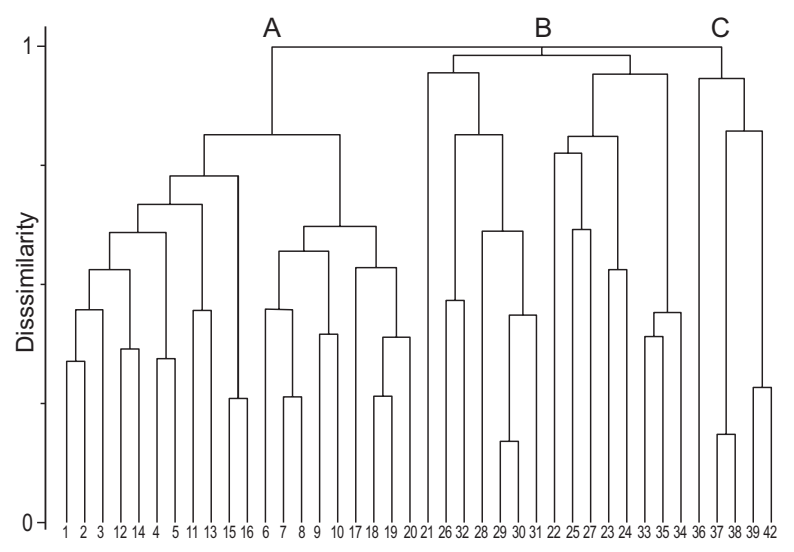

Figure 4: Cluster analysis: dendrogram of grasslands and badlands of Onferno Nature Reserve. Cluster A: FestucoBrometea class; cluster B: Artemisietea class; cluster C: Helianthemetea guttati class with new association Vicio variaeHainardetum cylindricae.

Slika 4: Klastrska analiza: dendrogram travišč in ruderalnih površin naravnega rezervata Onferno. Klaster A: razred Festuco-Brometea; klaster B: razred Artemisietea; klaster C: razred Helianthemetea guttati $\mathrm{z}$ novo asociacijo Vicio variaeHainardetum cylindricae.

grassland relevés of Festuco-Brometea class; cluster $\mathrm{B}$ includes vegetation of badlands of Artemisietea class with the association Agropyro-Asteretum linosyridis; cluster C includes Vicio variae-Hainardetum cylindricae of Helianthemetea guttati class.

\subsubsection{Woods}

Aceretum obtusati-pseudoplatani Biondi, Casavecchia, Pinzi, Allegrezza \& Baldoni 2002 staphyletosum pinnati subass. nova hoc loco (Holotypus rel. 6, Table. 1).

From the naturalistic point of view, the most interesting forest coenosis is definitely represented by forests of large-leaved linden (Tilia platyphyllos) that grow in the chalky ravine that overlooks the entrance to the karst caves inside the underground complex. Fresh, moist air escapes from the caves, which results in local thermal inversion in summer. This sets up a cool and moist microclimate, to which the northern exposure of the cut also contributes.

The linden forests are mainly of a relict form at the base of the east alpine valleys, and they become increasingly more fragmented and scattered moving toward the western alpine mountain area along the Apennine chain. There have been few reports on this type of forest (Taffetani
2000, Biondi et al. 2002; Allegrezza 2003; Catorci et al. 2003; Taffetani et al. 2004; Angiolini et al. 2005).

This linden coenosis of Onferno differs from similar coenoses of the Apennine limestone (Biondi et al. 2002; Taffetani et al. 2004), for its modest altitude, the separation from the Apennine peaks, and the proximity to the Adriatic coast. In addition to the unique ecological and biogeographical characteristics of the study site, the floral composition allows the linden forest of Onferno to be included in the new subassociation, staphyletosum pinnate, characterized by the constant and abundant presence of Tilia platyphyllos and Staphylaea pinnnata, while there is a lack of Ulmus glabra and some characteristic species of the association (Corydalis cava, Asperula taurina, Glechoma hirsuta and Cardamine enneaphyllos). For the differential species of the new subassociation, as well as Staphylaea pinnnata, there are species that are particularly rare across the Apennines due to the ravine forest and its rocky soil. These include Loncomelos pyrenaicus, a geophyte of mesophilous forest environments of Apennine ravines, Phyllitis scolopendrium, a fern closely linked to moist, rocky areas with little light, and Asparagus acutifolius and Lonicera etrusca, the presence of which is an indicator of the climatic influence of the proximity to the sea, Lamiastrum galeobdolon ed Aegopodium podagraria.

In the territory of the Reserve, this formation is strictly limited to the gypsum substrata that emerge within the deep incision, which is overlooked by the entrances to the caves. The small size of this forest ecosystem means that the microclimate created within the gorge, and in particular along its base, is strongly limited and influenced by the external environmental conditions, which are characterized by cultivated clay soils. Consequently, the evident floristic diversity and originality of this forest ecosystem is limited.

\section{Roso sempervirentis-Quercetum pubescentis Biondi} 1986 (Table 2)

The forest of downy oak that is attributed to the association Roso sempervirentis-Quercetum pubescentis has grown in the territory of the Reserve under arid edaphic conditions, on compact sandstone substrata and on gypsum substrata. Fraxinus ornus, Prunus avium, Cornus mas, Acer campestre and Quercus cerris contribute to the composition of the tree stratum. On the sandstone substrata, the association is seen in its typi- 
cal aspect, while on the gypsum substrata, for the outcropping summit areas where the soil layer is thinner, the variant of Ruscus aculeatus of the association has developed. This last core forest that grows near to Onferno Castle is characterized by a thinner forest cover and by a more pronounced Mediterranean character, as compared to similar coenoses in the territory, as indicated by the presence of species of the suballiance Lauro nobilisQuercenion pubescentis.

Asparago acutifolii-Ostryetum carpinifoliae Biondi 1982 (Table 3)

The forest of Selve has developed on the marly-sandstone outcrops that form the upper part of the relief that runs along the southern boundary of the Reserve. These marly-sandstone outcrops are subjected to intense erosion because of the collapse caused by the active badlands below them. They have a relatively irregular morphology due to the alternation of flat or slightly uneven surfaces and valley cuts, and sometimes they are closed and shadowy. This leads to some variability of forest types, due to the concentration of thermoxerophilous species on the flatter morphology, and of mesohygrophilous species along the fall lines. The outcropping of the underlying clay substrate results in more moist substrata and provides the right conditions for development of the hop hornbeam (Ostrya carpinifolia), which accounts for the scarcity or absence of some species that have a clear Mediterranean character, such as Smilax aspera, Rubia peregrina and Laurus nobilis.

\section{Symphyto bulbosi-Ulmetum minoris Biondi \& Alle-} grezza 1996 (Table 4)

Small nuclei of Ulmus minor woods are found on the clay substrata, where the confluence of the run-off of the surface water promotes the establishment of edaphohygrophilous species, such as Ulmus minor, Sambucus nigra, Populus nigra, Salix alba, Salix apennina, Arum italicum and Agrostis stolonifera, among others.

The limited size of these forest nuclei accounts for the wide presence of shrub species of the class Rhamno-Prunetea.

\section{Salicetum apenninae Pedrotti, Spada \& Conti} 1996 (Table 5)

In the badland systems, where the surface run-off water collect, there are more or less extensive formations with a dominance of willow and other hygrophilous species. In areas with steeper slopes, and hence on the higher parts of the badlands, the dominant species is Salix apennina. The variant of Milium effusum identifies the places where there is more water, which occur at the base of the badland.

\section{Salicetum albae Issler 1926 (Table 6)}

In the flatter areas along the fall lines of the badlands where the water remains longer, and where there is an actual stream of water, there are formations dominated by Salix alba. This coenosis is also found along the banks of the water course at the bottom of the main chalky ravine.

\subsubsection{The undergrowth and shrubs}

\section{$\underline{\text { Rubo ulmifolii-Ligustretum vulgare Poldini } 1989}$ (Table 7)}

At the edge of the linden wood, with a relatively cool microclimate, there is a shrub layer that includes: Cornus sanguinea, Ligustrum vulgare, Crataegus monogyna, Prunus spinosa and Rubus ulmifolius.

\section{Spartiojuncei-Cytisetum sessilifolii Biondi, Alle- grezza \& Guitian 1988}

In contact with thermophilous forests of the clay and marly-sandstone substrata, the shrub layer that has developed is dominated by Spartium junceum, with many Mediterranean species, described by the association Spartio juncei-Cytisetum sessilifolii.

\subsubsection{Vegetation of the grass edges and the grasslands}

\section{Carex flacca community (Table 8 )}

At the edges of the downy oak forest (Roso sempervirentis-Quercetum pubescentis) and the hop hornbeam forest (Asparagus acutifolii-Ostryetum carpinifoliae), in areas of transition between the forest coenoses and the grasslands or the cultivated fields, there is herbaceous vegetation that is dominated by Carex flacca, which is attributed to the class Trifolio-Geranietea, which also includes many species of the classes Molinio-Arrenatheretea and Artemisietea.

\section{Agrostis stolonifera community (Table 8)}

This community is characterized by Agrostis 
stolonifera, Poa pratensis and Aristolochia rotunda, and it is the edge vegetation of the elm forest described for the association Symphyto bulbosi-Ulmetum minoris that grows along the fall lines on clay substrata.

\section{Geum urbanum community (Table 9)}

At the edges of the linden wood on the gypsum substrata, and under conditions of strong shading, edaphic humidity, and low temperatures, there is a narrow strip of herbaceous vegetation with a dominance of Geum urbanum and Buglossoides purpurocaerulea, included in the class Galio-Urticetea.

\section{Ballota nigra community (Table 10)}

Again on the gypsum substrata but under edaphoxerophilous conditions, in contact with the downy oak wood near Onferno Castle, there is a nitrophilous vegetation with a dominance of Ballota nigra, included in the class Galio-Urticetea. As well as the important presence of species of the class Galio-Urticetea, such as Urtica dioica ssp. dioica, Geum urbanum and Alliaria petiolata, there is a significant presence of species of the class Artemisietea, such as Artemisia vulgaris, Daucus carota, Carduus pycnocephalus ssp. pycnocephalus and Picris hieracioides, among others.

\section{Centaureo bracteatae-Brometum erecti Biondi,}

Ballelli, Allegrezza, Guitian \& Taffetani 1986

\section{(Table 11)}

The grasslands in the area are all of human origins, and are therefore strictly dependent on the maintenance of livestock activities for their conservation. The most extensive grasslands have developed on the sandstone substrata in the southwestern sector of the Reserve. These are a semimesophilous coenosis with a dominance of Bromus erectus with Centaurea jacea ssp. weldeniana, Galium mollugo ssp. erectum, Centaurea scabiosa, Brachypodium rupestre, Lotus corniculatus, Anacamptis pyramidalis, Gymnadenia conopsea and Cephalanthera longifolia, among others. Part of this area was cultivated until fairly recently, as can be seen by the presence of species of the class Molinio-Arrhenatheretea. From the chorological point of view, a clear dominance can be seen for Eurasian elements, also if there are substantial Mediterranean elements. Under the more edaphoxerophilous conditions, the coenoses are enriched mainly in Mediterranean species, which describe the variant of Asperula purpurea, such as Teucrium chamaedrys, Asperula purpurea, Helichrysum italicum, Eryngium amethystinum and Ononis pusilla. Along the tops of the badlands on the clay substrata, the pastures are restricted to small areas where a certain degree of stability has been created: these coenoses are identified by the variant of Elymus repens ssp. repens, along with which there are also Tussilago farfara and Festuca pratensis.

\subsubsection{Vegetation of the badlands}

\section{Agropyro-Asteretum linosyridis Ferrari $1971 \mathrm{em}$. Ferrari 1975 (Table 12)}

In the sectors with the outcrops of the clay substrata that have resulted from the formation of a system that has undergone rapid erosion there is the characteristic landscape of the badlands. These are systems of relatively deep valleys that are carved out by water, with the individual cuts separated from each other by thin buttresses. These badland structures are found relatively frequently along all of the Adriatic coast, from Romagna down to Molise, and they have a fairly common floristic cortége, the variations of which are almost exclusively related to the content of sodium and potassium salts; the badlands of the Onferno Reserve are made of clay with a low salt content. Indeed, the association is described by perennial pioneer communities of slightly salty environments, as indicated by the presence of Elymus athericus, a sub-halophyte species, and by the absence of salt-tolerant species. The association is included in suballiance Podospermo laciniati-Elytrigenion athericae, of the alliance Inulo viscosae-Agropyrion repentis (Biondi \& Pesaresi 2004).

Here, it is possible to distinguish three aspects of this vegetation type:

- Communities that are found at the base of the badland structures where the landslips result in the accumulation of clay soil from the walls above or from the tops of the badlands adjacent to the cultivated fields. In these communities, there are many species of the order Agropyretalia, which is typical of more or less recent post-cultivation situations, and species of the class Stellarietea mediae, due to the influence of the adjacent cultivated fields. This vegetation is included in the association Agropyro-Asteretum linosyridis (Table 12, Rel. 1-7). 
- Communities that have become established at the base of the badlands where water accumulates. Here, the presence of Elymus athericus is associated with relatively high cover of $E q$ uisetum telmateja, Holcus lanatus and Lathyrus pratensis. These communities are described by the variant of Equisetum telmateja of the association Agropyro-Asteretum linosyridis (Table 12, Rel. 8-12).

- Communities with few species that develop in the areas of erosion, which are bare and hard, and where there is a relatively higher concentration of salt. These communities can be identified by the variant of Scorzonera jacquiniana, which represents the most pioneer aspect. This vegetation type is not described by the association Podospermo canae-Plataginetum maritimae that was described for Sasso Simone and Simoncello, in upper Montefeltro (Biondi et al. 1986), because the present vegetation describes a situation of greater salinity, as can be seen by the presence of Plantago maritima (Table 12 Rel. 15-17).

Vicio variae-Hainardetum cylindricae ass. nova hoc loco (Holotypus rel. 2, Table 13)

We describe the new association Vicio variaeHainardetum cylindricae for the annual pioneer vegetation that grows on the clayey substrata under conditions of thin and compacted soil. Given the low salt content of these clays, compared to similar situations in the Apennines (Biondi et al. 1996), clearly alophilous species such as Agropyron pungens and Salsola soda are absent, while there is a significant presence of annual terophytes that classifies this type of vegetation in the class Helianthemetea guttata (not in the class Saginetea maritimae, which includes the association Hainardo cylindricae-Salsoletum sodae, of alo-sub-nitrophilous conditions). Moreover, there is a relevant presence of species of the class Artemisietea vulgaris. The characteristic species of the new association are Hainardia cylindrica, Vicia villosa ssp. varia, Bromus hordeaceus and Scorzonera laciniata.

Arundinetum plinianae Biondi, Brugiapaglia, Allegrezza \& Ballelli 1992 (Table 14)

At the base of the slopes of the badlands, there are dense formations of Pliny's reed (Arundo pliniana), in which as well as species of the class Artemisietea, there are also many species of the class Rhamno-Prunetea, such as Spartium junceum, Prunus spinosa, Rosa canina and Rubus ulmifolius.

\subsubsection{Chasmophytic vegetation}

Alysso alyssoidis-Sedetum albi Oberd. et Th. Muell. in Th. Muell. 61 (Table 15)

On the sunny chalky cliffs, where there is a thin layer of soil, small populations of plants have settled, dominated by the succulents Sedum album and Sedum dasyphyllum; which are included in the class Sedo-Scleranthetea. There are also therophytes with Mediterranean tendencies, like Medicago minima, Cerastium semidecandrum, Campanula erinus and Hypochoeris achyrophorus, and species of the classes Stellarietea mediae and Artemisietea vulgaris, which indicate the contact with man-made environments.

\subsubsection{Commensal crop vegetation}

\section{Linario spuriae-Stachyetum annuae Lorenzoni} 1965 (Table 16)

Most of the cultivated areas are on clay substrata. The commensal vegetation of these cultivated fields has been included in the association Linario spuriae-Stachyetum annuae, of the order Solano nigri-Polygonetalia convolvuli, and the alliance Polygono-Chenopodion polyspermi.

\section{Biforo testiculatae-Adonidetum cupanianae Kropáč} 1982 (Table 17)

This association describes the commensal vegetation of the fields on sandstone substrata; these are included in the order Centaureetalia cyani and in the alliance Caucalidion lappulae.

\subsubsection{Syntaxonomic scheme}

QUERCO-FAGETEA Br.-Bl. \& Vlieger in Vlieger 1937

+ Fagetalia sylvaticae Pawlowski in Pawlowski, Sokolowski \& Wallisch 1928

- Tilio platyphylli-Acerion pseudoplatani Klika 1955 Aceretum obtusati-pseudoplatani Biondi, Casavecchia, Pinzi, Allegrezza \& Baldoni 2002 staphyletosum pinnati subass.nova

+Quercetalia pubescenti-petraeae Klika 1933

- Carpinion orientalis Horvat 1958

* Lauro nobilis-Quercenion pubescentis Ubaldi (1988) 1995

Asparago acutifolii-Ostryetum carpinifoliae Biondi ex Ubaldi 1995 
Roso sempervirentis-Quercetum pubescentis Biondi 1986 Ruscus aculeatus variant

SALICI PURPUREAE-POPULETEA NIGRAE (Rivas-Martínez \& Cantó ex Rivas-Martínez, Báscones, T.E. Díaz, Fernández-González \& Loidi 1991) Rivas-Martínez, T.E. Díaz, Fernández-González, Izco, Loidi, Lousã \& Penas 2001

+ Salicetalia purpureae Moor 1958

- Salicion albae Soó 1930 em Moor 1958

Salicetum albae Issler 1926

- Salicion eleagni Aichinger 1933 nom. mut. propos. Rivas-Martínez, Diaz, Fernandez Gonzalez, Izco, Loidi, Lousa \& Penas 2002

Salicetum apenninae Pedrotti, Spada \& Conti 1996 Milium effusum variant

- Alnion incanae Pawlowski in Pawlowski, Sokolowski \& Wallisch 1928

Symphyto bulbosi-Ulmetum minoris Biondi \& Allegrezza 1996

RHAMNO-PRUNETEA Rivas Goday et Boria Carbonell ex Tüxen 1962

+ Prunetalia spinosae R. Tx. 1952

- Cytision sessilifolii Biondi 1988

Spartio juncei-Cytisetum sessilifolii Biondi in Biondi, Allegrezza et Guitian 1988

- Berberidion vulgaris Br.-Bl. 1950

* Fraxino orni-Berberidenion Poldini \& Vidali 1995 Rubo ulmifolii-Ligustretum vulgare Poldini 1989

GALIO-URTICETEA Passarge ex Kopecky 1969

+ Galio aparines-Alliarietalia petiolatae Görs \& Müller 1969.

- Galio-Alliarion petiolatae Oberdorfer \& Lohmeyer in Oberdorfer, Görs, Korneck, Lohmeyer, Müller, Philippi \& Seibert 1967

Geum urbanum community

Ballota nigra community

\section{TRIFOLIO MEDII-GERANIETEA SANGUINEI} Müller 1962

+ Origanetalia vulgaris Müller 1962

- Geranion sanguinei Tüxen in Müller 1962

Carex flacca community

Agrostis stolonifera community

FESTUCO-BROMETEA Br.-Bl. \& Tüxen ex Br.-Bl. 1949

+ Brometalia erecti Br.-Bl. 1936

++ Leucanthemo vulgaris-Bromenalia erecti Biondi, Ballelli, Allegrezza \& Zuccarello 1995

- Bromion erecti Koch 1926
* Polygalo mediterraneae-Bromenion erecti Biondi, Allegrezza \& Zuccarello 2005

Centaureo bracteatae-Brometum erecti Biondi, Ballelli, Allegrezza, Guitian \& Taffetani 1986

Agropyron repens variant

Asperula purpurea variant

SEDO-SCLERANTHETEA Br.-Bl. 1955 em. Th. Müller 1961

+ Sedo-Scleranthetalia Br.-Bl. 1955

- Alysso alyssoidis-Sedion albi Oberdorfer \& Müller in Müller 1961

Alysso alyssoidis-Sedetum albi Oberd. et Th. Muell. in Th. Muell. 61

HELIANTHEMETEA GUTTATI (Br.-Bl. in Br.-Bl., Roussine et Nègre 1952) Rivas Goday et RivasMartínez 1963 em. Rivas-Martínez 1978

+ Helianthemetalia guttati Br.-Bl. in Br.-Bl., Molinier \& Wagner 1940 em. Rivas-Martínez 1978

- Helianthemion guttati Br.-Bl. in Br.-Bl., Molinier \& Wagner 1940

Vicio variae-Hainardetum cylindricae ass. nova

ARTEMISIETEA VULGARIS Lohmeyer, Preising \& Tüxen ex von Rochow 1951

+ Agropyretalia repentis Oberdorfer, Müller \& Görs in Oberdorfer, Görs, Korneck,Lohmeyer, Müller, Philippi \& Seibert 1967

- Inulo viscosae-Agropyrion repentis Biondi \& Allegrezza 1996

* Inulo viscosae-Agropyrenion repentis

Arundinetum plinianae Biondi, Brugiapaglia, Allegrezza \& Ballelli 1992

* Podospermo laciniati-Elytrigenion athericae (Pirone 1995) stat. nov. Biondi \& Pesaresi 2004

Agropyro-Asteretum linosyridis Ferrari $1971 \mathrm{em}$. Ferrari 1975

Equisetum telmateja variant

Scorzonera jaquiniana variant

STELLARIETEA MEDIAE Tüxen, Lohmeyer \& Preising ex von Rochow 1951

+ Solano nigri-Polygonetalia convolvuli (Sissingh in Westhoff, Dijk \& Passchier 1946) Bolòs 1962

- Polygono-Chenopodion polyspermi Koch 1926

Linario spuriae-Stachyetum annuae Lorenzoni 1965

+ Centaureetalia cyani Tüxen ex von Rochow 1951

- Caucalidion lappulae Tüxen ex von Rochow 1951 Biforo testiculatae-Adonidetum cupanianae Koprác 1982

Scandix pecten-veneris variant 


\subsection{Plant Landscape AND MaP OF VEGETATION SERIES}

Based on its geomorphological characteristics, the territory of the Onferno Reserve can be divided into three main landscape systems: geosigmetum of gypsum substrata, geosigmetum of compact sandstone substrata and geosigmetum of clay substrata. The alternation of these three main geomorphological units creates a mosaic of environments in which the nuclei of the clearly Mediterranean vegetation typologies are spatially very close to the nuclei of the strongly mesophilous vegetation also of central European environments.

Within each landscape system, the series of potential vegetation have been reconstructed through the study of the various phytocoenoses present in the territory and the strips of plants that have survived the intense human activities, which have been typically related to the hilly and plain areas.

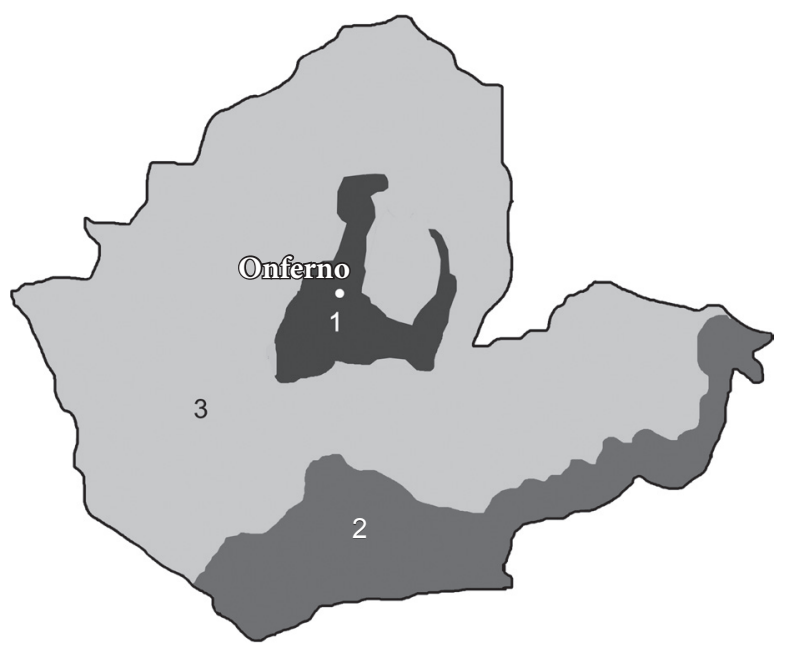

1 Landscape Unit of Gypsum substrata

2 Landscape Unit of Sandstone substrata

3 Landscape Unit of Clay substrata

Figure 5: Outline of the three geomorphological units. Figure 5: Meje treh geomorfoloških enot.

\subsubsection{Landscape unit of the gypsum substrata}

Two dynamic vegetation series have been identified on the gypsum substrata: in the main ravines, under the cool and damp microclimate conditions, the climatophilous series has developed, for which the mature stage is represented by the linden woods (Aceretum obtusati-pseudoplatani staphyletosum pinnatae); while at the tops of the gypsum outcrops, the particularly dry edaphic conditions that arise from the high permeability of the gypsum substrata, have led to the formation of an edaphoxerophilous series where the climax stage is represented by the downy oak (Roso-Quercetum sempervirentis pubescentis, as the variant with Ruscus aculeatus).

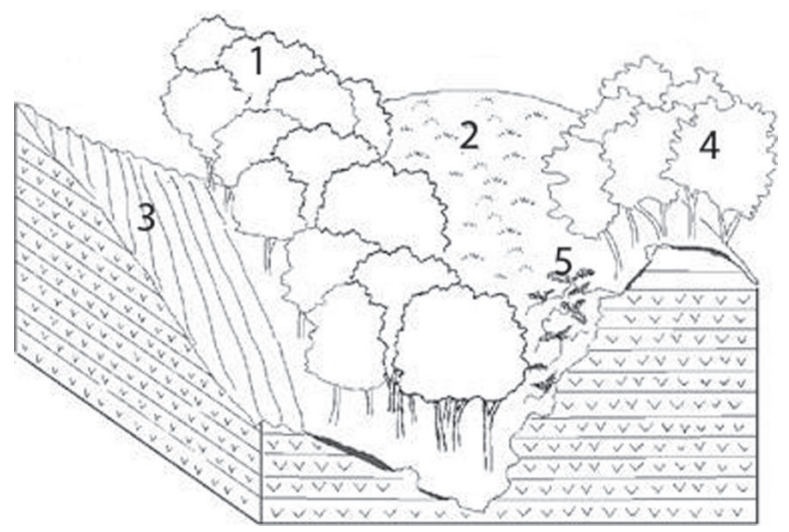

Figure 6: Landscape unit of the gypsum substrata. Climatophilous series of linden: 1 . Mesophilous woods of the gypsum gorges with a dominance of linden (Aceretum obtusatipseudoplatani, staphyletosum pinnati); 2. Abandoned fields; 3. Fields with invading vegetation (Biforo testiculatae-Adonidetum cupanianae). Edaphoxerofilous series of the downy oak: 4. Deciduous woods of the tops of the gypsum ridges with a dominance of downy oak (Roso sempervirentis-Quercetum pubescentis, variant of Ruscus aculeatus); 5. Pioneer cliff formations of the shaded gypsum walls with a dominance of Polypodium cambricum ssp. serrulatum.

Figure 6: Krajinska enota na gipsu. Klimatofilna serija javorja: 1. Mezofilni gozdovi v soteskah $\mathrm{v}$ gipsu $\mathrm{z}$ prevladujočim javorjem (Aceretum obtusati-pseudoplatani, staphyletosum pinnati); 2. Opuščena polja; 3. Polja, ki jih obrašča vegetacija (Biforo testiculatae-Adonidetum cupanianae). Edafokserofilna serija puhastega hrasta: 4 . Listopadni gozdovi na vrhu slemen gipsa s prevladujočim puhastim hrastom (Roso sempervirentis-Quercetum pubescentis, variant z Ruscus aculeatus); 5. Pionirske klifske formacije na zasenčenih stenah iz gipsa s prevladujočo vrsto Polypodium cambricum ssp. serrulatum.

\subsubsection{Landscape unit of the compact sandstone substrata (Formation Montecalvo in Foglia)}

This landscape unit is found in the southern sector of the Reserve and represents the top layer of the clay ridges. Also in this environmental system there are two series of vegetation: a climatophilous series, where the more mature stage is represented by a forest of Ostrya carpinifolia (Asparagus acutifolii-Ostryetum 
A

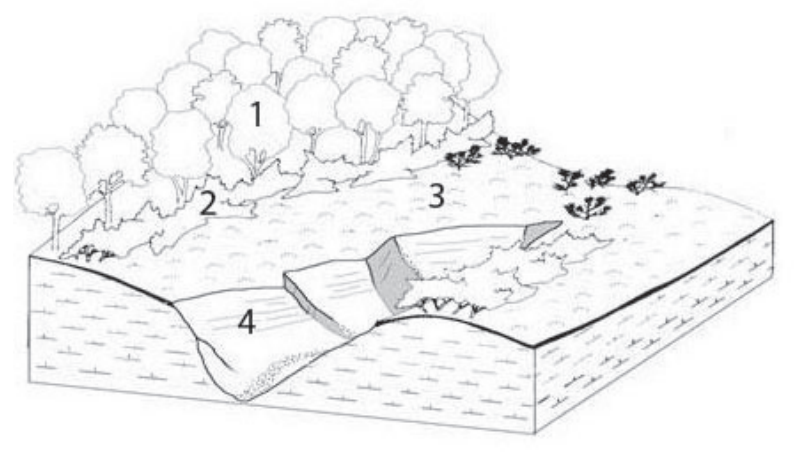

B

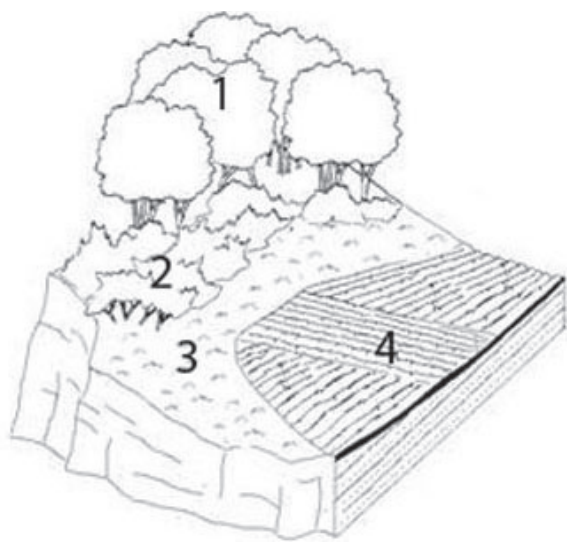

Figure 7: Landscape unit of the sandstone substrata. Climatophilous series (A) 1. Hop hornbeam wood (Asparago acutifoliiOstryetum carpinifoliae); 2. Grouping of Cornus sanguinea; 3. Semimesophilous grasslands (Centaureo bracteatae-Brometum erecti); 4) Badlands. Edaphoxerophilous series of the sandstone (B): 1. Downy oak wood (Roso sempervirentis-Quercetum pubescentis); 2. Grouping of elmleaf blackberry (Rubus ulmifolius); 3. Semimesophilous grasslands (Centaureo bracteatae-Brometum erecti); 4. Cutivated fields with invading vegetation (Biforo testiculatae-Adonidetum cupanianae).

Slika 7: Krajinska enota na peščenjaku: Klimatofilna serija (A) 1. Gozdovi črnega gabra (Asparago acutifolii-Ostryetum carpinifoliae); 2. Grmišča vrste Cornus sanguinea; 3 . Mezofilna travišča (Centaureo bracteatae-Brometum erecti); 4) Ruderalne površine. Edafokserofilna serija na peščenjaku (B): 1. Gozdovi puhastega hrasta (Roso sempervirentis-Quercetum pubescentis); 2. Grmišča brestovolistne robide (Rubus ulmifolius); 3. Mezofilna travišča (Centaureo bracteatae-Brometum erecti); 4. Obdelana polja, ki jih postopoma zarašča vegetacija (Biforo testiculatae-Adonidetum cupanianae).
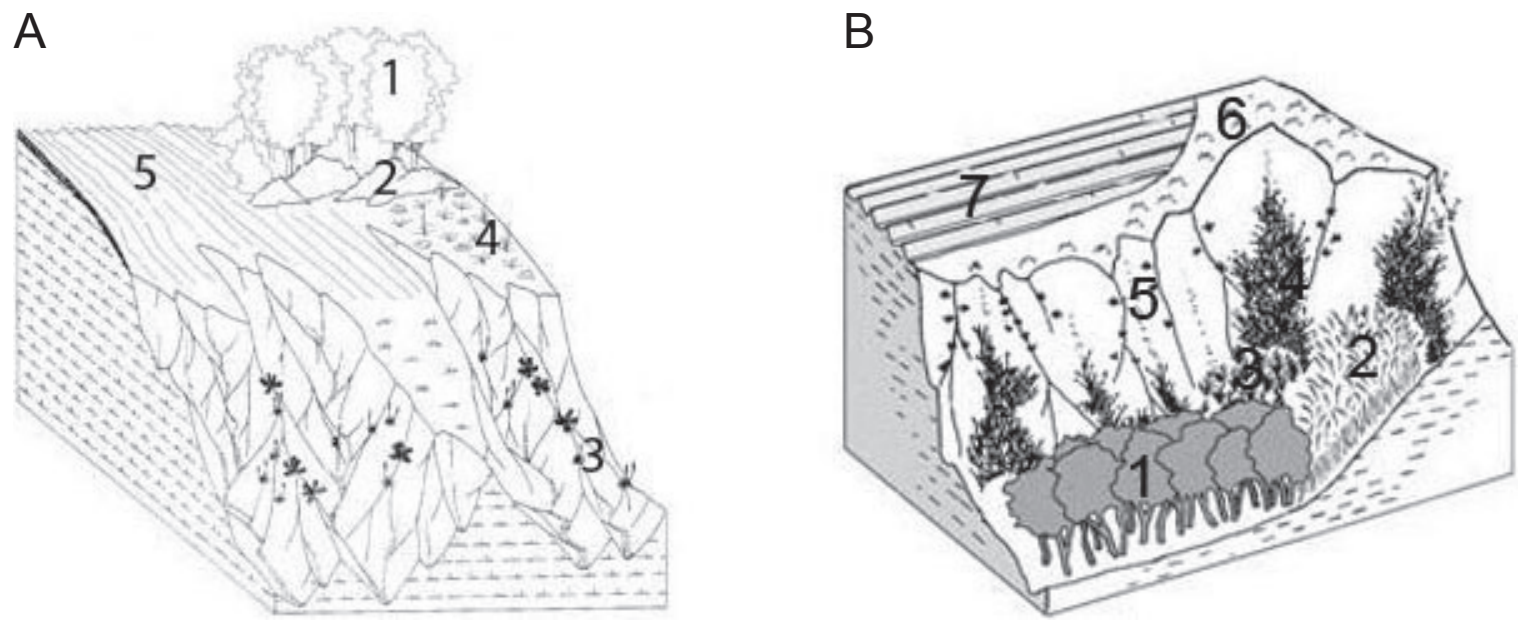

Figure 8: Landscape unit of the clay substrata. Climatophilous series of the downy oak (A): 1. Deciduous woody strips with a dominance of downy oak (grouping of Quercus pubescens); 2. Shrub layer arising from the abandonment of cultivation and livestock practices (grouping of Spartium junceum); 3. Badland complexes; 4. Abandoned fields (Senecio erucifolii-Inuletum viscosae); 5. Cultivated fields with invading vegetation (Linario spuriae-Stachyetum annuae). Edaphohygrophilous series of the clay (B): 1. Nuclei of elm wood (Symphyto bulbosi-Ulmetum minoris); 2. Formations of Pliny's reed (Arundinetum plinianae); 3. Salicetum albae; 4. Salicetum apenninae; 5. Badland complexes; 6. Neobdelani zeliščni robovi; 7. Cultivated fields with invading vegetation (Linario spuriae-Stachyetum annuae).

Slika 8: Krajinska enota na glini. Klimatofilna serija s puhastim hrastom (A): 1. Listopadni gozdni pasovi s prevladujočim puhastim hrastom (skupine s Quercus pubescens); 2. Grmišča na opuščenih odelanih in pašenih površinah (skupine s Spartium junceum); 3. Ruderalne površine; 4. Opuščena polja (Senecio erucifolii-Inuletum viscosae); 5. Obdelana polja, ki se postopoma zarašča vegetacija (Linario spuriae-Stachyetum annuae). Edafohigrofilna serija na glini (B): 1. Nukleusi brestovega gozda (Symphyto bulbosi-Ulmetum minoris); 2. Formacije Plinijevega trsta (Arundinetum plinianae); 3. Salicetum albae; 4. Salicetum apenninae; 5. Badland complexes; 6 . Uncultivated herbaceous edges; 7 . Obdelana polja, ki jih postopoma zarašča vegetacija (Linario spuriae-Stachyetum annuae). 
carpinifoliae); and an edaphoxerophilous series, where the vegetation potential is represented by a forest of Quercus pubescens (Roso sempervirentisQuercetum pubescentis). Both of these vegetation series of the grasslands are included in the association Centaureo bracteatae-Brometum erecti, which is richer in species of a Mediterranean distribution in the edaphoxerophilous series (variant of Asperula purpurea).

\subsubsection{Landscape unit of the clay substrata}

This is the most extensive landscape unit within the territory of the Reserve. Most of the surface is destined for agricultural activities, while the nuclei of woods are always few in number and small in size. These small forest patches have survived the intense anthropogenic exploitation, and they are, however, important in the reconstruction of the original potentiality of the territory. Two series of vegetation have also been identified in this landscape system. The climatophilous series is the more extensive, with the potential vegetation represented by a forest of downy oak (Quercus pubescens aggr.), as a testimony to the few remaining strips of forest. The undergrowth of this wood is a shrub layer with a dominance of broom (Spartium junceum); the invading vegetation of the cultivated fields is included in the association Linario spuriae-Stachyetum annuae. Under the fall line conditions, where the morphology of the soil leads to an accumulation of water as a result of the surface run-off, the edaphohygrophilous series of clay is established. The most mature stage of this is represented by the wood of Ulmus minor (Symphyto bulbosi-Ulmetum minoris). In areas characterized by the outcrop of the clay substrata, the climatic conditions have led to the formation of the badland systems over vast areas.

\subsection{EfFEGTS OF GRAZING}

The Table A shows the indices calculated from the phytosociological relevés carried out for the grasslands of Bromus erectus of the association Centaureo bracteatae-Brometum erecti (Habitat $6210^{*}$ ), with those subjected to grazing compared with the area left to its natural evolution. The area is located close to Monte Croce, in the southern part of the Reserve, and it belongs to the climatophilous series of the sandstone.
Table 18: Floristic-vegetational indices: maturity index (MI), index of floristic biodiversity (IFB), indices of the life-forms (IT, therophytes; IH, hemicryptophytes; IF, perennial non-hemicryprophytes). Application areas: grazing area (A Pasc), edaphoxerophilous series of compact sandstone substrata (Ex Are).

Tabela 18: Floristično-vegetacijski indeksi: indeks razvitosti (MI), indeks floristične biodiverzitete (IFB), indeks življenskih oblik (IT, terofiti; IH, hemikriptofiti; IF, večletni ne hemikriptofiti). Uporaba: paša (A Pasc), edafokserofilne serije na kompaktnem peščenjaku (Ex Are).

\begin{tabular}{lcc} 
& Grazed Area & Not Grazed Area \\
\hline IM & 4,49 & 4,65 \\
IFB & 1,06 & 0,64 \\
IH & $84,69 \%$ & $80,55 \%$ \\
\hline
\end{tabular}

The analyses of the ecological indices indicate appreciable differences in the limitation of the evolutionary dynamics of the vegetation of the pastured area with respect to the area not subjected to grazing. The maturity index of the grazed area $(\mathrm{MI}=4.49)$ is less than that of the area where the shrubs have been left to proliferate, consequently giving a greater degree of evolution to the non-grazed grasslands. The value of the floristic diversity is significantly higher in the grazed area (IFB $=1.06$ ) with respect to that calculated for the non-grazed area, where the proliferation of shrubs implies a reduction of biodiversity. The greater proportion of hemicryptophytes in the experimental area ( $\mathrm{IH}=84.69 \%)$ indicates the positive effects of the grazing on the stability of these grasslands.

\subsection{Critical observations AND AN UPDATE OF THE HABITATS OF THE ONFERNO NATURE RESERVE}

The floristic-vegetational investigation carried out as part of this study has allowed the verification of the presence of habitats of Community interest (Biondi et al. 2009) mentioned in the listing of Nature 2000 that was updated in September 2010 for the Onferno Reserve SCI and to define some considerations about their current state of conservation. In some cases, the habitats mentioned in the listing were not found during our investigation in the Onferno Nature Reserve SCI (IT4090001). 


\subsubsection{Habitats confirmed}

Habitat 9180*: Tilio-Acerion forests of the slopes, screes and ravines

This refers to the priority habitat described by the subassociation staphyletosum pinnati of the association Aceretosum obtusati-pseudoplatani. This is limited to the damp gypsum substrata along the deep incisions that overlook the lower entrance of the cave.

The presence of this habitat is confirmed, although it is currently relegated to the lower part of the gypsum ravine, where the optimum ecological conditions are conserved for the development of the typical flora of this vegetation typology and where there are fewer disturbing factors. The surface actually occupied by the forest of Tilio-Acerion, therefore, is well below its potential surface.

Habitat $6110^{*}$ : Rupicolous calcareous or basophilic grasslands of Alysso-Sedion albi

Although very localized, the presence of this priority habitat on the warm sides of the gypsum outcrops of Onferno Castle is confirmed, where the vegetation of Sedum album (Alysso-Sedetum albi) with Melica ciliata, Campanula erinus, Parietaria communis and Mattiola incana occupies an area of few tens of square meters.

Habitat 6210*: Semi-natural dry grasslands and scrubland facies on calcareous substrates (Festuco-Brometalia) (*important orchid sites)

This priority habitat is present predominantly on arenaceous substrata of the south-western areas of the territory, and it has also been identified on small surfaces adjacent to the linden wood.

Given the state of non-use of these areas, it is deemed necessary to promote active conservation activities, such as grazing or mowing, with the aim of limiting the growth of shrubs and the consequent loss of biodiversity. In particular, the management and conservation of the two small areas is strategic, as their proximity to the cave means that they are the prime foraging area for the bats, the maintenance and preservation of which are the main objectives of the Reserve.

Habitat 6220*: Pseudo-steppe with grasses and annuals of Thero-Brachypodietea

This habitat refers to the small areas of grassland with annual species that are found in the eroded parts of the badlands, in mosaic with other types of herbaceous vegetation.
Habitat 8210: Calcareous rocky slopes with chasmophytic vegetation

This habitat is represented by the shadowy cliffs of the northern aspects of the gypsum outcrop of Onferno Castle, where there has developed a vegetation characterized by the ferns Polypodium cambricum, Asplenium trichomanes, Ceterach officinarum and Phyllitis scolopendrium that can be included in the alliance Cystopteridion.

Habitat 8310: Caves not open to the public.

Both the caves not open to the public and the main cave of Onferno have been included in this habitat, which are home to numerous colonies of bats, to the cave salamander, and to invertebrates that are specialized for living in underground environments.

Habitat 92A0: Salix alba and Populus alba forest galleries

Habitat $92 \mathrm{~A} 0$ refers to the azonal vegetation that is dominated by Salix alba and can be found at the base of the badlands and along the more humid fall lines. On the basis of the analyses of the plant landscapes carried out and from the reading of the manual for the interpretation of the habitats, the presence of this formation in the Reserve can be confirmed.

Habitat 91AA*: Eastern white oak woods.

This habitat is represented by forest nuclei dominated by downy oak (Roso sempervirentisQuercetum pubescentis) found both on the sandstone and the gypsum substrata, where it is seen as the variant with Ruscus aculeatus.

\subsubsection{Habitats not corfirmed}

Habitat 5130: Juniperus communis formations on heaths or calcareous grasslands.

On the basis of the studies conducted in the territory of the Reserve, it is believed that this listed habitat is not present in this territory. Indeed, funiperus communis is present in the territory of the Reserve, but it occurs sporadically without ever forming real shrubs formations within the pastures.

Habitat 91E0*: Residual alluvial forests with $\mathrm{Al}$ nus glutinosa and Fraxinus excelsior (Alno-Padion, Alnion incanae, Salicion albae)

This priority habitat is proposed in the listing of the Onferno SCI, on the basis of this analysis 
of the landscape it is not confirmed within the Onferno Nature Reserve, because the ecological areas of this formation are covered by populations with a dominance of Salix alba and Populus alba.

In contrast, beneath the built-up areas of Onferno along the Burano River, and outside of the current perimeters of the Reserve, there is a riparian formation that could be part of Habitat 91E0. This might suggest an expansion of the protected area of this Reserve.

\section{CONCLUSIONS}

The Onferno Nature Reserve is characterized by a gypsum outcrop with inside an important colony of bats. In this area, there are also natural and semi-natural habitats that are very interesting in terms of their vegetation and flora (Priority Habitats: $9180^{*}, 6220^{*}, 6210^{*}$ and $6110^{*}$ ). In this paper, the main vegetation typologies of the area are presented, along with the description of the plant landscape through the identification of the different vegetation series distributed on the main substrata: gypsum, clayey and arenaceous. To protect the colony of bats, a Life Project has been activated, with the aim of conserving the floristic and vegetational biodiversity of the secondary grasslands in the territory, which represent the main foraging site for the bats. The study of the plant communities that were carried out before, during and after the implementation of interventions under the Project, has allowed an evaluation, although preliminary, of the results obtained and has allowed some important considerations of the economic sustainability of the management of this activity.

Despite the evident positive effects of grazing on the stability of the coenosis and on the conservation of the biodiversity, the action of the animals by itself has not proved sufficient to inhibit the growth of shrubs. It was necessary to combine the action of the animals also with the mechanical removal of the woody plants already present in the pastures.

Moreover, the morphology of the territory has led to uneven use of the pasture by the animals, that have used only a minimal part of the available area which is over-grazed (absence of regrowth, pathways and proliferation of weeds).

In the light of these observations, a series of actions were indicated to the management body of the Reserve, for provide a remedy for the proliferation of the shrubs, the over-grazing of a portion of the pastures, and the non-use of the remainder.

Furthermore, on the basis of the vegetation study it has been possible to confirm the current presence of some of the habitats of Community Interest included in the listing of the Onferno Nature Reserve SCI, and to exclude habitats 5130 and $91 \mathrm{EO}^{*}$, which were not identified in this area.

\section{REFERENCES}

Alessandrini A. \& Bonafede F. 1996: Atlante della Flora Protetta della regione Emilia Romagna. Regione Emilia Romagna, Assessorato Programmazione Ambiente, Bologna, 365pp.

Allegrezza M. 2003: Vegetazione e paesaggio vegetale della dorsale del Monte San Vicino (Appennino centrale). Fitosociologia 40 (1) suppl. 1: 3-118.

Allegrezza M., Baldoni M., Biondi E., Taffetani F. \& Zuccarello V. 2002: Studio fitosociologico dei boschi a Quercus pubescens s.l. delle Marche e delle zone contigue dell'Appennino centrosettentrionale (Italia centrale). Fitosociologia 39 (1): 161-171.

Angiolini C., Foggi B., Viciani D. \& Gabellini A. 2005: Contributo alla conoscenza sintassonomica dei boschi del Tilio acerion Klika 1955 dell'Appennino centro-settentrionale (Italia centrale). Fitosociologia 42 (1): 109-119.

Bagella S. 2001: Valore pastorale delle associazioni vegetali: un esempio di applicazione nell'Appennino Umbro-Marchigiano (Italia). Fitosociologia 38(1): 153-165.

Bertolani M. \& Rossi A. 1997: I principali caratteri geo-petrografici e geo-morfologici dell'area di Onferno (FO). In: Scaravelli D. (ed.), 1997. Onferno. Riserva Naturale Orientata. Regione Emilia Romagna, Giunti Editori.

Biondi E. 1994: The phytosociological approach to landscape study. Annali di Botanica 52: 135-141.

Biondi E. 1996: L'analisi fitosociologica nello studio integrato del paesaggio. In: "Avances en Fitosociologia" 13-22. Servicio Edit. Universidade del Pais Vasco, Bilbao.

Biondi E., Allegrezza M., Casavecchia S., Pesaresi S. \& Vagge I. 2006: Lineamenti vegetazionali e paesaggio vegetale dell'Appennino centra- 
le e settentrionale. Biogeographia vol. XXVII: 35-129.

Biondi E., Ballelli S., Allegrezza M., Guitian J. \& Taffetani F. 1986: Centaureo bracteatae-Brometum erecti ass. nova dei settori marnoso arenacei dell'Appennino centrale. Doc. phytosoc. N.S. vol. X (II): 117-126.

Biondi E., Ballelli S., Allegrezza M., Guitian J. \& Taffetani F. 1988: La vegetazione dei calanchi di Sasso Simone e Simoncello (Appennino toscomarchigiano). Braun-Blanquetia, 2: 105-115.

Biondi E., Ballelli S., Allegrezza M. \& Zuccarello V. 1995: La vegetazione dell'ordine Brometalia erecti Br.-Bl. 1936 nell'Appennino (Italia). Fitosociologia 30: 3-45.

Biondi E., Blasi C., Burrascano S., Casavecchia S., Copiz R., Del Vico E., Galdenzi D., Gigante D., Lasen C., Spampinato G., Venanzoni R. \& Zivkovic L. 2009: Manuale italiano d'interpretazione degli Habitat della Direttiva 92/43/ GEE.

Biondi E., Carni A., Vagge I., Taffetani F., Ballelli S. 2001: The vegetation of the Trifolio mediiGeranietea sanguinei Müller 1962 class in the central part of the Apennines (Italy and San Marino). Fitosociologia 38 (1): 55-65.

Biondi E., Casavecchia S., Gigante D. 2003: Contribution to the syntaxonomic knowledge of the Quercus ilex L. woods of the Central European Mediterranean Basins. Fitosociologia, 40 (1): 129-156.

Biondi E., Casavecchia S., Pinzi M., Allegrezza M., Baldoni M. 2002: The syntaxonomy of the mesophilous woods of the Central and Northern Appennines (Italy). Fitosociologia 39 (2): 71-93

Biondi E. \& Pesaresi S. 2004: The badland vegetation of the northern-central Apennines (Italy). Fitosociologia 41 (1) suppl. 1: 155-170.

Blasi C., Di Pietro R., Filesi L. 2004: Syntaxonomical revision of Quercetalia pubescenti-petraeae in the Italian Peninsula. Fitosociologia 41 (1): 87-164.

Braun-Blanquet J. (1932) 1964: Pflanzensoziologie, 3ed., 1-865. Springer -Ver., Wien.

Catorci A., Gatti R. \& Sparvoli D. 2003: Contributo alla conoscenza dei boschi bassomontani dell'Appennino maceratese (Marche - Italia centrale). Fitosociologia 40 (2): 43-53.

Conti F., Abbate G., Alessandrini A. \& Blasi C. (Eds.) 2005: An Annoted Checklist of the Italian Vascular Flora. Ministero dell'Ambiente e della Tutela del Territorio, Dipartimento di Biolo- gia Vegetale - Università degli Studi di Roma "La Sapienza". Palombi Editori, Roma.

Corbetta F. 1994: Flora e vegetazione. In: AA.VV. La vena del Gesso. Regione Emilia-Romagna. Collana naturalistica. Bologna.

Ferrari C. 1971: La vegetazione dei calanchi nelle argille scagliose del monte Paderno. Not. Fitosoc., 6: 31-51.

Ferrari C., Speranza M. 1975: La vegetazione dei calanchi dell'Emilia Romagna (con note di sistematica per la vegetazione dei suoli alomorfi interni). Not. Fitosoc. 10: 69-86.

Géhu J.M. \& Rivas-Martínez S. 1981: Notions fondamentales de phytosociologie. Ber. Int. Simp. Int. Vereinigung Vegetationskunde: 5-33.

Gubellini L. \& Zitti S., 2010: Il genere Rosa L. nelle Marche. Ann. Bot. (Roma) Supplemento 2009, n.s.: 95-114.

Laghi P. \& Pastorelli C. 2004: Le orchidee della R.N.O. di Onferno. Memorie del Museo Riserva Naturale Orientata di Onferno n.6.

Lucchi E. \& Scaravelli D. 2005: Caratteri geomorfologici dell'area di Onferno. In: Taffetani F., Zitti S. \& Scaravelli D. 2005: Flora e vegetazione della Riserva Naturale Orientata di Onferno. Regione Emilia Romagna, Cesena: 5-7.

Ministero dell'Ambiente e della Tutela del Territorio. Direzione per la Protezione della Natura 2005: Formulario standard per zone di protezione speciale (ZPS), per zone proponibili per una identificazione come siti d'importanza comunitaria (SIC) e per zone speciali di conservazione (ZSC) - Natura 2000.

Oberdorfer E. 1994: Pflanzensoziologische Exkursions Flora. Ulmer, Germany: 1050pp.

Pignatti S., 1982. Flora d'Italia. Edagricole, Bologna.

Pirone G. 1995: Vegetazione dei calanchi di Atessa (Abruzzo) e problematiche sintassonomiche della vegetazione calanchiva appenninica in fitoclimi temperato-mediterranei di transizione. Fitosociologia 30: 221-232.

Podani J. 2001: SYN-TAX 2000. Computer Programs for Data Analysis in Ecology and Systematics. User's manual. Scientia Publishing, Budapest, Hungary.

Poldini L., Vidali M., Biondi E. \& Blasi C., 2002: La classe Rhamno-Prunetea in Italia. Fitosociologia 39 (1) suppl. 2: 145-162.

Rismondo M., Lancioni A., Taffetani F. 2011: Integrated tools and methods for the analysis of agro-ecosystem's functionality through vegetational investigations. Fitosociologia 48: 41-52. 
Rivas-Martìnez S. 2005a: Avances en Geobotánica. Publicaciones Academia Nacional de Farmacia. Madrid.

Rivas-Martìnez S. 2005b: Avances en Geobotánica. Discurso apertura curso 2005. Real Acad. Farmacia. Madrid: 142pp.

Rivas-Martìnez S. 2008: Globalbioclimatics, Internet: http://www.globalbioclimatics.org

Rivas-Martìnez S., Díaz T.E., Fernández-González F., Izco J., Loidi J., Lousã \& Penas Á. 2002a: Vascular plant communities of Spain and Portugal. Itinera Geobotanica 15(2): 433-922.

Rivas-Martìnez S., Dìaz T.E., FernándezGonzález F., Izco J., Loidi J., Lousã M. \& Penas A. 2002b: Vascular plant communities of Spain and Portugal. Addenda to the syntaxonomical checklist of 2001. Itinera Geobotanica 15 (1): 5-432.

Rivas-Martìnez S., Penas A. \& Díaz T.E. 2004: Biogeographic map of Europe. Cartographic Service, University of Léon.

Ruggieri G. 1958: Gli esotici neogenici della colata gravitazionale della Val Marecchia (Appennino Romagnolo). Atti Ac. Sc.. Lett. e Arti Palermo, 17, serv.4 (1956-57): 1-170.

Taffetani F. 2000: Serie di vegetazione del complesso geomorfologico del Monte dell'Ascensione (Italia centrale). Fitosociologia 37 (1): 93-151.

Taffetani F., Orlandini S. \& Zitti S. 2009. Paesaggio vegetale di un'area pre-appenninica dell' Italia centrale: il Bosco dei Monaci Bianchi nelle Marche (Italia). Fitosociologia 46 (1): 27-47.

Taffetani F. \& Rismondo M. 2009: Bioindicators system for the evaluation of the environmental quality of agro-ecosystems. Fitosociologia 46 (2): 3-22.

Taffetani F., Zitti S., Giannangeli A. 2004: Vegetazione e paesaggio vegetale della Dorsale di Cingoli (Appennino Centrale, Dorsale Marchigiana). Fitosociologia 41 (2) suppl. 1: 83-161.

Taffetani F., Zitti S., Scaravelli D. 2005: Flora e vegetazione della Riserva Naturale Orientata di Onferno. Regione Emilia Romagna, Cesena: $157 \mathrm{pp}$.

Tutin T.G., Burges N.A., Chater A.O., Edmondson J.R., Heywood V.H., Moore D.M., Valentine D.H., Walters S.M., Webb D.A. 1993: Flora Europaea, I $2^{\text {nd }}$ ed. Cambridge University Press.

Tutin T.G., Heywood V.H., Burges N.A., Moore D.M., Valentine D.H., Walters S.M., Webb
D.A. 1964-1980: Flora Europaea, I-V. Cambridge University Press.

Tüxen R. 1956: Die heutige potentielle natürliche Vegetation als Genenstand der Vegetationskartierung. Angew. Pflanzensoz. Stolzenau, 13: 5-42.

Tüxen R. 1977: Zur Homogenität von Sigmassoziationen, ihner syntaxonomischen Ordnung und ihrer Verwendung in der Vegetationskartierung. Doc. Phytosoc., N.S. 1: 321-328.

Tüxen R. 1979: Sigmeten und Geosigmeten, ihre Ordnung und ihre Bedeutug für Wissenschaft, Naturschutz und Planung. Biogeographie, 16: 79-92.

Van der Maarel E. 1979: Trasformation of coverabundance values in phytosociology and its effects on community similarity. Vegetatio 39 : 97-144.

Zangheri P. 1936: Flora e vegetazione della fascia gessoso-calcarea del basso Appennino romagnolo. Romagna fitogeografica, vol. 4.

Received 19. 4. 2012

Revision received 14. 11. 2012

Accepted 17. 11. 2012 


\section{APPENDIX I}

\section{SPORADIC SPECIES}

\section{Table 1}

Rel. 1: Geum urbanum L. (+); Rel. 3: Helleborus bocconei Ten. (+), Anthriscus sylvestris (L.) Hoffm. ssp. sylvestris (+); Rel. 6: Alliaria petiolata (Bieb.) Cavara et Grande (+), Cornus sanguinea L. ssp. sanguinea (+); Rel. 7: Agrimonia eupatoria L. (1.1), Arabis turrita L. (+.2), Quercus ilex L. (+), Rubus ulmifolius Schott (+.2).

\section{Table 2}

Rel. 3: Rosa corymbifera Borkh. (+), Hieracium murorum L. (+), Pteridium aquilinum (L.) Kuhn (1.1), Silene vulgaris (Moench) Garcke (+); Rel. 4: Inula salicina L. (+), Dactylis glomerata L. (+), Polygala nicaeensis Risso (+.2), Bromus erectus Hudson (+.2), Coronilla scorpioides (L.) Koch (+), Inula conyzae (Griess) Meikle (+); Rel. 5: Inula salicina L. (+), Dactylis glomerata L. (+), Polygala nicaeensis Risso $(+)$, Bromus erectus Hudson (+), Pyrus communis L. (+), Aristolochia rotunda L. (1.2), Ranunculus bulbosus L. (+),Viola odorata L. (1.2); Rel. 6: Rosa canina L. (+); Rel. 7: Geum urbanum L. (+), Polypodium cambricum L. (+.2), Alliaria petiolata (Bieb.) Cavara et Grande (+.2), Lonicera caprifolium L. (+); Rel. 9: Polypodium cambricum L. (+.2), Arum italicum Miller ssp. italicum (+); Rel. 10: Geum urbanum L. (+), Rosa corymbifera Borkh. (+), Galium mollugo L. ssp. erectum Syme (+), Helianthemum nummularium (L.) Miller (+); Rel. 11: fuglans regia L. (+), Quercus ilex L. (1.2).

\section{Table 3}

Rel. 1: Rubus ulmifolius Schott (1.2), Lathyrus sylvestris L. ssp. sylvestris (+), Populus alba L. (+), Rosa canina L. (+), Populus canescens (Aiton) Sm. (+); Rel. 2: Lathyrus sylvestris L. ssp. sylvestris (+), Aegopodium podagraria L. (+); Rel. 3: Ligustrum vulgare L. (+.2), Brachypodium rupestre (Host) R. et S. (+.2), Astragalus glycyphyllos L. (+); Rel. 4: Rubus ulmifolius Schott (+), Ligustrum vulgare L. (+), Robinia pseudoacacia L. (+); Rel. 5: Vincetoxicum hirundinaria Medik. (+), Pyrus communis L. (+); Rel. 7: Dianthus balbisii Ser. ssp. liburnicus (Bartl.) Pign. (+); Rel. 9: Geum urbanum L. (+.2); Rel. 10: Carex halleriana Asso (+.2); Rel. 11: funiperus communis L. (+).

\section{Table 4}

Rel. 1: Agrostis stolonifera L. (+.2), Anthriscus sylvestris (L.) Hoffm. ssp. sylvestris (+), Asparagus acutifolius L. (+), Bunium bulbocastanum L. (+.2), Geranium robertianum L. (+), Sorbus domestica L. (+), Vicia bithynica (L.) L. (+); Rel. 2: Populus canescens (Aiton) Sm. (1.2), Vicia villosa Roth ssp. varia (Host) Corb. (+.2); Rel. 3: Carex flacca Schreber ssp. serrulata (Biv.) Greuter (1.2), Equisetum arvense L. (+), Inula salicina L. (+); Rel. 4: Quercus pubescens Willd. ssp. pubescens (2.3).

\section{Table 5}

Rel. 2: Eupatorium cannabinum L. (+.2); Rel. 5: Ranunculus bulbosus L. (+), Tussilago farfara L. (+); Rel. 6: Galium mollugo L. ssp. erectum Syme (+.2), Gymnadenia conopsea (L.) R. Br. (+), Lathyrus sylvestris L. ssp. sylvestris (1.2), Ononis spinosa L. (+), Plantago media L. (+), Polygala nicaeensis Risso (+).

\section{Table 8}

Rel. 1: Salix apennina Skvortsov (+); Rel. 4: Stachys officinalis (L.) Trevisan (+), Dipsacus fullonum L. (+), Agropyron pungens (Pers.) R. et S. (1.1), Centaurea bracteata Scop. (1.1), Anacamptis pyramidalis (L.)L.C.Rich. (+); Rel. 5: Teucrium chamaedrys L. (+.2), Geum urbanum L. (+), Arabis sagittata (Bertol.) DC. (1.1), Bromus erectus Hudson (+.2); Rel. 6: Dorycnium hirsutum (L.) Ser. (+).

\section{Table 9}

Rel. 1: Hypericum perforatum L. (1.1), Centaurium erythraea Rafn (+), Sanguisorba minor Scop. (+), Equisetum telmateja Ehrh. (1.1), Melissa romana Miller (1.2), Rubus ulmifolius Schott (2.3); Rel. 2: Festuca heterophylla Lam. (+.2), Rosa canina L. sensu Bouleng. (+), Medicago sativa L. (+); Rel. 3: Brachypodium sylvaticum (Hudson) Beauv. (1.2), Clematis vitalba L. (+), Eranthis hyemalis (L.) Salisb. (+), Leopoldia comosa (L.) Parl. (1.1), Poa sylvicola Guss. (+.2), Orobanche hederae Duby (+), Tamus communis L. (+), Bromus ramosus Hudson (+), Arum italicum Miller (+), Ranunculus ficaria L. ssp ficaria (1.2); Rel. 4: Viola alba Besser ssp. dehnhardtii (Ten.) W. Becker (1.2), Cyclamen hederifolium Aiton (+.2), Melica uniflora Retz. (+.2), Melittis melissophyllum L. (1.2), Torilis arvensis (Hudson) Link (+.2); Rel. 5: Ballota nigra L. (2.3), Anthemis tinctoria L. (+), Verbascum blattaria L. (+). 


\section{Table 10}

Rel. 1: Tordylium apulum L. (+), Agropyron repens (L.) Beauv. (+.2); Rel. 2: Sonchus oleraceus L. (1.1), Rumex conglomeratus Murray (+), Ranunculus ficaria L. (+.2), Dactylis glomerata L. (+); Rel. 3: Sonchus oleraceus L. (+), Malva sylvestris L. (+.2), Tordylium apulum L. (+), Rumex conglomeratus Murray (+); Rel. 4: Malva sylvestris L. (+); Rel. 5: Sonchus asper (L.) Hill (+), Lamium purpureum L. $(+)$, Anagallis arvensis L. (+), Polygonum aviculare L. (1.1), Verbena officinalis L. (+), Potentilla reptans L. (1.2), Galium album Miller (1.2), Plantago media L. (1.1); Rel. 6: Buglossoides purpurocaerulea (L.) Johnston (2.2), Verbena officinalis L. (1.1), Potentilla reptans L. (1.2), Galium album Miller (2.2), Medicago sativa L., (+), Torilis arvensis (Hudson) Link (+.2), Festuca heterophylla Lam. (+.2), Rosa canina L. sensu Bouleng. (+), Ligustrum vulgare L. (+), Trifolium pratense L. (+.2), Prunella vulgaris L. (+.2), Trifolium repens L. (+.2); Rel. 7: Sonchus asper (L.) Hill (1.1), Lamium purpureum L. (2.3), Anagallis arvensis L. (+), Polygonum aviculare L. (1.1), Verbena officinalis L. (1.2), Vicia villosa Roth (+.2), Cerinthe major L. (+.2), Euphorbia helioscopia L. (+).

\section{Table 11}

Rel. 1: Bellevalia romana (L.) Sweet (+); Rel. 2: Cephalanthera longifolia (Hudson) Fritsch (+); Rel. 3: Cephalanthera longifolia (Hudson) Fritsch (+), Spartium junceum L. (1.2); Rel. 6: Ranunculus velutinus Ten. (+), Cornus sanguinea L. ssp. sanguinea $(+)$, Mentha spicata L. (+.2); Rel. 7: Lathyrus latifolius L. (+), Cynosurus echinatus L. (+); Rel. 8: Cornus sanguinea L. ssp. sanguinea (+), Lathyrus latifolius L. (1.1), Cephalanthera damasonium (Miller) Druce (+); Rel. 10: Trifolium medium L. ssp. medium (1.2), Primula vulgaris Hudson ssp. vulgaris (1.1), Robinia pseudoacacia L. (1.1); Rel. 11: Cornus sanguinea L. ssp. sanguinea (+), Spartium junceum L. (2.3); R.14: Prunus spinosa L. ssp. spinosa (+); R.15: Bellevalia romana (L.) Sweet (+), Vicia tenuifolia Roth (1.2), Geranium columbinum L. (+), Melilotus sulcata Desf. (+), Rapistrum rugosum (L.) All. (+), Tordylium apulum L. (+); Rel. 16: Bellevalia romana (L.) Sweet (+), Vicia tenuifolia Roth (1.2), Geranium columbinum $\mathrm{L}$. (+), Melilotus sulcata Desf. (+), Rapistrum rugosum (L.) All. (+), Tordylium apulum L. (+.2), Gladiolus italicus Miller (+), Sherardia arvensis L. (+), Sonchus asper (L.) Hill (+), Vicia parviflora Cav. (+); Rel. 17: Ranunculus velutinus Ten. (+), Cephalanthera damasonium (Miller) Druce (+), Mentha spicata L. (+), Rosa balsamica Besser (+), Rosa canina L. (+); Rel. 18: Ranunculus velutinus Ten. (+), Trifolium medium
L. ssp. medium (+.2), Lonicera etrusca Santi (+); Rel. 19: Trifolium medium L. ssp. medium (+.2), Lonicera etrusca Santi (+.2).

\section{Table 12}

Rel. 1: Chaerophyllum temulum L. (+), Rubus ulmifolius Schott (+), Tordylium apulum L. (1.1); Rel. 2: Sherardia arvensis L. (+.2), Vicia bithynica (L.) L. (+), Adonis annua L. (+), Anagallis arvensis L. (+.2); Rel. 3: Gladiolus italicus Miller (+.2), Typhoides arundinacea (L.) Moench (+.2), Bromus hordeaceus L. (+.2), Sonchus oleraceus L. (+), Clematis vitalba L. (1.1), Cruciata laevipes Opiz (1.2), Aristolochia rotunda L. (+); Rel. 4: Galega officinalis L. (+), Gladiolus italicus Miller (+), Chaerophyllum temulum L. (+), Typhoides arundinacea (L.) Moench (+), Bromus hordeaceus L. (1.1), Sherardia arvensis L. (+), Sonchus oleraceus L. (+); Rel. 6: Clinopodium vulgare L. (+); Rel. 8: Rubus ulmifolius Schott (1.2), Vicia tenuifolia Roth (1.1); Rel. 9: Galega officinalis L. (+); Rel. 12: Avena fatua L. (1.1); Rel. 13: Melilotus elegans Salzm. (1.2); R.15: Hainardia cylindrica (Willd.) Greuter (1.1).

\section{Table 13}

Rel. 1: Rapistrum rugosum (L.) All. 1.1, Bromus tectorum L. ssp. tectorum +, Catapodium rigidum (L.) Hubbard +, Brachypodium rupestre (Host) R. et S. +; Rel. 2: Centaurium pulchellum (Swartz) Druce ssp. pulchellum +.2; Rel. 3: Tragopogon porrifolius L. +.2; Rel. 4: Lolium multiflorum Lam. +; Rel. 5: Odontites lutea (L.) Clairv. +.

\section{Table 14}

Rel. 1: Dorycnium hirsutum (L.) Ser. (+.2), Sanguisorba minor Scop. (+); Rel. 4: Ranunculus repens L. (+.2), Poa pratensis L. (+), Lathyrus aphaca L. ssp. aphaca (+); Rel. 5: Dorycnium herbaceum Vill. (1.2), Brachypodium rupestre (Host) R. et S. (+.2), Agrimonia eupatoria L. (+), Phleum bertolonii DC. (+), Vicia villosa Roth ssp. varia (Host) Corb. (1.1), Linum corymbulosum Rchb. (+). Rel. 6: Holcus lanatus L. (1.2), Festuca arundinacea Schreber (+.2), Galium mollugo L. ssp. erectum Syme (1.1), Carex flacca Schreber ssp. serrulata (Biv.) Greuter (+.2), Genista tinctoria L. (+), Galega officinalis L. (+), Salix apennina Skvortsov (1.2), funcus inflexus L. (+.2), Lathyrus sylvestris L. ssp. sylvestris (+), Populus nigra L. (+).

\section{Table 16}

Rel. 1: Centaurium pulchellum (Swartz) Druce (+); Rel. 3: Dipsacus fullonum L. (+), Vicia tenuissima 
(Bieb.) Sch. et Th. (+); Rel. 4: Agropyron repens (L.) Beauv. (+.2), Geranium columbinum L. (+), Ballota nigra L. (+.2), Trifolium campestre Schreber (+), Prunella vulgaris L. (+); Rel. 5: Carduus pycnocephalus L. (+), Cirsium vulgare (Savi) Ten. (+), Typhoides arundinacea (L.) Moench (+), Poa pratensis L. (+.2), Trifolium pratense L. (1.2), Verbena officinalis L. (+), Plantago lanceolata L. (+), Rumex crispus L. (+).

\section{Table 17}

Rel. 3: Anthemis tinctoria L. (+); Rel. 4: Tordylium apulum L. (+.2), Verbena officinalis L. (+), Galium mollugo L. ssp. erectum Syme (+.2), Potentilla reptans L. (1.2); Rel. 5: Cruciata laevipes Opiz $(+.2)$, Inula conyzae (Griess) Meikle (+), Picris hieracioides L. (+), Lathyrus pratensis L. (+).

\section{APPENDIX II}

\section{LOCALITIES OF RELEVÉS}

\section{Table 1}

Rel. 1-7: Onferno Nature Reserve: in the chalky ravine that overlooks the entrance to the karst caves, next to Castello di Onferno.

\section{Table 2}

Rel. 1-5: Onferno Nature Reserve: next to Ca Bernardo.

Rel. 6-11: Onferno Nature Reserve: next to Castello di Onferno on gypsum substrata.

\section{Table 3}

Rel. 1-12: Onferno Nature Reserve: at location Le Selve.

\section{Table 4}

Rel. 1-4: Onferno Nature Reserve: on clay substrata to the left of Castello di Onferno and at the base of the badlands next to Fornace.

\section{Table 5}

Rel. 1-6: Onferno Nature Reserve: badlands of Ripa della Morte and badlands of Fornace.

\section{Table 6}

Rel. 1-2: Onferno Nature Reserve: badlands of Ripa della Morte.

\section{Table 7}

Rel. 1: Onferno Nature Reserve: next to Castello di Onferno.

\section{Table 8}

Rel. 1-5: Onferno Nature Reserve: at location Le Selve.

Rel. 6-7: Onferno Nature Reserve: on clay substrata to the left of Castello di Onferno.

\section{Table 9}

Rel. 1-6: Onferno Nature Reserve: at the edges of the linden wood in the chalky ravine.

\section{Table 10}

Rel. 1-5: Onferno Nature Reserve: on the gypsum substrata near the visitor center of the Castello di Onferno.

\section{Table 11}

Rel. 1-20: Onferno Nature Reserve: Monte Croce.

\section{Table 12}

Rel. 1-15: Onferno Nature Reserve: badlands of Ripa della Morte.

\section{Table 13}

Rel. 1-5: Onferno Nature Reserve: badlands of Ripa della Morte.

\section{Table 14}

Rel. 1-6: Onferno Nature Reserve: at the base of the badlands next to Fornace.

\section{Table 15}

Rel. 1-3: Onferno Nature Reserve: on the sunny chalky cliffs of the Castello di Onferno

\section{Table 16}

Rel. 1-3: Onferno Nature Reserve: on clay substrata next to Arcella.

Rel. 4-5: Onferno Nature Reserve: on clay substrata next to Ca Parantonio.

\section{Table 17}

Rel. 1-3: Onferno Nature Reserve: on sandstone substrata next to Ca Bernardo.

Rel. 4-6: Onferno Nature Reserve: on sandstone substrata next to Monte Croce. 


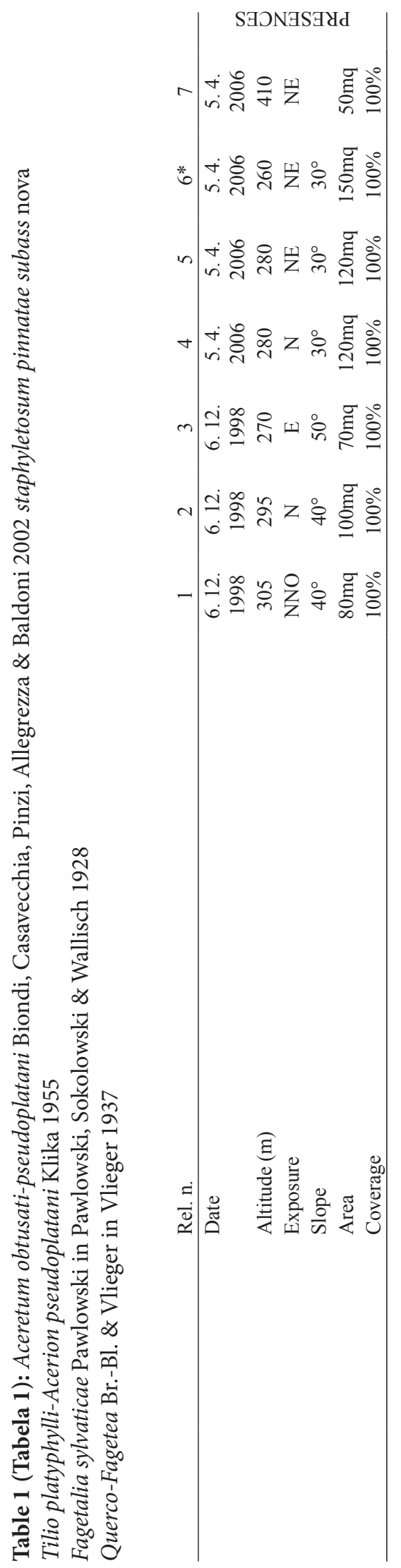

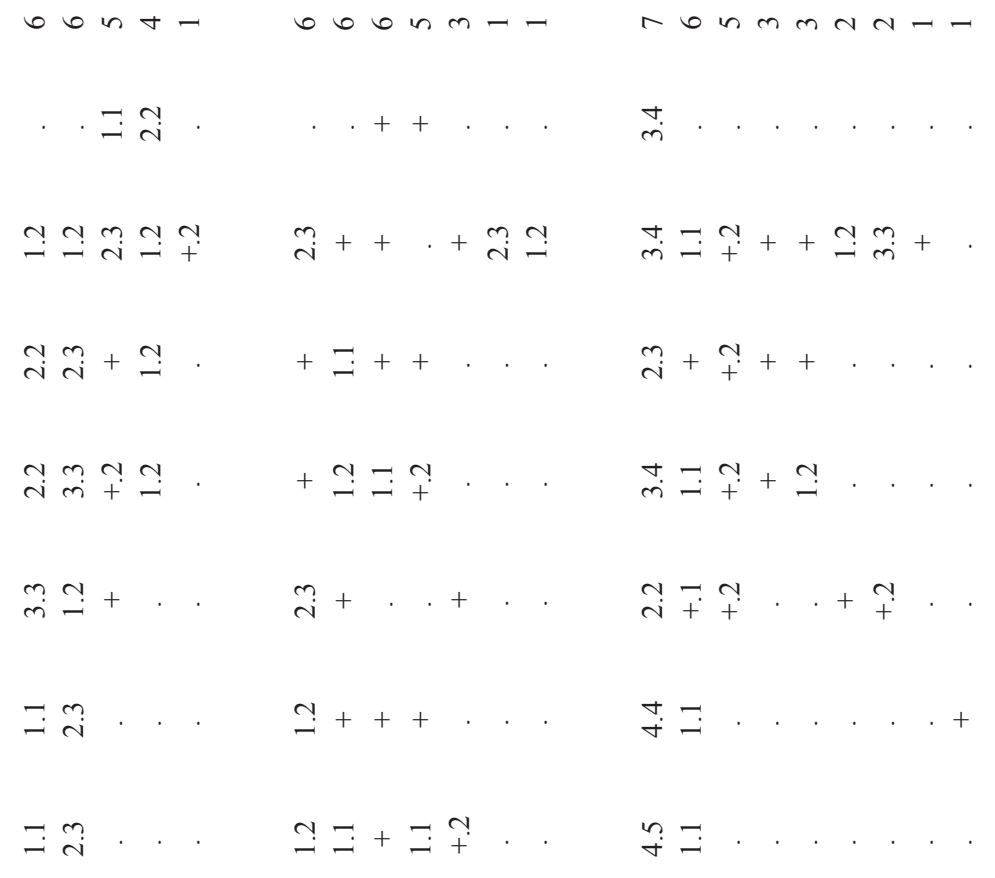
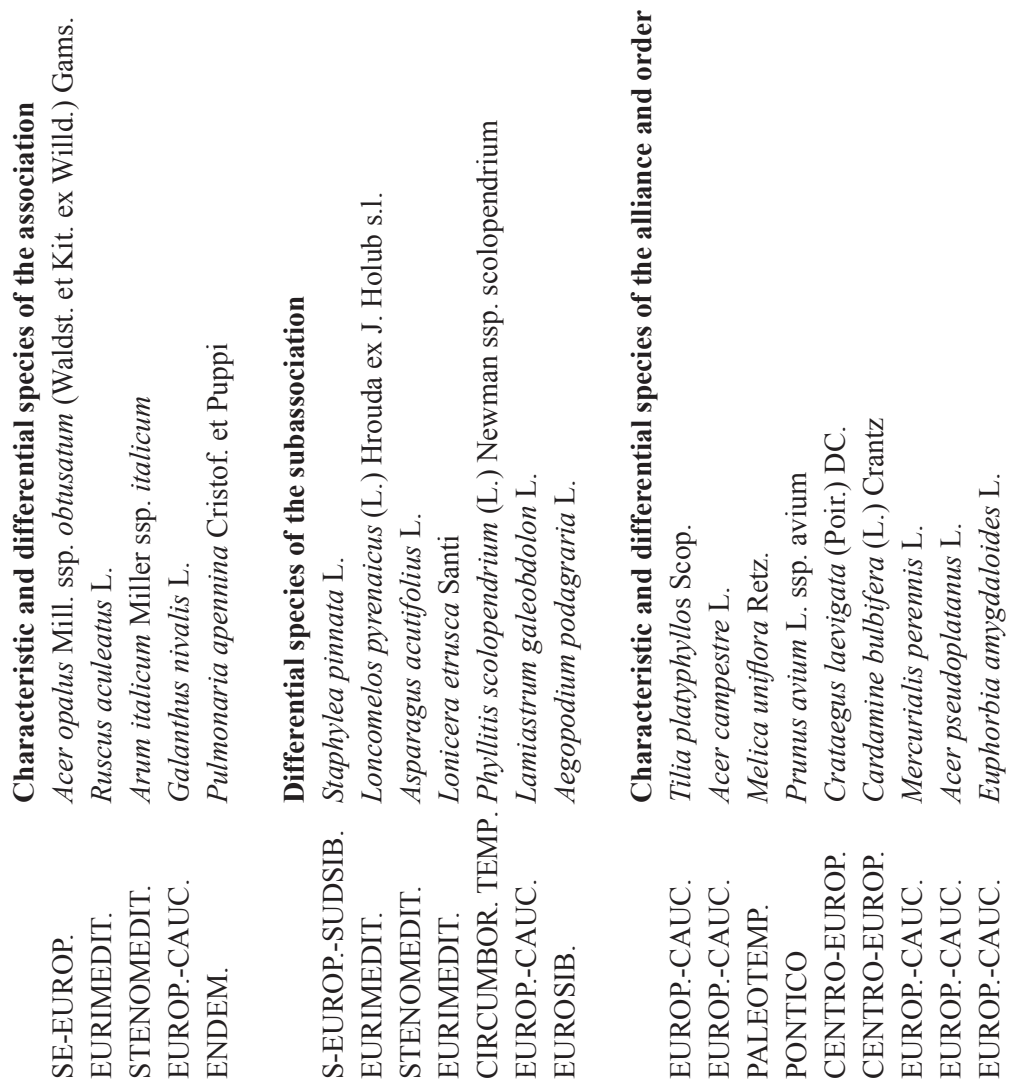

E

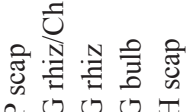
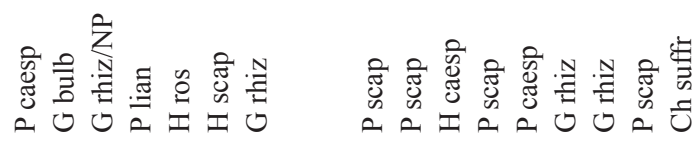


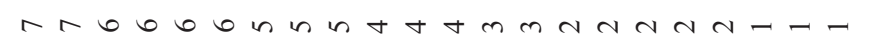

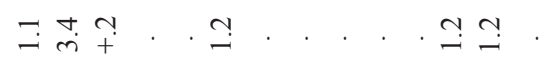

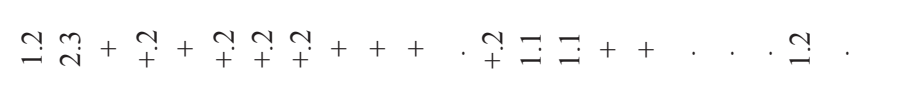

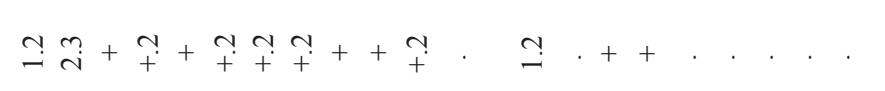

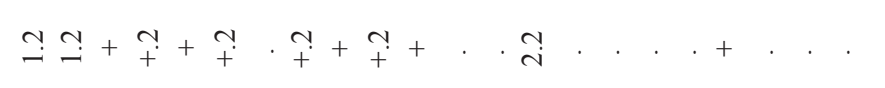

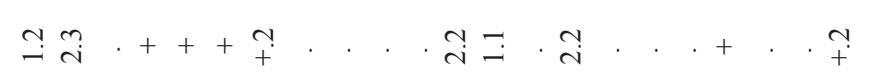

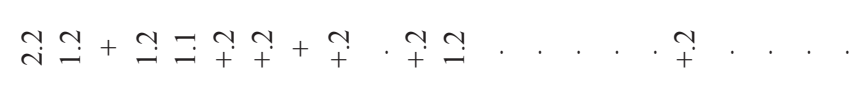

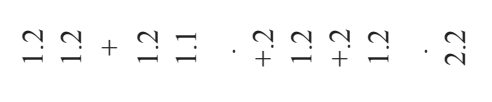

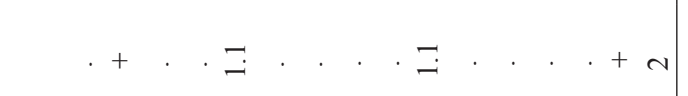
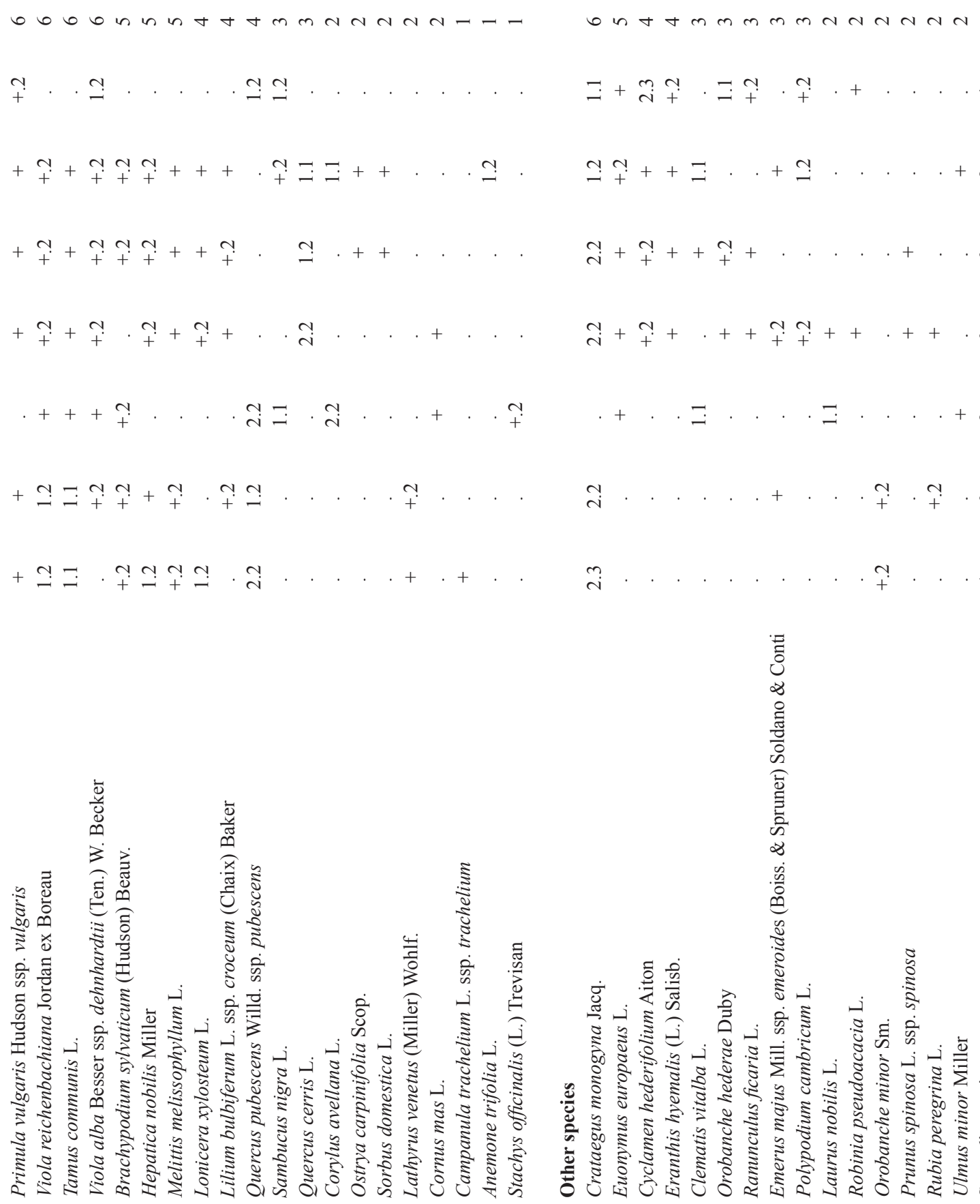

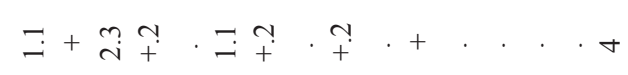

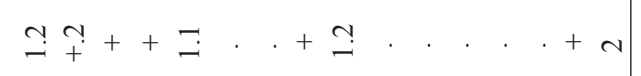

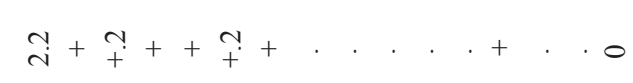

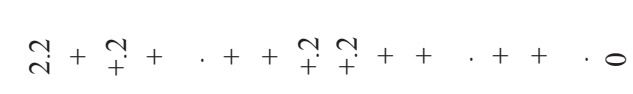

20

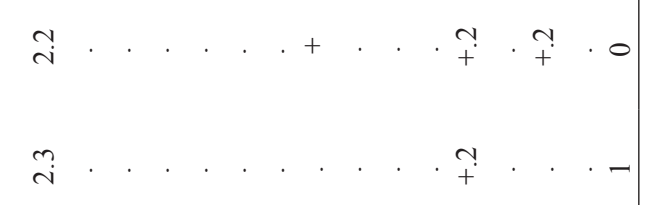

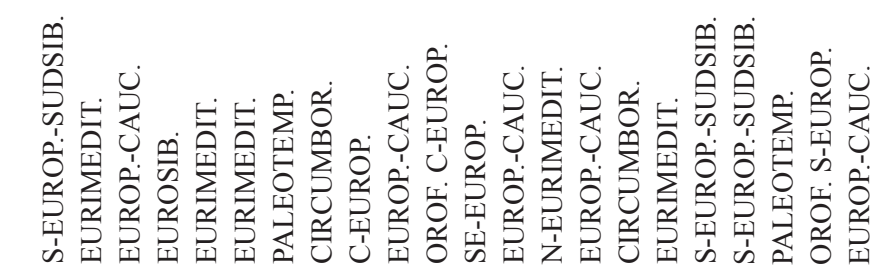

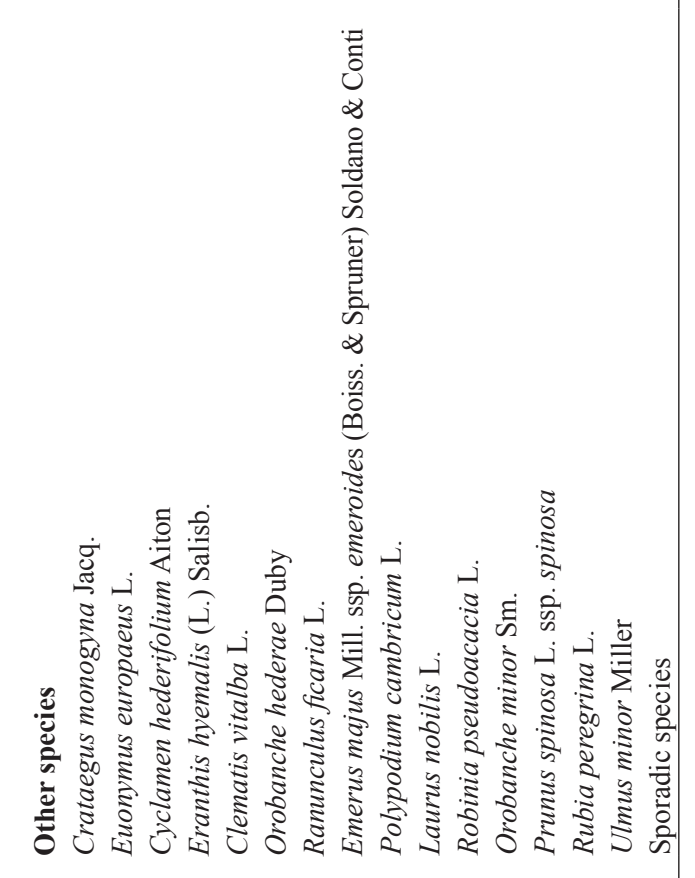

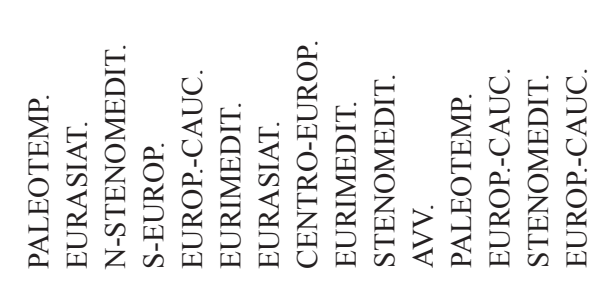

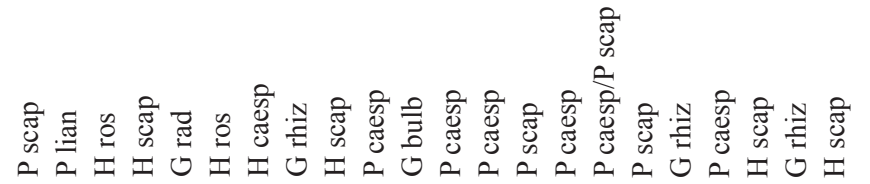

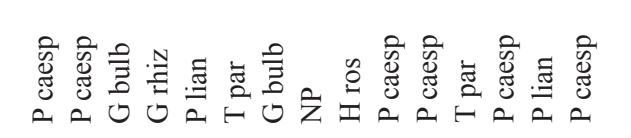




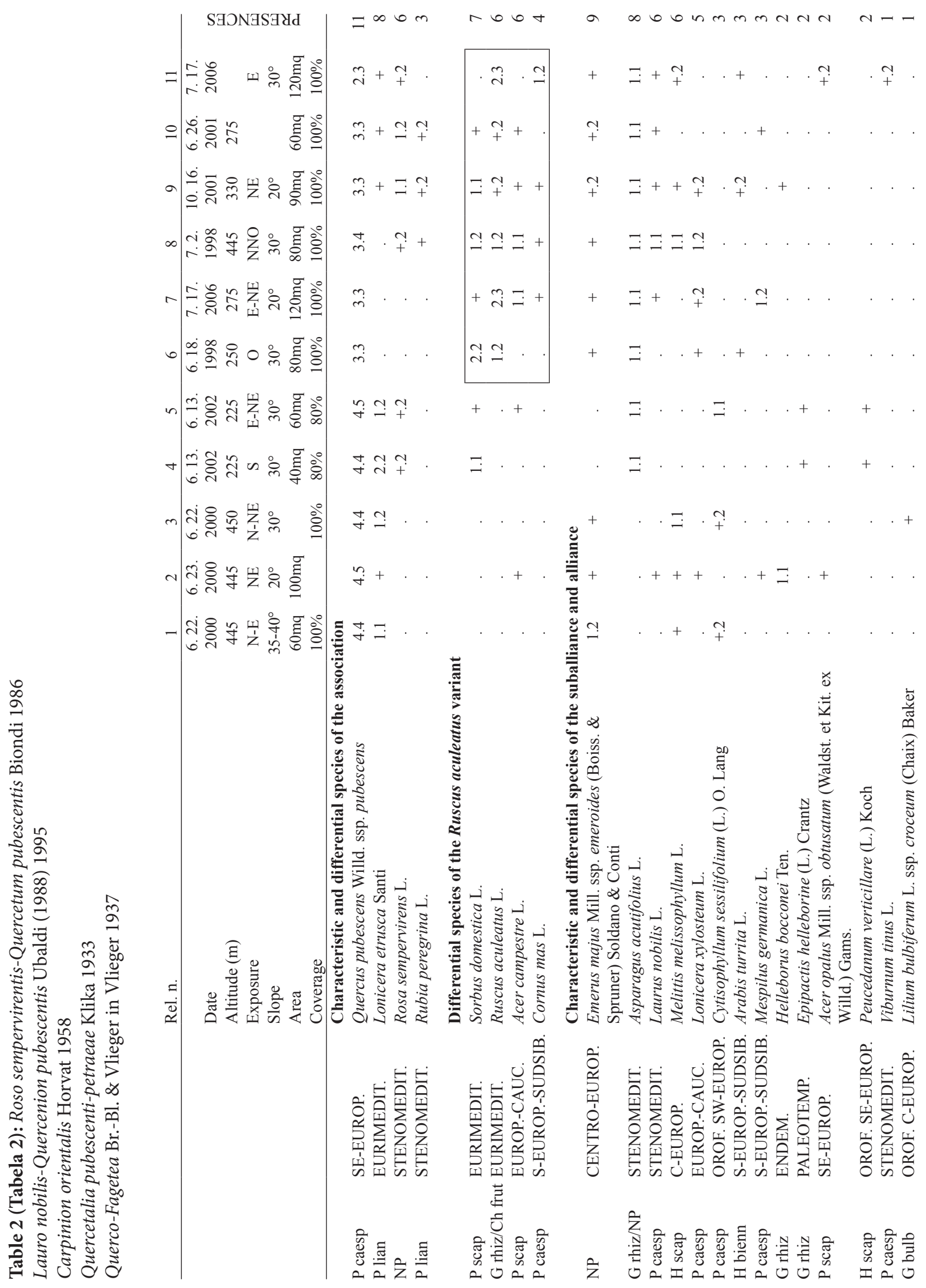




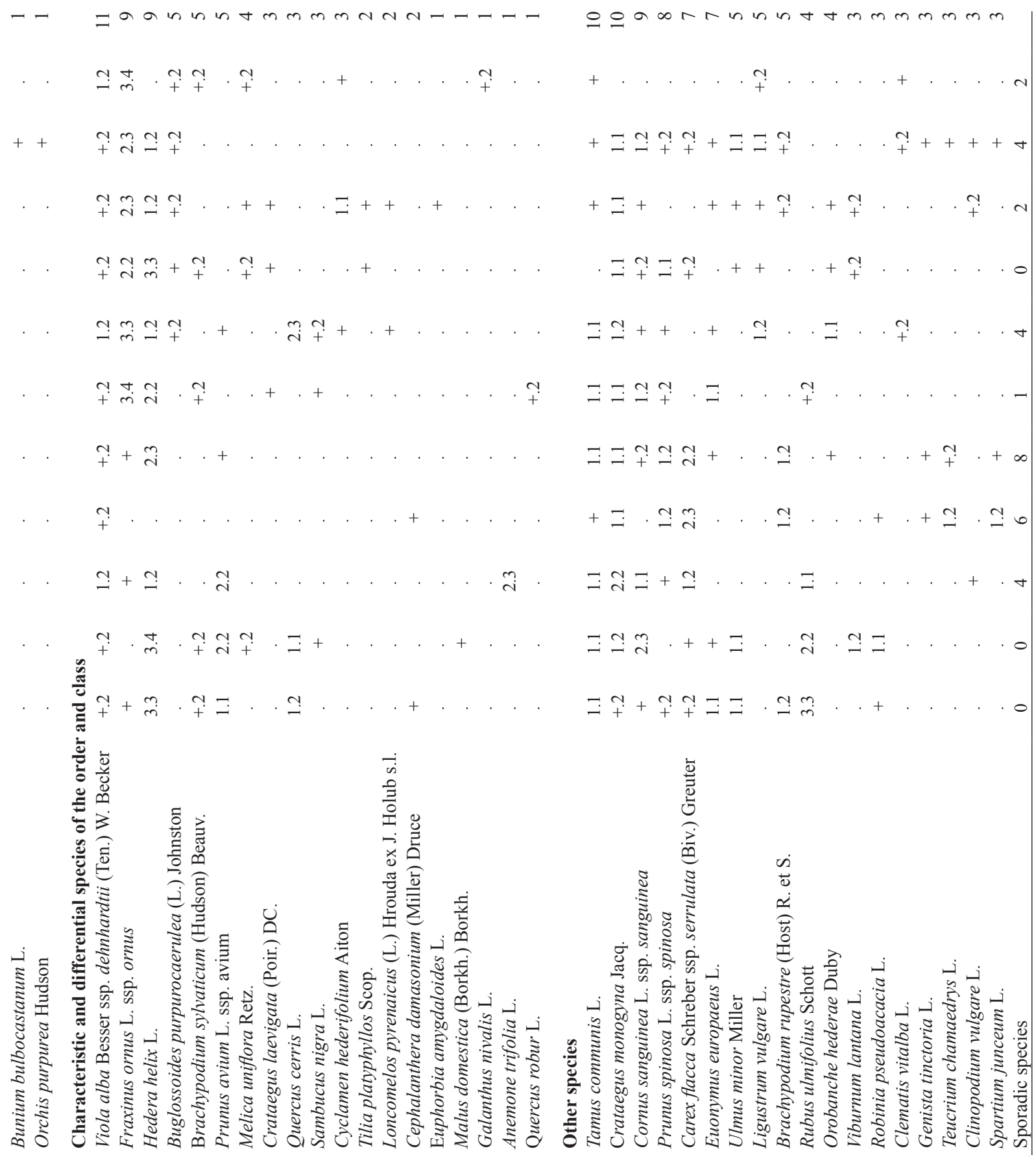
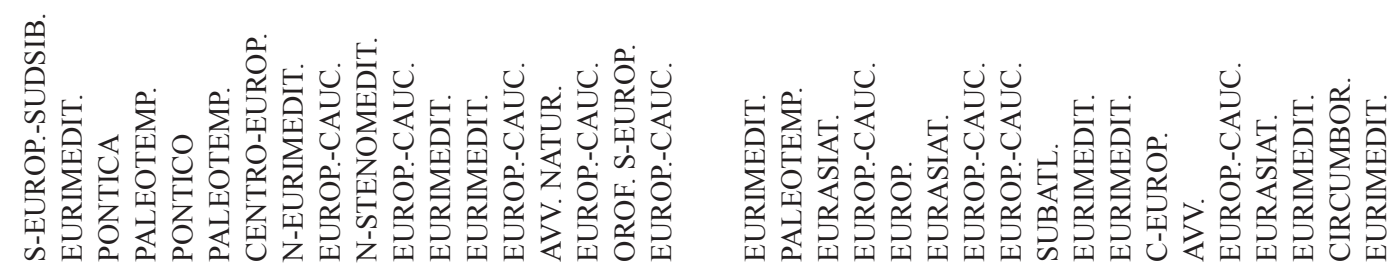

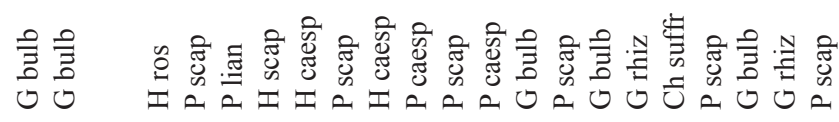

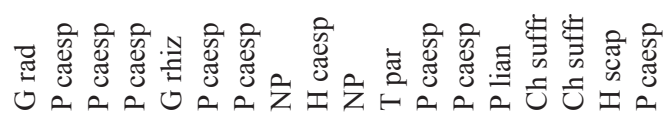




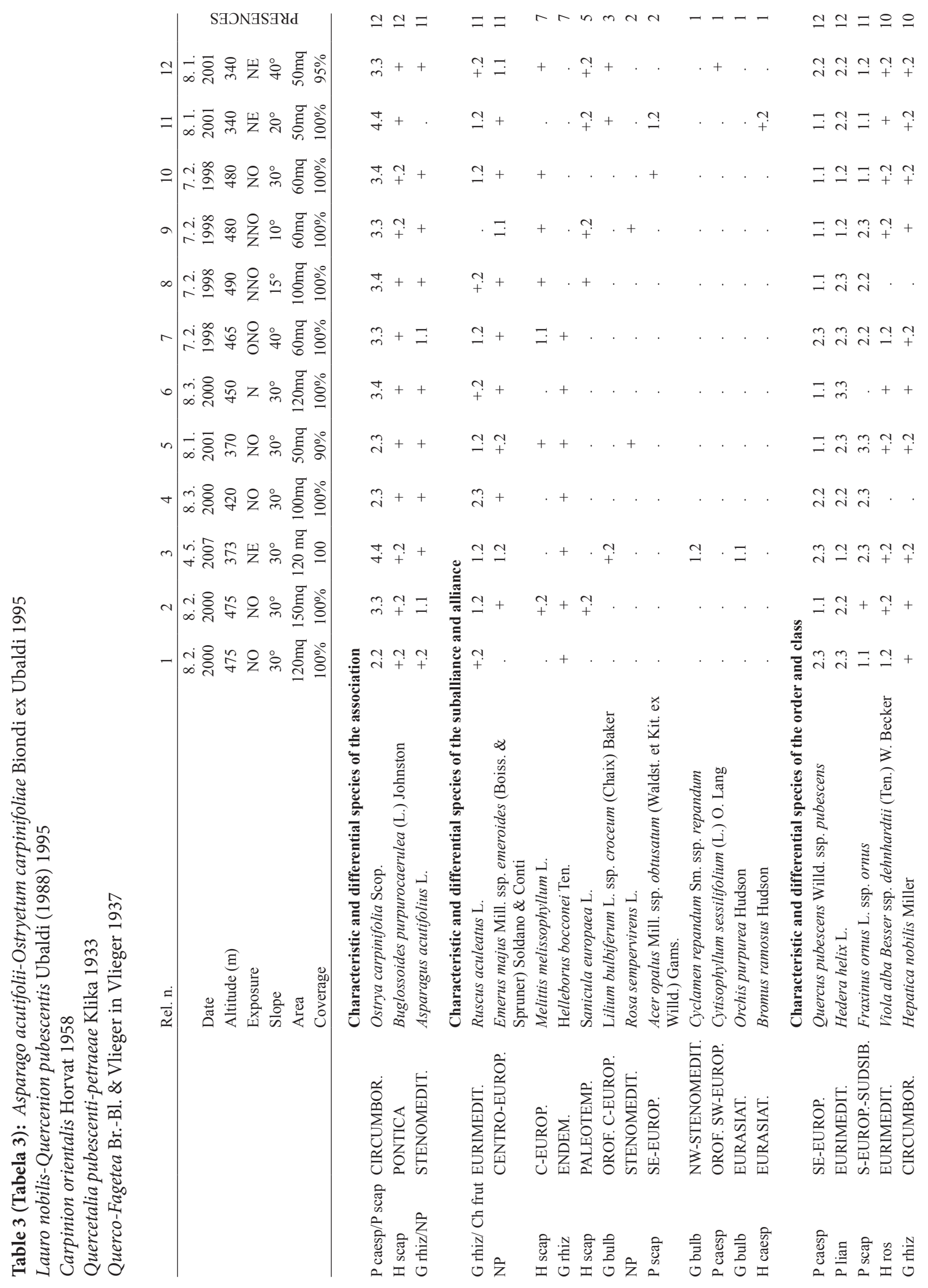




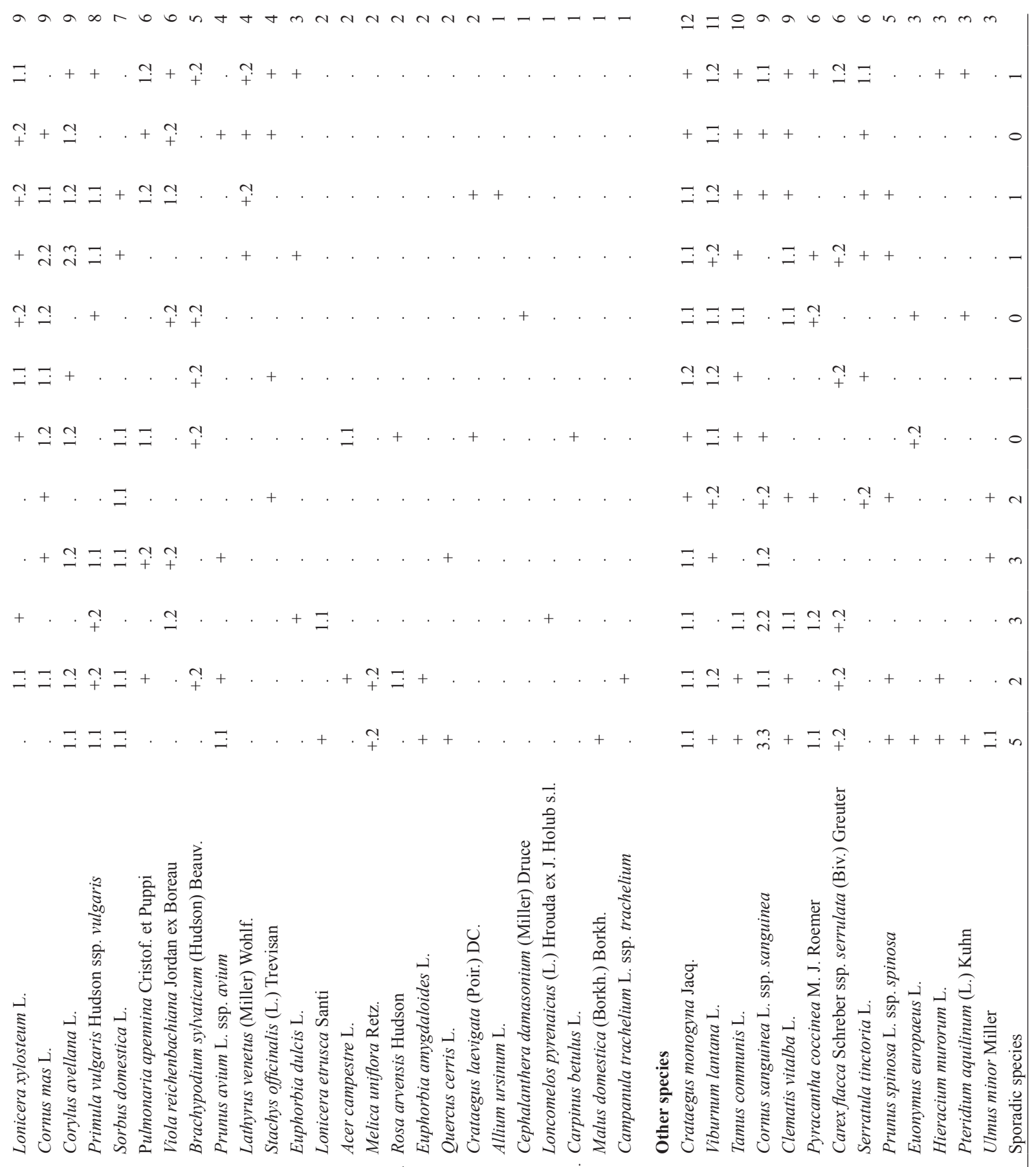

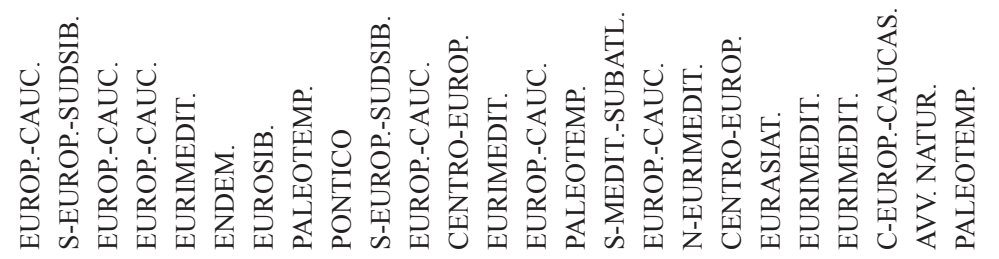

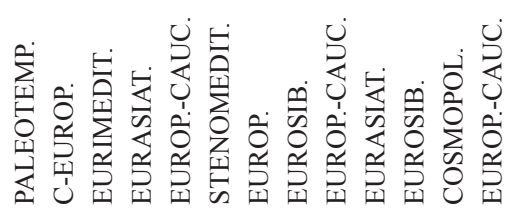

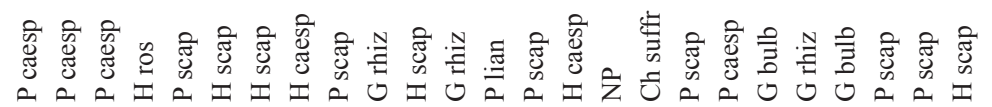

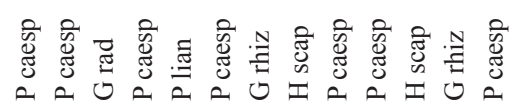


Table 4 (Tabela 4): Symphyto bulbosi-Ulmetum minoris Biondi \& Allegrezza, 1996

Alnion incanae Pawlowski in Pawlowski, Sokolowski and Wallisch 1928

Salicetalia purpureae Moor 1958

Salici purpureae-Populetea nigrae (Rivas-MartÍnez \& Cantó ex Rivas-MartÍnez, Báscones, T.E. Díaz, FernándezGonzález \& Loidi 1991) Rivas-MartÍnez, T.E. Díaz, Fernández-González, Izco, Loidi, Lousã and Penas 2001

\begin{tabular}{|c|c|c|c|c|c|c|c|}
\hline & & Rel. n. & 1 & 2 & 3 & 4 & \\
\hline & & Date & $5 / 11 / 2001$ & $5 / 11 / 2001$ & $5 / 11 / 2001$ & $5 / 11 / 2001$ & \\
\hline & & Altitude (m) & 325 & 190 & 420 & 190 & 至 \\
\hline & & Exposure & NO & & $\mathrm{S}$ & & 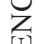 \\
\hline & & Slope & $20^{\circ}$ & & $0^{\circ}$ & & 至 \\
\hline & & Area & $50 \mathrm{mq}$ & $60 \mathrm{mq}$ & $40 \mathrm{mq}$ & $40 \mathrm{mq}$ & \\
\hline & & Coverage & $100 \%$ & $100 \%$ & $100 \%$ & $100 \%$ & \\
\hline & & \multicolumn{6}{|c|}{ Characteristic and differential species of the association } \\
\hline P caesp & EUROP.-CAUC. & Ulmus minor Miller & 5.5 & 3.4 & 4.4 & 3.3 & 4 \\
\hline \multirow[t]{2}{*}{ P caesp } & EUROP.-CAUC. & Sambucus nigra $\mathrm{L}$. & . & . & + & 1.2 & 2 \\
\hline & & \multicolumn{6}{|c|}{ Characteristic and differential species of the suballiance, alliance, order and class } \\
\hline G rhiz & STENOMEDIT. & Arum italicum Miller ssp. italicum & 1.2 & 1.1 & . & + & 3 \\
\hline H caesp & PALEOTEMP. & Brachypodium sylvaticum (Hudson) Beauv. & +.2 & . & 1.1 & . & 2 \\
\hline P scap & PALEOTEMP. & Populus nigra $\mathrm{L}$. & . & + & . & + & 2 \\
\hline P scap & PALEOTEMP. & Salix alba $\mathrm{L}$. & . & + & . & + & 2 \\
\hline NP & ENDEM. & Salix apennina Skvortsov & . & + & 2.3 & . & 2 \\
\hline \multirow[t]{2}{*}{ G bulb } & EURIMEDIT. & Aristolochia rotunda $\mathrm{L}$. & 1.1 & . & . & . & 1 \\
\hline & & \multicolumn{6}{|c|}{ Characteristic and differential species of the Rhamno-Prunetea class } \\
\hline P caesp & PALEOTEMP. & Crataegus monogyna Jacq. & 2.3 & 1.1 & + & 1.1 & 4 \\
\hline P caesp & EUROP.-CAUC. & Prunus spinosa L. ssp. spinosa & 1.1 & + & 2.3 & + & 4 \\
\hline NP & EURIMEDIT. & Rubus ulmifolius Schott & 1.2 & 1.1 & + & 1.2 & 4 \\
\hline P caesp & EURASIAT. & Cornus sanguinea L. ssp. sanguinea & + & . & +.2 & 1.1 & 3 \\
\hline P caesp & EURASIAT. & Euonymus europaeus L. & 1.2 & + & . & 1.2 & 3 \\
\hline NP & PALEOTEMP. & Rosa canina L. & + & +.2 & . & + & 3 \\
\hline P lian & EUROP.-CAUC. & Clematis vitalba $\mathrm{L}$. & + & 1.1 & . & 1.1 & 3 \\
\hline NP & EUROP.-CAUC. & Ligustrum vulgare L. & . & . & . & 1.2 & 1 \\
\hline \multirow[t]{2}{*}{ P lian } & EURIMEDIT. & Lonicera etrusca Santi & + & . & . & . & 1 \\
\hline & & Other species & & & & & \\
\hline H scap & EURASIAT. & Galium mollugo L. ssp. erectum Syme & +.2 & 1.1 & . & + & 3 \\
\hline P scap & EUROP.-CAUC. & Acer campestre L. & + & . & + & 1.2 & 3 \\
\hline G rhiz & CIRCUMBOR. & Elymus repens (L.) Gould ssp. repens & . & +.2 & . & 1.2 & 2 \\
\hline H scap & EURIMEDIT. & Ballota nigra $\mathrm{L}$. & . & +.2 & . & +.2 & 2 \\
\hline T scap & EURASIAT. & Chaerophyllum temulum $\mathrm{L}$. & . & 1.2 & . & +.2 & 2 \\
\hline $\mathrm{H}$ ros & PALEOTEMP. & Potentilla reptans $\mathrm{L}$. & . & 1.2 & . & +.2 & 2 \\
\hline P caesp & W-STENOMEDIT. & Tamarix gallica $\mathrm{L}$. & +.2 & + & . & . & 2 \\
\hline G rad & EURIMEDIT. & Tamus communis L. & + & . & 1.1 & . & 2 \\
\hline \multirow[t]{2}{*}{ P lian } & EURIMEDIT. & Hedera helix L. & 4.4 & . & 1.1 & . & 2 \\
\hline & & Sporadic species & 7 & 2 & 3 & 1 & \\
\hline
\end{tabular}


Table 5 (Tabela 5): Salicetum apenninae Pedrotti, Spada, Conti, 1996

Salicion eleagni Aichinger 1933 nom. mut. propos. Rivas-Martínez, Díaz, Fernández-González, Izco, Loidi, Lousã \& Penas 2002; Salicetalia purpureae Moor 1958

Salici purpureae-Populetea nigrae (Rivas-Martínez \& Cantó ex Rivas-Martínez, Báscones, T.E. Díaz, FernándezGonzález \& Loidi 1991) Rivas-Martínez, T.E. Díaz, Fernández-González, Izco, Loidi, Lousã \& Penas 2001

\begin{tabular}{|c|c|c|c|c|c|c|c|c|c|}
\hline & & Rel. n. & 1 & 2 & 3 & 4 & 5 & 6 & \\
\hline & & & $6 / 25 /$ & $6 / 25 /$ & $6 / 25 /$ & $6 / 23 /$ & $6 / 23 /$ & $6 / 23 /$ & \\
\hline & & Date & 2001 & 2001 & 2001 & 2000 & 2000 & 2000 & 王 \\
\hline & & Altitude (m) & 270 & 270 & 270 & 350 & 370 & 370 & 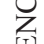 \\
\hline & & Exposure/Slope & & & & $\mathrm{N} / 10^{\circ}$ & $\mathrm{N} / 30^{\circ}$ & $\mathrm{N} / 30^{\circ}$ & $\frac{1}{2}$ \\
\hline & & Area & $40 \mathrm{mq}$ & $30 \mathrm{mq}$ & $30 \mathrm{mq}$ & $60 \mathrm{mq}$ & & & $\vec{a}$ \\
\hline & & Coverage & $100 \%$ & $100 \%$ & $100 \%$ & $100 \%$ & $100 \%$ & $100 \%$ & \\
\hline & & Characteristic species of the association & & & & & & & \\
\hline NP & ENDEM. & Salix apennina Skvortsov & 3.3 & 3.4 & 2.3 & 2.3 & 4.5 & 4.4 & 6 \\
\hline & & Differential species of the Milium effusum variant & & & & & & & \\
\hline G rhiz & CIRCUMBOR. & Milium effusum $\mathrm{L}$. & 2.3 & 1.2 & +.2 & . & . & . & 3 \\
\hline G rhiz & STENOMEDIT. & Arundo plinii Turra & 1.2 & +.2 & . & . & . & . & 2 \\
\hline G rhiz & EURASIAT. & Petasites hybridus (L.) Gaertn., Meyer et Sch. ssp. hybridus & +.2 & 1.1 & . & . & . & . & 2 \\
\hline H scap & E-EUROP.-PONTICA & Galega officinalis L. & + & +.2 & + & . & . & . & 3 \\
\hline & & Characteristic and differential species of the suballianc & ce, allia & nce, or & rder ar & nd clas & & & \\
\hline G rhiz & CIRCUMBOR. & Equisetum telmateja Ehrh. & . & + & 1.1 & 1.2 & 1.1 & 1.1 & 5 \\
\hline H rept & CIRCUMBOR. & Agrostis stolonifera L. & +.2 & +.2 & +.2 & . & . & . & 3 \\
\hline H caesp & PALEOTEMP. & Brachypodium sylvaticum (Hudson) Beauv. & . & . & . & +.2 & +.2 & +.2 & 3 \\
\hline P scap & PALEOTEMP. & Populus alba L. & . & . & + & . & . & . & 1 \\
\hline P caesp & EUROP.-CAUC. & Ulmus minor Miller & . & . & + & . & . & . & 1 \\
\hline H scap & CIRCUMBOR. & Artemisia vulgaris L. & . & + & . & . & . & . & 1 \\
\hline P scap & PALEOTEMP. & Salix alba $\mathrm{L}$. & . & + & . & . & . & . & 1 \\
\hline$P$ caesp & EUROSIB. & Salix viminalis $\mathrm{L}$. & . & . & + & . & . & . & 1 \\
\hline P lian & EUROP.-CAUC. & Clematis vitalba $\mathrm{L}$. & . & . & . & + & . & . & 1 \\
\hline & & Characteristic and differential species of the Rhamno- & Prunete & $\boldsymbol{a}$ class & & & . & . & \\
\hline NP & EURIMEDIT. & Rubus ulmifolius Schott & 1.1 & 1.1 & 1.1 & 1.1 & 1.1 & 1.1 & 6 \\
\hline$P$ caesp & EURASIAT. & Cornus sanguinea L. ssp. sanguinea & 1.1 & + & . & 3.4 & 1.2 & 2.2 & 5 \\
\hline$P$ caesp & PALEOTEMP. & Crataegus monogyna Jacq. & . & + & + & . & + & 1.1 & 4 \\
\hline NP & PALEOTEMP. & Rosa canina $\mathrm{L}$. & + & + & + & . & . & . & 3 \\
\hline$P$ caesp & EURIMEDIT. & Spartium junceum L. & + & 1.1 & . & 1.2 & . & . & 3 \\
\hline$P$ caesp & S-EUROP.-SUDSIB. & Cornus mas L. & . & . & 1.2 & . & . & . & 1 \\
\hline NP & CENTRO-EUROP. & $\begin{array}{l}\text { Emerus majus Mill. ssp. emeroides (Boiss. \& Spruner) } \\
\text { Soldano \& Conti }\end{array}$ & . & . & + & . & . & . & 1 \\
\hline & & Other species & & & & & & & \\
\hline $\mathrm{H}$ bienn & PALEOTEMP. & Daucus carota L. & + & + & + & . & . & . & 3 \\
\hline Ch suffr & EURASIAT. & Genista tinctoria L. & +.2 & + & + & . & . & . & 3 \\
\hline H scap & EUROSIB. & Leucanthemum vulgare Lam. ssp. vulgare & + & + & . & . & . & + & 3 \\
\hline H scap & OROF. SE-EUROP. & Peucedanum verticillare (L.) Koch & + & . & + & . & + & . & 3 \\
\hline NP & STENOMEDIT. & Rosa sempervirens L. & 1.1 & + & + & . & . & . & 3 \\
\hline G rhiz & EUROP. & Carex flacca Schreber ssp. serrulata (Biv.) Greuter & 1.2 & 1.2 & . & . & . & . & 2 \\
\hline H scap & CIRCUMBOR. & Clinopodium vulgare $\mathrm{L}$. & . & . & . & . & + & + & 2 \\
\hline H caesp & PALEOTEMP. & Dactylis glomerata L. & + & + & . & . & . & . & 2 \\
\hline H caesp & CIRCUMBOR. & Holcus lanatus L. & . & +.2 & . & . & + & . & 2 \\
\hline H scap & EUROP.-CAUC. & Inula salicina L. & . & +.2 & . & . & + & . & 2 \\
\hline $\mathrm{H}$ ros & PALEOTEMP. & Potentilla reptans $\mathrm{L}$. & + & + & . & . & . & . & 2 \\
\hline & & Sporadic species & 0 & 1 & 6 & 0 & 0 & 2 & \\
\hline
\end{tabular}


Table 6 (Tabela 6): Salicetum albae Issler 1926

Salicion albae Soó 1930 em Moor 1958

Salicetalia purpureae Moor 1958

Salici purpureae-Populetea nigrae (Rivas-Martínez \& Cantó ex Rivas-Martínez, Báscones, T.E. Díaz, FernándezGonzález \& Loidi 1991) Rivas-Martínez, T.E. Díaz, Fernández-González, Izco, Loidi, Lousã \& Penas 2001

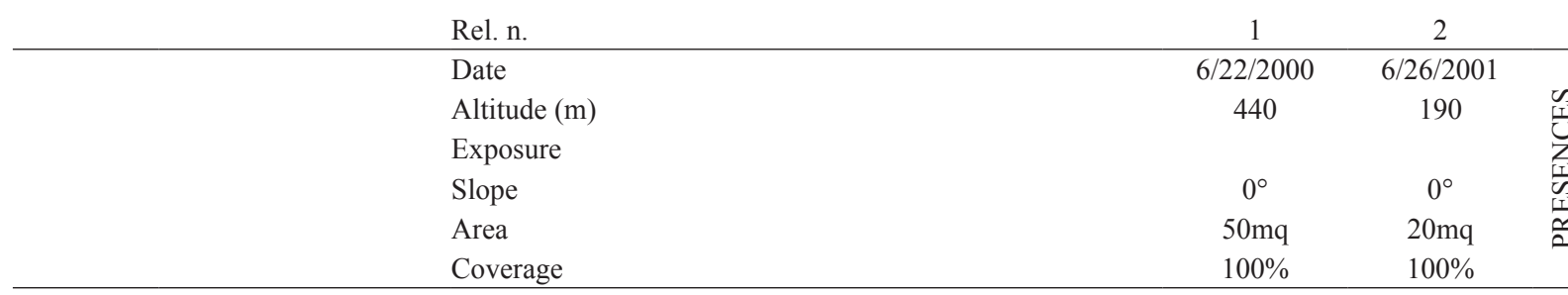

\begin{tabular}{lllrr}
\multicolumn{2}{c}{ Characteristic and differential species of the association } & 1.1 & +.2 \\
P scap & PALEOTEMP. & Populus nigra L. & 3.3 & 4.4 \\
P scap & PALEOTEMP. & Salix alba L. & 1.2 & 2 \\
NP & ENDEM. & Salix apennina Skvortsov & +.2
\end{tabular}

\begin{tabular}{|c|c|c|c|c|c|}
\hline \multirow[b]{2}{*}{ G rhiz } & \multirow[b]{2}{*}{ CIRCUMBOR. } & \multicolumn{4}{|c|}{ Characteristic and differential species of the suballiance, alliance, order and class } \\
\hline & & Equisetum telmateja Ehrh. & +.2 & +.2 & 2 \\
\hline P caesp & EUROSIB. & Salix triandra L. & . & 2.2 & 1 \\
\hline \multirow[t]{2}{*}{ H caesp } & PALEOTEMP. & Brachypodium sylvaticum (Hudson) Beauv. & +.2 & . & 1 \\
\hline & & \multicolumn{3}{|c|}{ Characteristic and differential species of the Rhamno-Prunetea class } & \\
\hline P caesp & EURASIAT. & Cornus sanguinea L. ssp. sanguinea & 2.3 & + & 2 \\
\hline NP & EURIMEDIT. & Rubus ulmifolius Schott & 1.1 & + & 2 \\
\hline P caesp & PALEOTEMP. & Crataegus monogyna Jacq. & . & + & 1 \\
\hline P caesp & EURASIAT. & Euопутия europaeus L. & 1.2 & . & 1 \\
\hline P caesp & EUROP.-CAUC. & Cornus sanguinea L. ssp. sanguinea & +.2 & . & 1 \\
\hline \multirow[t]{2}{*}{ NP } & PALEOTEMP. & Rosa canina L. sensu Bouleng. & . & + & 1 \\
\hline & & Other species & & & \\
\hline H scap & EURIMEDIT. & Pulicaria dysenterica (L.) Bernh. & + & +.2 & 2 \\
\hline G rad & EURIMEDIT. & Tamus communis $\mathrm{L}$. & 1.1 & + & 2 \\
\hline P scap & AVV. & Acer negundo L. & 1.1 & . & 1 \\
\hline G rhiz & EUROSIB. & Aegopodium podagraria $\mathrm{L}$. & + & . & 1 \\
\hline G rhiz & CIRCUMBOR. & Elymus repens (L.) Gould ssp. repens & . & 1.2 & 1 \\
\hline H scap & CIRCUMBOR. & Artemisia vulgaris L. & + & . & 1 \\
\hline H scap & EURIMEDIT. & Ballota nigra L. & . & +.2 & 1 \\
\hline P lian & EUROP.-CAUC. & Clematis vitalba $\mathrm{L}$. & . & + & 1 \\
\hline H scap & CIRCUMBOR. & Clinopodium vulgare $\mathrm{L}$. & + & . & 1 \\
\hline $\mathrm{H}$ bienn & EURIMEDIT. & Dipsacus fullonum $\mathrm{L}$. & . & + & 1 \\
\hline H scap & PALEOTEMP. & Epilobium hirsutum L. & . & 1.2 & 1 \\
\hline G rhiz & CIRCUMBOR. & Equisetum arvense $\mathrm{L}$. & . & 1.2 & 1 \\
\hline H scap & E-EUROP.-PONTICA & Galega officinalis L. & . & +.2 & 1 \\
\hline H scap & EURASIAT. & Galium mollugo L. ssp. erectum Syme & . & 1.1 & 1 \\
\hline H scap & PALEOTEMP. & Hypericum perforatum $\mathrm{L}$. & + & . & 1 \\
\hline H scap & OROF. SE-EUROP. & Peucedanum verticillare (L.) Koch & + & . & 1 \\
\hline H scap & EUROSIB. & Picris hieracioides L. & + & . & 1 \\
\hline $\mathrm{H}$ ros & PALEOTEMP. & Potentilla reptans $\mathrm{L}$. & + & . & 1 \\
\hline G rhiz & PALEOTEMP. & Tussilago farfara $\mathrm{L}$. & . & 1.1 & 1 \\
\hline
\end{tabular}


Table 7 (Tabela 7): Rubo ulmifolii-Ligustretum vulgare Poldini 1989

Fraxino orni-Berberidenion Poldini \& Vidali 1995

Berberidion vulgaris Br.-Bl. 1950

Prunetalia spinosae R. Tx. 1952

Rhamno-Prunetea Rivas Goday et Boria Carbonell ex Tüxen 1962

\begin{tabular}{lc} 
Rel. n. & 1 \\
Date & $5 / 4 / 2006$ \\
Altitude (m) & 275 \\
Exposure & S-SE \\
Slope & $20^{\circ}$ \\
Area & $20 \mathrm{mq}$ \\
Coverage & $100 \%$ \\
\hline
\end{tabular}

$\begin{array}{lll}\text { P caesp } & \text { EURASIAT. } & \text { Characteristic and differential species of the association } \\ \text { NP } & \text { EUROP.-CAUC. } & \text { Ligustrum vulgare }\end{array}$

NP EUROP.-CAUC. Ligustrum vulgare $\quad$ L $\quad 1.1$

$\begin{array}{lllr} & & \text { Characteristic and differential species of the suballiance, alliance, order and class } \\ \text { NP } & \text { EURIMEDIT. } & \text { Rubus ulmifolius } \text { Schott } & 1.2 \\ \text { P lian } & \text { EURIMEDIT. } & \text { Hedera helix } \text { L. } & 1.2 \\ \text { P caesp } & \text { EUROP.-CAUC. } & \text { Prunus spinosa } \text { L. ssp. spinosa } & 3.3 \\ \text { P caesp } & \text { PALEOTEMP. } & \text { Crataegus monogyna Jacq. } & 1.1 \\ \text { P caesp } & \text { EURASIAT. } & \text { Euonymus europaeus } \text { L. } & 1.1 \\ \text { G rhiz } & \text { STENOMEDIT. } & \text { Asparagus acutifolius } \text { L. } & +\end{array}$

H scap PALEOTEMP. Anthriscus sylvestris (L.) Hoffm. ssp. sylvestris $\quad+.2$

H scap EURIMEDIT. Ballota nigra L. $\quad+$

P scap S-EUROP.-SUDSIB. Fraxinus ornus L. ssp. ornus $\quad 1.2$

H scap CIRCUMBOR. Geum urbanum L. +.2

P caesp STENOMEDIT. Olea europaea L. +

P scap PONTICO Prunus avium L. ssp. avium +

P scap N-EURIMEDIT. Quercus cerris L. 1.2

P caesp SE-EUROP. Quercus pubescens Willd. ssp. pubescens 1.2

P caesp EUROP.-CAUC. Ulmus minor Miller $\quad+.2$

$\mathrm{H}$ ros EURIMEDIT. Viola alba Besser ssp. dehnhardtii (Ten.) W. Becker $\quad+.2$ 


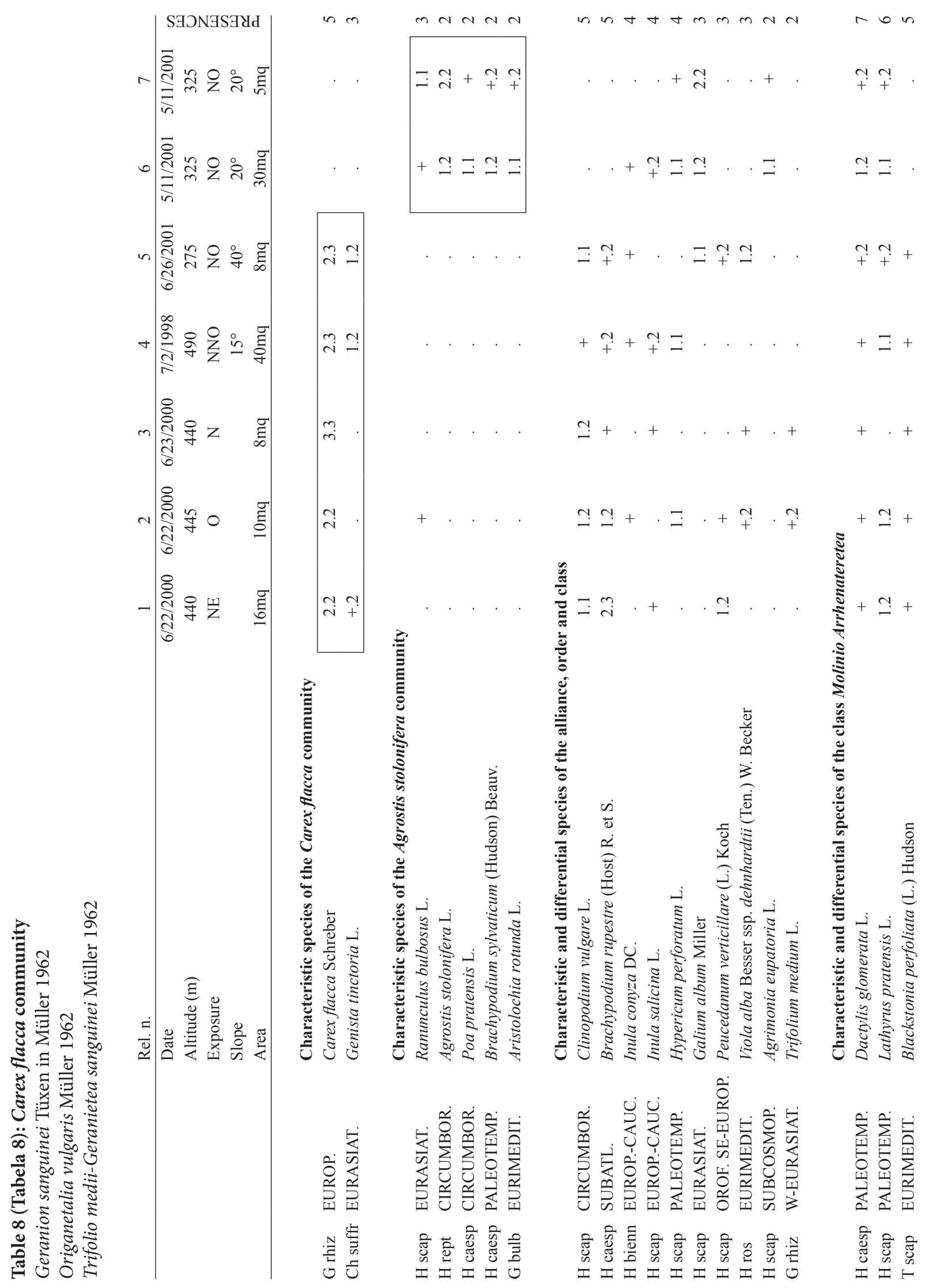




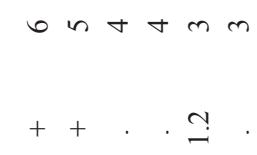

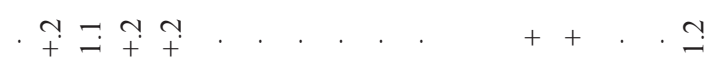

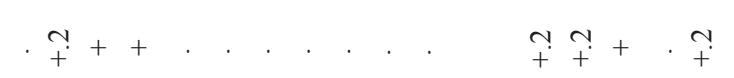

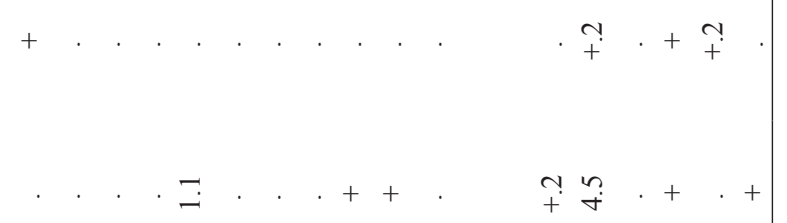

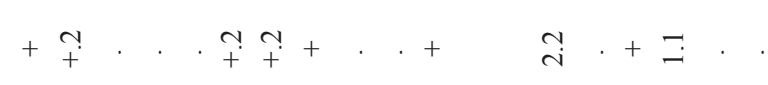

$\stackrel{+}{+}$

$\stackrel{\mathrm{N}}{\mathrm{N}} \cdot+\cdot+$

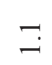

$\stackrel{-1}{2}+\frac{+}{4} \cdot \frac{+}{4}$

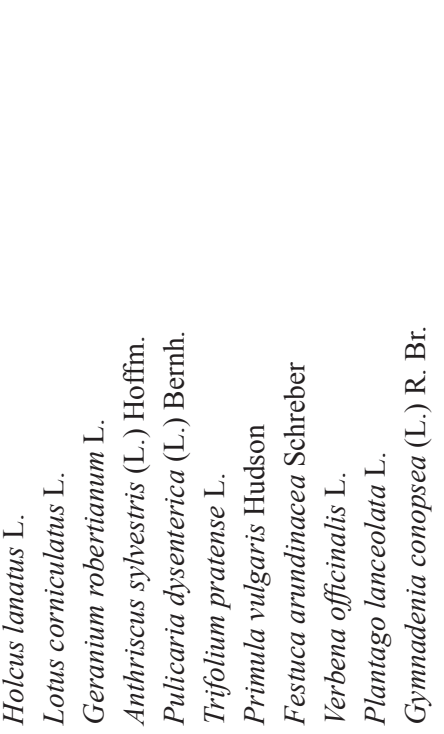

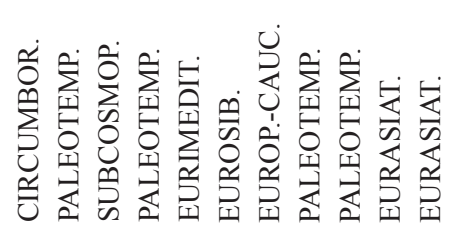

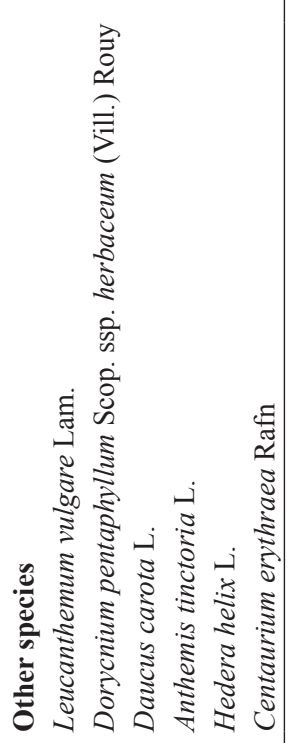

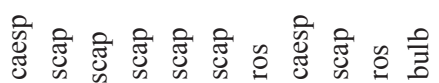

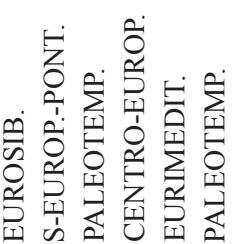

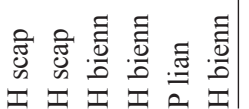


Table 9 (Tabela 9): Geum urbanum community

Galio-Alliarion petiolatae Oberdorfer \& Lohmeyer in Oberdorfer, Görs, Korneck, Lohmeyer, Müller, Philippi \& Seibert 1967

Galio aparines-Alliarietalia petiolatae Görs \& Müller, 1969.

Galio-Urticetea Passarge ex Kopecky 1969

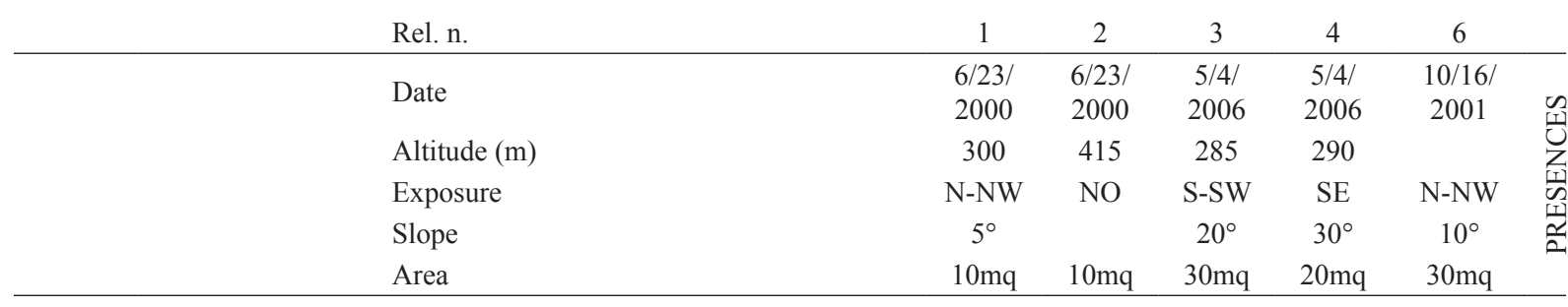

$\begin{array}{ll}\text { H scap } & \text { CIRCUMBOR. } \\ \text { H scap } & \text { PONTICA }\end{array}$

H scap PONTICA

$\begin{array}{ll}\text { H scap } & \text { EURIMEDIT. } \\ \text { H scap } & \text { PALEOTEMP. } \\ \text { H scap } & \text { EURIMEDIT. } \\ \text { T scap } & \text { EURASIAT. } \\ \text { H bienn } & \text { PALEOTEMP. }\end{array}$

Characteristic species of the Geum urbanum community

$\begin{array}{lcccccc}\text { Geum urbanum L. } & 3.3 & 1.1 & 2.2 & 1.1 & 2.3 & 5 \\ \text { Buglossoides purpurocaerulea (L.) Johnston } & 2.3 & . & 2.3 & 2.3 & . & 3\end{array}$

Characteristic and differential species of the alliance, order and class

\begin{tabular}{|c|c|c|c|c|c|}
\hline Ballota nigra $\mathrm{L}$. & 1.2 & . & 1.2 & . & . \\
\hline Anthriscus sylvestris (L.) Hoffm. & . & + & . & . & . \\
\hline Pulicaria dysenterica (L.) Bernh. & . & + & . & . & . \\
\hline Chaerophyllum temulentum $\mathrm{L}$. & 1.2 & . & . & . & 1.2 \\
\hline Alliaria petiolata (Bieb.) Cavara et Grande & . & . & . & + & . \\
\hline
\end{tabular}

Characteristic and differential species of the Trifolio-Geranietea class

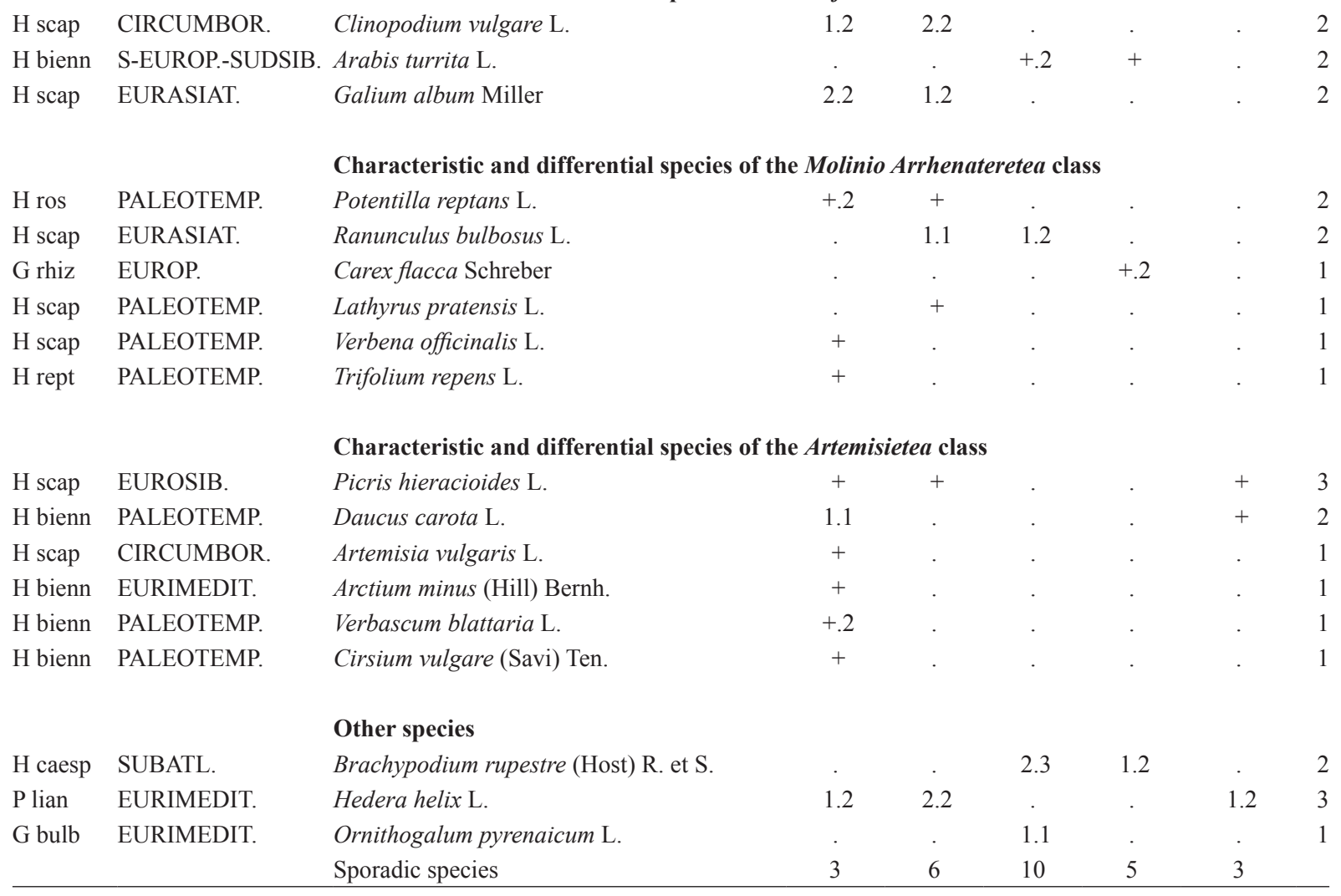


Table 10 (Tabela 10): Balloto nigrae-Melissetum romanae Brullo, Minissale, Scelsi \& Spampinato 1993

Balloto-Conion maculati Brullo in Brullo \& Marcenò 1985

Galio aparines-Alliarietalia petiolati Görs \& Müller 1969

Galio-Urticetea Passarge ex Kopecky 1969

Rel. n.

\begin{tabular}{|c|c|c|c|c|c|}
\hline 1 & 2 & 3 & 4 & 5 & \\
\hline $3 / 20 /$ & $3 / 20 /$ & $3 / 20 /$ & $10 / 16 /$ & $10 / 16 /$ & \\
\hline 2001 & 2001 & 2001 & 2001 & 2001 & 足 \\
\hline 355 & 355 & 355 & 355 & 355 & Z \\
\hline E-NE & $\mathrm{N}$ & $\mathrm{N}$ & NW & $\mathrm{N}$ & II \\
\hline $30^{\circ}$ & $20^{\circ}$ & $10^{\circ}$ & $10^{\circ}$ & $20^{\circ}$ & $\vec{a}$ \\
\hline $50 \mathrm{mq}$ & $50 \mathrm{mq}$ & $30 \mathrm{mq}$ & $60 \mathrm{mq}$ & $50 \mathrm{mq}$ & \\
\hline
\end{tabular}

Characteristic species of the association

\begin{tabular}{|c|c|c|c|c|c|c|c|c|}
\hline H scap & EURIMEDIT. & Ballota nigra $\mathrm{L}$. & 1.1 & 2.3 & 1.1 & 3.3 & 1.2 & 5 \\
\hline & & \multicolumn{6}{|c|}{ Differential species of Cruciata laevipes variant } & \\
\hline H scap & EURASIAT. & Cruciata laevipes Opiz & . & . & . & . & 3.4 & 1 \\
\hline \multicolumn{8}{|c|}{ Characteristic and differential species of the alliance, order and class } & \\
\hline H scap & SUBCOSMOP. & Urtica dioica $\mathrm{L}$. & +.2 & +.2 & + & . & +.2 & 4 \\
\hline T scap & EURASIAT. & Chaerophyllum temulentum $\mathrm{L}$. & +.2 & + & + & . & . & 3 \\
\hline T scap & EURASIAT. & Galium aparine $\mathrm{L}$. & +.2 & 2.2 & 1.1 & . & . & 3 \\
\hline H scap & E-MEDIT.-MONT & Lamium garganicum L. ssp. garganicum & 3.4 & 2.3 & 5.5 & . & . & 3 \\
\hline H bienn & PALEOTEMP. & Alliaria petiolata (Bieb.) Cavara et Grande & +.2 & +.2 & . & . & . & 2 \\
\hline
\end{tabular}

\begin{tabular}{|c|c|c|c|c|c|c|c|c|}
\hline H scap & CIRCUMBOR. & Artemisia vulgaris L. & + & + & + & . & + & 4 \\
\hline $\mathrm{H}$ bienn & PALEOTEMP. & Daucus carota L. & . & . & + & + & + & 3 \\
\hline H scap & EUROSIB. & Picris hieracioides L. & . & . & . & 1.1 & 1.1 & 2 \\
\hline T scap & EURIMEDIT. & Picris echioides L. & . & . & . & + & +.2 & 2 \\
\hline $\mathrm{H}$ bienn & MEDIT.-TURAN. & Carduus pycnocephalus L. & . & 1.1 & 1.1 & . & . & 2 \\
\hline G rhiz & PALEOTEMP. & Convolvulus arvensis $\mathrm{L}$. & . & . & . & 1.1 & . & 1 \\
\hline \multirow[t]{2}{*}{$\mathrm{H}$ bienn } & EURIMEDIT. & Arctium minus (Hill) Bernh. & . & 1.2 & . & . & . & 1 \\
\hline & & Other species & & & & & & \\
\hline T rept & COSMOP. & Stellaria media (L.) Vill. & +.2 & 1.1 & 1.2 & 1.2 & 1.2 & 5 \\
\hline G rhiz & STENOMEDIT. & Arum italicum Miller & 1.2 & + & 1.1 & + & 1.1 & 5 \\
\hline T scap & PALEOTEMP. & Mercurialis annua L. & 1.1 & 1.1 & + & . & + & 4 \\
\hline H scap & $\begin{array}{l}\text { EURIMEDIT.- } \\
\text { MACARON. }\end{array}$ & Parietaria diffusa M. et K. & 2.3 & +.2 & 1.2 & $(+.2)$ & . & 4 \\
\hline $\mathrm{H}$ bienn & PALEOTEMP. & Silene alba (Miller) Krause & + & +.2 & . & 1.1 & 2.3 & 4 \\
\hline P lian & EURIMEDIT. & Hedera helix $\mathrm{L}$. & +.2 & + & +.2 & . & . & 3 \\
\hline NP & EURIMEDIT. & Rubus ulmifolius Schott & + & + & + & . & . & 3 \\
\hline T scap & PALEOTEMP. & Geranium rotundifolium L. & . & + & +.2 & +.2 & . & 3 \\
\hline T scap & AVV. & Conyza canadensis (L.) Cronq. & $(+.2)$ & . & . & 1.1 & + & 3 \\
\hline T scap & EURASIAT. & Veronica hederifolia $\mathrm{L}$. & 1.2 & 1.2 & . & +.2 & . & 3 \\
\hline T scap & PALEOTEMP. & Fumaria officinalis L. ssp officinalis & + & +.2 & . & . & . & 2 \\
\hline \multirow[t]{2}{*}{ H scap } & EURASIAT. & Ranunculus bulbosus L. & . & . & . & + & 1.2 & 2 \\
\hline & & Sporadic species & 4 & 4 & 1 & 8 & 8 & \\
\hline
\end{tabular}


Table 11 (Tabela 11): Centaureo bracteatae-Brometum erecti Biondi, Ballelli, Allegrezza, Guitian \& Taffetani 1986 Polygalo mediterraneae-Bromenion erecti Biondi, Allegrezza \& Zuccarello 2005

Bromion erecti Koch 1926

\begin{tabular}{|c|c|c|c|c|c|c|c|}
\hline & & Rel. n. & 1 & 2 & 3 & 4 & 5 \\
\hline & & Date & $\begin{array}{c}22 / 06 / \\
2000\end{array}$ & $\begin{array}{c}22 / 06 / \\
2000\end{array}$ & $\begin{array}{c}23 / 06 / \\
2000\end{array}$ & $\begin{array}{c}22 / 06 / \\
2000\end{array}$ & $\begin{array}{c}01 / 08 / \\
2001\end{array}$ \\
\hline & & Altitude (m) & 495 & 510 & 380 & 545 & 500 \\
\hline & & Exposure & $\mathrm{E}$ & $\mathrm{NE}$ & $\mathrm{O}$ & $\mathrm{N}$ & $\mathrm{E}$ \\
\hline & & Slope & $15^{\circ}$ & $30^{\circ}$ & $40^{\circ}$ & $40^{\circ}$ & $40^{\circ}$ \\
\hline & & Area & $50 \mathrm{mq}$ & & $30 \mathrm{mq}$ & $50 \mathrm{mq}$ & $50 \mathrm{mq}$ \\
\hline & & Coverage & 100 & 100 & 100 & 100 & 100 \\
\hline & & \multicolumn{6}{|c|}{ Characteristic and differential species of the association } \\
\hline H scap & SE-EUROP. & $\begin{array}{l}\text { Centaurea jacea L. ssp. gaudini (Boiss. \& Reut.) } \\
\text { Gremli }\end{array}$ & 1.2 & 1.2 & 1.2 & +.2 & 1.1 \\
\hline H scap & EURASIAT. & Galium mollugo L. ssp. erectum Syme & . & +.2 & . & . & . \\
\hline H caesp & EURASIAT. & Centaurea scabiosa L. ssp. scabiosa & . & 1.1 & . & . & . \\
\hline & & \multicolumn{6}{|l|}{ Differential species of the Agropyron repens variant } \\
\hline G rhiz & CIRCUMBOR. & Elymus repens (L.) Gould ssp. repens & . & . & . & . & . \\
\hline G rhiz & PALEOTEMP. & Tussilago farfara $\mathrm{L}$. & . & . & + & . & . \\
\hline H caesp & EURASIAT. & Festuca pratensis Hudson & . & . & . & . & . \\
\hline & & \multicolumn{6}{|c|}{ Differential species of the Asperula purpurea variant } \\
\hline H scap & SE-EUROP-PONTICA & Eryngium amethystinum $\mathrm{L}$. & . & . & . & . & . \\
\hline Ch suffr & EURIMEDIT. & Teucrium chamaedrys L. & . & . & . & . & 1.2 \\
\hline Ch suffr & OROF. SE-EUROP. & Asperula purpurea (L.) Ehrend. & . & . & . & . & . \\
\hline Ch suffr & S-EUROP. & Helichrysum italicum (Roth) Don & . & . & . & . & . \\
\hline \multirow[t]{2}{*}{ H scap } & EURIMEDIT. & Ononis pusilla L. ssp. pusilla & . & . & . & . & . \\
\hline & & \multicolumn{6}{|c|}{ Characteristic and differential species of the suballiance, alliance and suborder } \\
\hline H caesp & PALEOTEMP. & Dactylis glomerata L. & 1.1 & 1.1 & + & 1.1 & + \\
\hline H scap & S-EUROP.-PONT. & Dorycnium herbaceum Vill. & 1.2 & 1.2 & 1.2 & 1.2 & +.2 \\
\hline H caesp & SUBATL. & Brachypodium rupestre (Host) R. et S. & 2.3 & 1.2 & 1.2 & 1.2 & +.2 \\
\hline H caesp & EUROSIB. & Briza media $\mathrm{L}$. & +.2 & + & 1.1 & +.2 & +.2 \\
\hline $\mathrm{H}$ bienn & PALEOTEMP. & Daucus carota $\mathrm{L}$. & + & . & + & . & + \\
\hline H scap & PALEOTEMP. & Lotus corniculatus L. & +.2 & +.2 & . & . & +.2 \\
\hline H bienn & PALEOTEMP. & Centaurium erythraea Rafn & + & + & . & . & + \\
\hline H scap & EUROSIB. & Leucanthemum vulgare Lam. ssp. vulgare & +.2 & +.2 & 1.2 & . & . \\
\hline Ch suffr & EURIMEDIT. & Ononis spinosa $\mathrm{L}$. & . & + & . & . & 1.2 \\
\hline $\mathrm{H}$ bienn & EURIMEDIT. & Linum bienne Miller & . & . & . & . & . \\
\hline Ch suffr & EURASIAT. & Genista tinctoria L. & . & +.2 & . & +.2 & . \\
\hline T scap & EURIMEDIT. & Blackstonia perfoliata (L.) Hudson & + & + & + & . & + \\
\hline H scap & PALEOTEMP. & Hypericum perforatum L. & + & + & . & . & . \\
\hline H scap & ENDEM. ALP. & Centaurea nigrescens Willd. & . & . & . & . & . \\
\hline $\mathrm{H}$ ros & EURASIAT. & Plantago lanceolata $\mathrm{L}$. & + & . & . & . & . \\
\hline H scap & EUROSIB. & Trifolium pratense $\mathrm{L}$. & + & + & . & . & . \\
\hline H scap & MEDIT.-MONT. & Onobrychis viciifolia Scop. & . & . & . & . & . \\
\hline $\mathrm{H}$ bienn & CENTRO-EUROP. & Cota tinctoria (L.) J. Gay & + & + & . & . & . \\
\hline G bulb & EURASIAT. & Gymnadenia conopsea (L.) R. Br. & . & . & . & + & . \\
\hline H scap & EURASIAT. & Ranunculus bulbosus L. & . & . & . & . & . \\
\hline H scap & EURIMEDIT. & Polygala nicaeensis Risso ssp. mediterranea & . & . & . & . & . \\
\hline G bulb & EURIMEDIT. & Anacamptis pyramidalis (L.)L.C.Rich. & . & . & . & . & . \\
\hline T scap & PALEOTEMP. & Medicago lupulina $\mathrm{L}$. & +.2 & . & . & . & . \\
\hline
\end{tabular}


Leucanthemo vulgaris-Bromenalia erecti Biondi, Ballelli, Allegrezza \& Zuccarello 1995

Brometalia erecti Br.-Bl. 1936

Festuco-Brometea Br.-Bl. \& Tüxen ex Br.-Bl.1949

\begin{tabular}{|c|c|c|c|c|c|c|c|c|c|c|c|c|c|c|c|}
\hline 6 & 7 & 8 & 9 & 10 & 11 & 12 & 13 & 14 & 15 & 16 & 17 & 18 & 19 & 20 & \\
\hline $\begin{array}{c}10 / 10 / \\
2006\end{array}$ & $\begin{array}{c}10 / 10 / \\
2006\end{array}$ & $\begin{array}{c}10 / 10 / \\
2006\end{array}$ & $\begin{array}{c}10 / 10 / \\
2006\end{array}$ & $\begin{array}{c}10 / 10 / \\
2006\end{array}$ & $\begin{array}{c}23 / 06 / \\
2000\end{array}$ & $\begin{array}{c}23 / 06 / \\
2000\end{array}$ & $\begin{array}{c}23 / 06 / \\
2000\end{array}$ & $\begin{array}{c}18 / 06 / \\
1998\end{array}$ & $\begin{array}{c}11 / 05 / \\
2001\end{array}$ & $\begin{array}{c}11 / 05 / \\
2001\end{array}$ & $\begin{array}{c}10 / 10 / \\
2006\end{array}$ & $\begin{array}{c}10 / 10 / \\
2006\end{array}$ & $\begin{array}{c}10 / 10 / \\
2006\end{array}$ & $\begin{array}{c}10 / 10 / \\
2006\end{array}$ & \\
\hline 457 & 522 & 530 & 540 & 520 & 375 & 380 & 370 & 280 & 320 & 320 & 560 & 530 & 518 & 520 & \\
\hline $\mathrm{NE}$ & NW & $\mathrm{N}$ & NW & $\mathrm{N}$ & $\mathrm{NO}$ & $\mathrm{N}$ & $\mathrm{O}$ & $\mathrm{O}$ & E & E & $\mathrm{N}$ & $\mathrm{NE}$ & NW & SE & II \\
\hline 15 & $20^{\circ}$ & $40^{\circ}$ & $20^{\circ}$ & $30^{\circ}$ & $30^{\circ}$ & $30^{\circ}$ & $40^{\circ}$ & $30^{\circ}$ & $35^{\circ}$ & $35^{\circ}$ & 30 & 30 & 10 & 10 & \\
\hline 30 & $30 \mathrm{mq}$ & $30 \mathrm{mq}$ & $30 \mathrm{mq}$ & $30 \mathrm{mq}$ & $50 \mathrm{mq}$ & $60 \mathrm{mq}$ & $30 \mathrm{mq}$ & $40 \mathrm{mq}$ & $50 \mathrm{mq}$ & $40 \mathrm{mq}$ & 30 & 30 & 30 & 30 & \\
\hline 100 & 100 & 100 & 100 & 100 & 100 & 100 & 100 & 100 & 100 & 100 & 100 & 100 & 100 & 100 & \\
\hline
\end{tabular}

\begin{tabular}{|c|c|c|c|c|c|c|c|c|c|c|c|c|c|}
\hline $1.2+.2$ & +.2 & 1.2 & +.2 & . & + & . & 1.1 & 1.1 & + & 1.2 & 1.2 & +.2 & + \\
\hline 1.2 & . & . & . & . & . & . & . & +.2 & + & . & . & . & . \\
\hline . & . & . & 1.2 & . & . & . & . & . & . & . & . & 2.2 & . \\
\hline . & . & . & . & 2.2 & +.2 & 1.2 & + & +.2 & +.2 & +.2 & . & . & . \\
\hline . & . & . & . & 1.2 & 1.2 & 2.2 & + & . & . & . & . & . & . \\
\hline . & . & . & . & . & . & . & 1.2 & . & . & . & . & . & . \\
\hline
\end{tabular}

\begin{tabular}{|cccc|c}
\hline. & 1.1 & + & + & 6 \\
+.2 & 1.2 & +.2 & 1.2 & 5 \\
+.2 & 1.2 & 1.2 & 1.2 & 4 \\
1.2 & 2.3 &. & + & 3 \\
. &. & + & 1.1 & 2
\end{tabular}

\begin{tabular}{|c|c|c|c|c|c|c|c|c|c|c|c|c|c|c|c|}
\hline 1.1 & 1.1 & 1.1 & +.2 & +.2 & + & . & + & 1.1 & 1.1 & 2.2 & 1.1 & 1.1 & + & 1.2 & 19 \\
\hline+ & 1.2 & 2.3 & 2.3 & 1.2 & 1.2 & 2.2 & 1.2 & 2.3 & 1.2 & + & . & 2.3 & 1.2 & +.2 & 19 \\
\hline 2.3 & 2.3 & 1.2 & 1.2 & 1.2 & 1.2 & 1.1 & 1.2 & 1.2 & . & . & +.2 & 1.2 & +.2 & 2.3 & 18 \\
\hline+ & 1.1 & 1.1 & 1.1 & 1.1 & 1.1 & 1.1 & +.2 & 1.1 & . & . & . & 1.1 & 1.1 & + & 17 \\
\hline+ & + & + & 1.1 & 1.1 & . & . & + & . & . & . & 1.1 & + & + & + & 13 \\
\hline . & 1.2 & +.2 & +.2 & +.2 & +.2 & +.2 & . & +.2 & 1.2 & +.2 & . & . & . & . & 12 \\
\hline+ & + & + & . & + & + & . & . & . & . & . & 1.1 & + & + & + & 12 \\
\hline . & . & . & . & . & +.2 & + & +.2 & + & . & . & . & 1.1 & + & +.2 & 10 \\
\hline . & . & . & . & . & + & 1.2 & . & . & 1.2 & 1.2 & . & 1.2 & +.2 & . & 8 \\
\hline . & 1.1 & 1.1 & +.2 & 1.1 & . & . & . & . & . & . & 1.2 & 1.2 & + & + & 8 \\
\hline . & . & . & . & . & . & 1.1 & . & 1.2 & . & . & . & +.2 & +.2 & + & 7 \\
\hline . & . & . & + & + & + & . & . & . & . & . & . & . & . & . & 7 \\
\hline+ & + & + & . & . & . & . & . & . & . & . & . & . & . & + & 6 \\
\hline . & . & . & . & . & + & . & . & . & . & . & +.2 & 1.1 & + & + & 5 \\
\hline . & . & . & . & . & . & . & . & . & . & . & 1.1 & + & + & + & 5 \\
\hline . & . & + & . & . & . & . & . & . & +.2 & . & . & . & . & . & 4 \\
\hline . & . & . & . & . & . & . & . & . & . & . & . & 1.1 & 1.2 & 1.1 & 3 \\
\hline . & . & $\cdot$ & . & . & . & . & . & . & . & . & . & . & . & . & 2 \\
\hline . & . & + & . & . & . & . & . & . & . & . & . & . & . & . & 2 \\
\hline . & . & . & . & . & . & . & . & . & +.2 & + & . & . & . & . & 2 \\
\hline . & . & . & . & . & . & . & . & +.2 & . & . & . & . & . & . & 1 \\
\hline . & . & $\cdot$ & . & . & . & . & $\cdot$ & + & $\cdot$ & . & $\cdot$ & . & . & . & 1 \\
\hline . & . & . & . & . & . & . & . & . & . & . & . & . & . & . & 1 \\
\hline
\end{tabular}




\begin{tabular}{|c|c|c|c|c|c|c|c|}
\hline & & Rel. n. & 1 & 2 & 3 & 4 & 5 \\
\hline \multicolumn{8}{|c|}{ Characteristic and differential species of the order and class } \\
\hline H caesp & PALEOTEMP. & Bromus erectus Hudson & 3.3 & 4.4 & 4.4 & 3.4 & 3.3 \\
\hline H caesp & EURIMEDIT. & Phleum bertolonii DC. & +.2 & + & +.2 & . & . \\
\hline Ch suffr & EURIMEDIT. & Dorycnium hirsutum (L.) Ser. & . & . & . & + & 1.1 \\
\hline H scap & PALEOTEMP. & Dianthus balbisii Ser. ssp. liburnicus (Bartl.) Pign. & . & . & + & + & 1.1 \\
\hline H scap & OROF. S-EUROP. & Linum viscosum $\mathrm{L}$. & + & +.2 & + & 1.2 & + \\
\hline T scap & EURIMEDIT. & Odontites lutea (L.) Clairv. & . & . & . & . & . \\
\hline H scap & EUROSIB. & Achillea millefolium & . & . & . & . & . \\
\hline H scap & EURIMEDIT. & Eryngium campestre L. & . & . & . & . & + \\
\hline H scap & PALEOTEMP. & Sanguisorba minor Scop. & . & . & . & . & + \\
\hline Ch suffr & EUROP.-CAUC. & Helianthemum nummularium (L.) Miller & . & . & . & . & . \\
\hline H scap & EURASIAT. & Medicago sativa $\mathrm{L}$. & . & . & . & . & . \\
\hline H bienn & EURIMEDIT. & Tragopogon porrifolius L. & . & . & . & . & . \\
\hline H bienn & SE-EUROP. & Arabis sagittata (Bertol.) DC. & . & . & . & . & . \\
\hline T scap & PALEOTEMP. & Trifolium campestre Schreber & . & . & . & . & . \\
\hline \multirow[t]{2}{*}{$\mathrm{H}$ ros } & EUROP.-CAUC. & Hieracium pilosella L. & . & . & . & . & . \\
\hline & & \multicolumn{6}{|c|}{ Characteristic and differential species of the Artemisietea class } \\
\hline H scap & EURASIAT. & Senecio erucifolius L. & 1.1 & . & +.2 & . & + \\
\hline H scap & EURIMEDIT. & Dittrichia viscosa (L.) Greuter & + & . & +.2 & . & . \\
\hline H scap & STENOMEDIT. & Carlina corymbosa $\mathrm{L}$. & + & + & . & . & . \\
\hline H scap & EUROSIB. & Picris hieracioides L. & + & . & + & . & . \\
\hline H bienn & PALEOTEMP. & Cirsium vulgare (Savi) Ten. & . & . & . & . & . \\
\hline H scap & PALEOTEMP. & Cichorium intybus L. & . & . & . & . & . \\
\hline G rhiz & PALEOTEMP. & Convolvulus arvensis $\mathrm{L}$. & . & . & . & . & . \\
\hline H scap & CIRCUMBOR. & Artemisia vulgaris L. & . & . & . & . & . \\
\hline \multirow[t]{2}{*}{ H bienn } & MEDIT.-TURAN. & Carduus pycnocephalus L. ssp. pycnocephalus & . & . & . & . & . \\
\hline & & \multicolumn{6}{|c|}{ Characteristic and differential species of the Molinio-Arrhenatheretea class } \\
\hline G rhiz & EUROP. & Carex flacca Schreber ssp. serrulata (Biv.) Greuter & + & . & . & 1.1 & 1.2 \\
\hline H scap & EUROP.-CAUC. & Inula salicina $\mathrm{L}$. & +.2 & +.2 & . & +.2 & 1.2 \\
\hline H caesp & CIRCUMBOR. & Poa pratensis L. & + & . & . & . & . \\
\hline H scap & PALEOTEMP. & Lathyrus pratensis L. & + & . & . & . & . \\
\hline H caesp & CIRCUMBOR. & Holcus lanatus L. & + & + & . & . & . \\
\hline \multirow[t]{2}{*}{ T scap } & CIRCUMBOR. & Rhinanthus minor L. & 1.1 & + & . & . & . \\
\hline & & Other species & & & & & \\
\hline H scap & EURIMEDIT. & Pulicaria dysenterica (L.) Bernh. & . & . & . & . & . \\
\hline H scap & CIRCUMBOR. & Clinopodium vulgare L. & . & . & . & + & + \\
\hline H scap & CIRCUMBOR. & Solidago virgaurea L. & . & . & . & . & . \\
\hline H scap & W-STENOMEDIT. & Sulla coronaria (L.) Medik. & . & . & + & . & . \\
\hline H scap & PALEOTEMP. & Silene vulgaris (Moench) Garcke & . & + & . & . & + \\
\hline P lian & EUROP.-CAUC. & Clematis vitalba $\mathrm{L}$. & . & . & . & . & . \\
\hline H scap & OROF. SE-EUROP. & Peucedanum verticillare (L.) Koch & . & . & . & + & + \\
\hline NP & EURIMEDIT. & Rubus ulmifolius Schott & . & . & . & . & . \\
\hline G bulb & EURIMEDIT. & Muscari comosum (L.) Mill. & . & . & . & . & . \\
\hline H scap & SUBCOSMOP. & Agrimonia eupatoria L. & . & . & . & . & . \\
\hline T scap & EURIMEDIT.-TURAN. & Vicia sativa $\mathrm{L}$. & . & . & . & . & . \\
\hline$P$ caesp & PALEOTEMP. & Crataegus monogyna Jacq. & . & . & . & . & . \\
\hline G rhiz & COSMOPOL. & Pteridium aquilinum (L.) Kuhn & . & . & . & + & 1.1 \\
\hline G bulb & OROF. C-EUROP. & Lilium bulbiferum L. ssp. croceum (Chaix) Baker & . & . & . & + & + \\
\hline H scap & EUROSIB. & Peucedanum cervaria (L.) Lepeyr. & . & . & . & . & . \\
\hline G rhiz & CIRCUMBOR. & Equisetum telmateja Ehrh. & . & . & . & . & . \\
\hline \multirow[t]{2}{*}{ H scap } & ENDEM. & Scabiosa uniseta Savi & . & . & . & . & . \\
\hline & & Sporadic species & 1 & 1 & 2 & 0 & 0 \\
\hline
\end{tabular}




\begin{tabular}{|c|c|c|c|c|c|c|c|c|c|c|c|c|c|c|c|}
\hline 6 & 7 & 8 & 9 & 10 & 11 & 12 & 13 & 14 & 15 & 16 & 17 & 18 & 19 & 20 & \\
\hline 2.3 & 3.4 & 2.3 & 3.4 & 2.3 & 2.2 & 4.4 & 2.3 & 3.4 & 3.3 & 3.3 & 4.4 & 3.3 & 3.4 & 3.4 & 20 \\
\hline 1.1 & 1.1 & +.2 & 1.1 & 1.1 & . & +.2 & . & 1.2 & . & . & . & + & + & + & 13 \\
\hline . & . & + & 1.2 & +.2 & +.2 & . & + & . & 1.1 & . & . & +.2 & +.2 & + & 11 \\
\hline . & . & . & . & +.2 & + & +.2 & + & . & . & . & . & 1.1 & 1.1 & 1.1 & 10 \\
\hline . & . & . & . & . & + & +.2 & +.2 & 1.1 & . & . & . & . & . & . & 9 \\
\hline+ & . & . & +.2 & + & . & . & . & . & . & . & +.2 & + & + & +.2 & 7 \\
\hline+ & + & + & . & . & . & . & . & . & . & . & . & 1.2 & + & + & 6 \\
\hline . & . & . & . & . & . & + & . & . & . & . & . & + & + & . & 4 \\
\hline . & . & . & . & . & . & . & . & . & . & . & . & . & + & 1.1 & 3 \\
\hline . & . & . & . & . & . & . & . & +.2 & . & . & . & . & +.2 & +.2 & 3 \\
\hline . & + & + & . & . & . & . & . & . & . & . & + & . & . & . & 3 \\
\hline . & . & . & . & . & . & + & . & . & . & + & . & . & . & . & 2 \\
\hline . & . & . & . & . & . & . & . & . & . & . & . & . & + & + & 2 \\
\hline . & . & . & . & . & . & . & . & . & . & + & . & . & . & . & 1 \\
\hline . & . & . & . & . & . & . & . & . & . & . & . & . & . & 1.2 & 1 \\
\hline
\end{tabular}

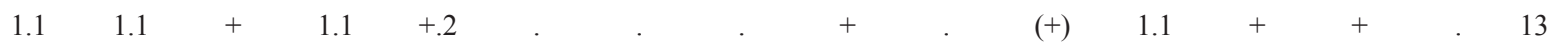

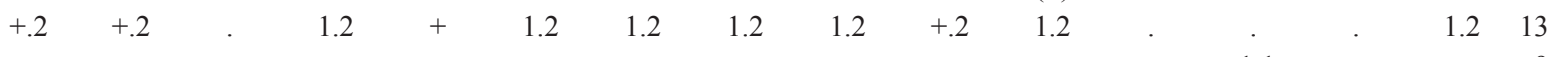

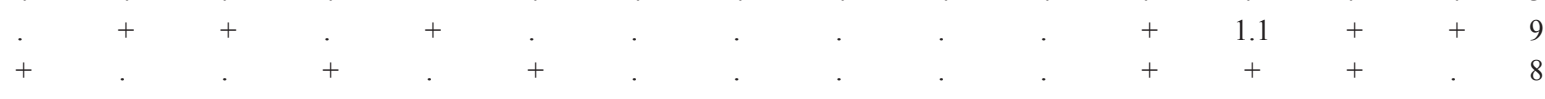

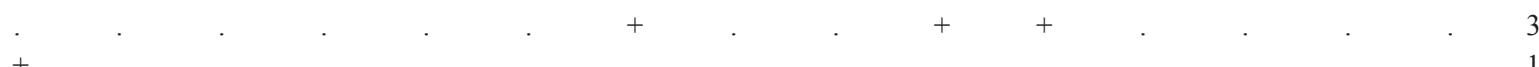

$$
\begin{aligned}
& +2
\end{aligned}
$$

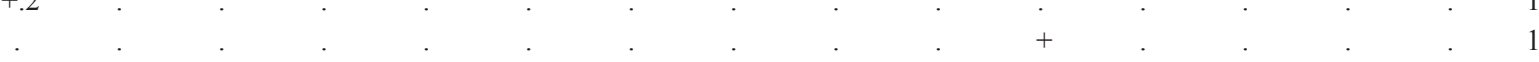

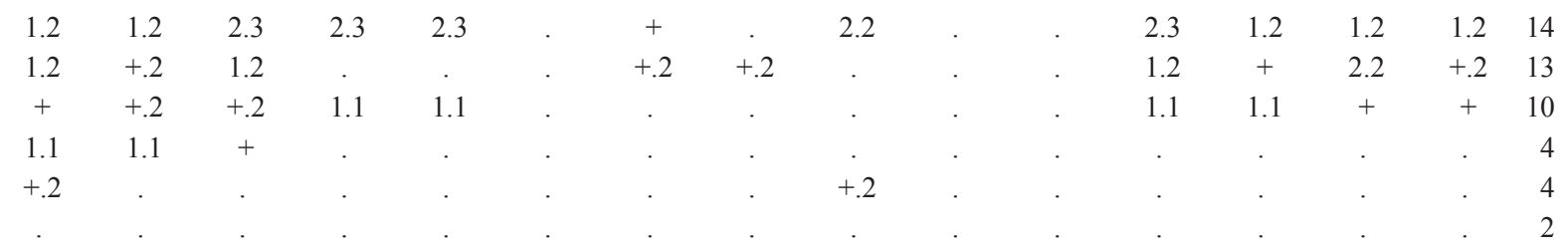

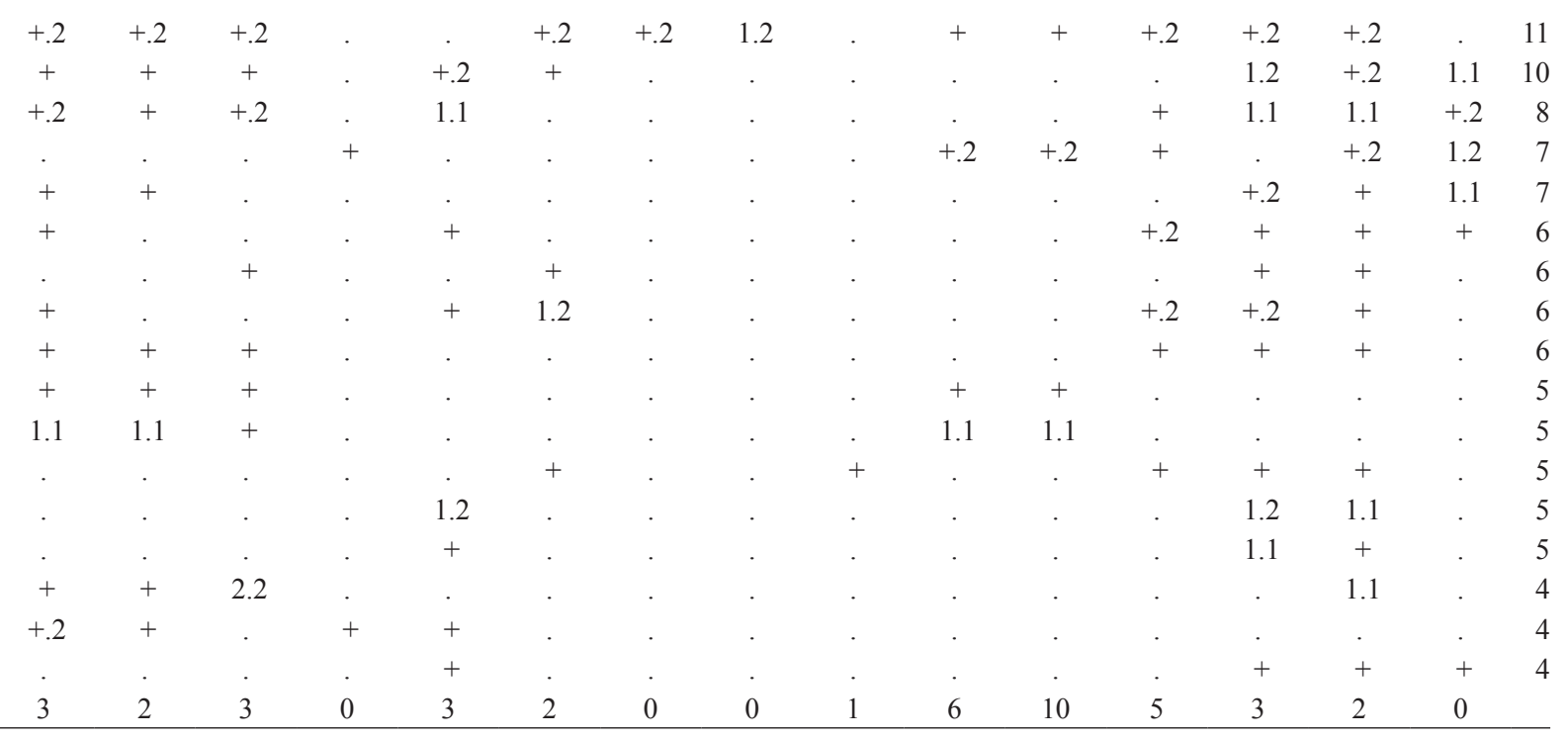




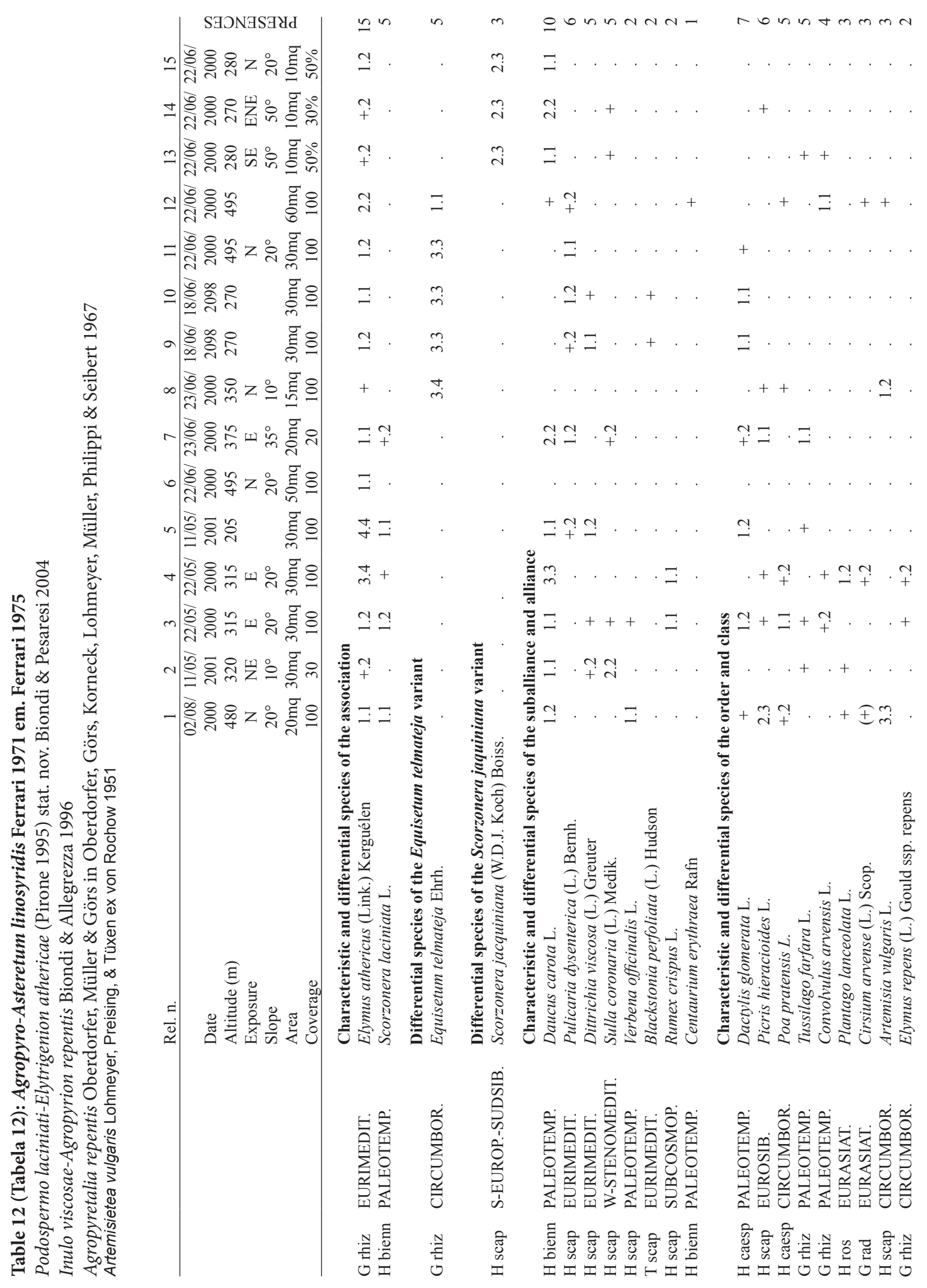



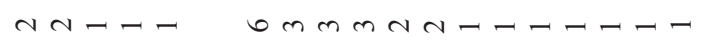

$\stackrel{m}{i}$

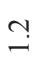
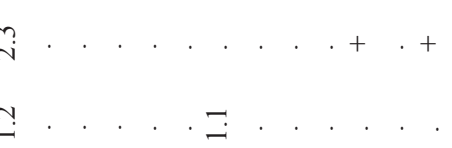

$\cdot \stackrel{+}{+}$

$\stackrel{-1}{\text { Nִ }}$

$\cdot+\stackrel{+}{+}$

$\stackrel{\sim}{9}$
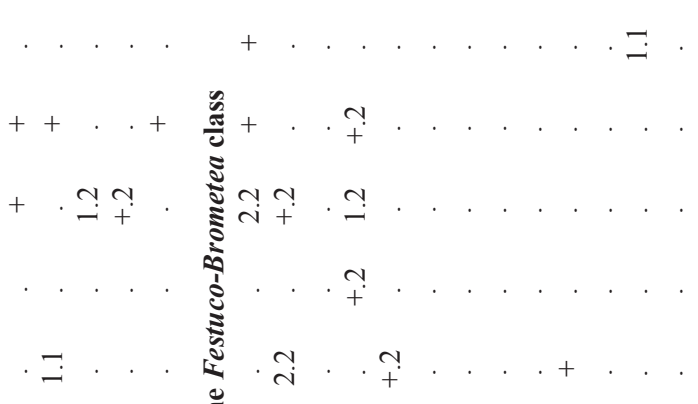

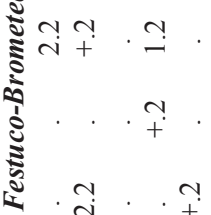
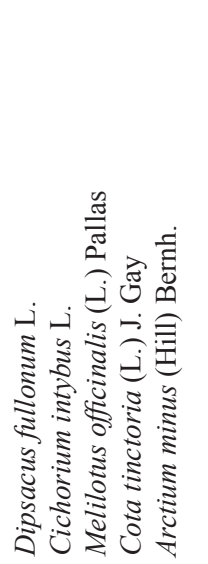

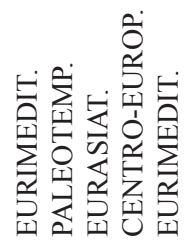

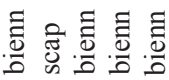

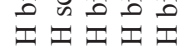

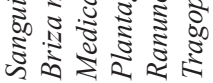

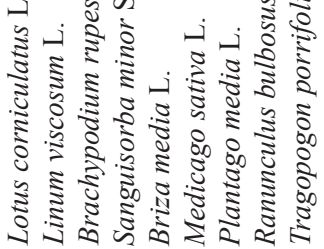

定 完

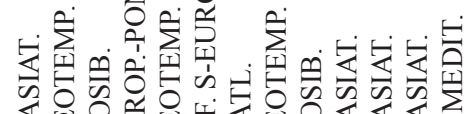

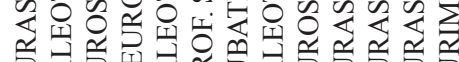

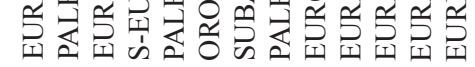

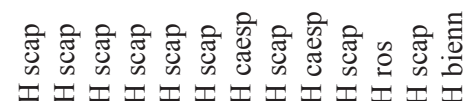

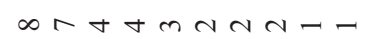

ำ

$\stackrel{\text { กิ }}{\stackrel{4}{4}}$

กำ

ำ

min $\stackrel{4}{+}$

$\exists$ 곡

กุบ

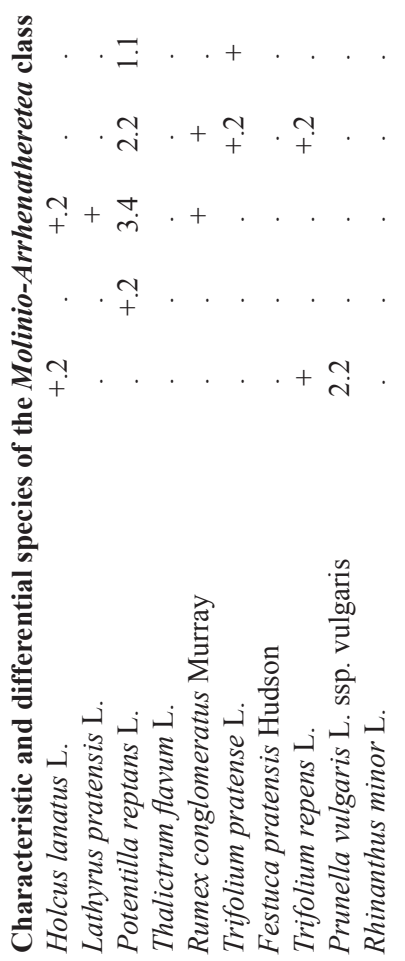

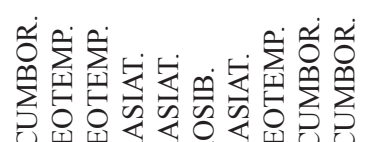

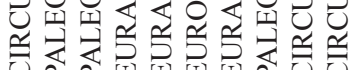

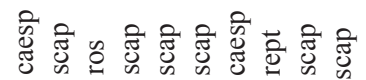

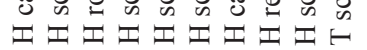

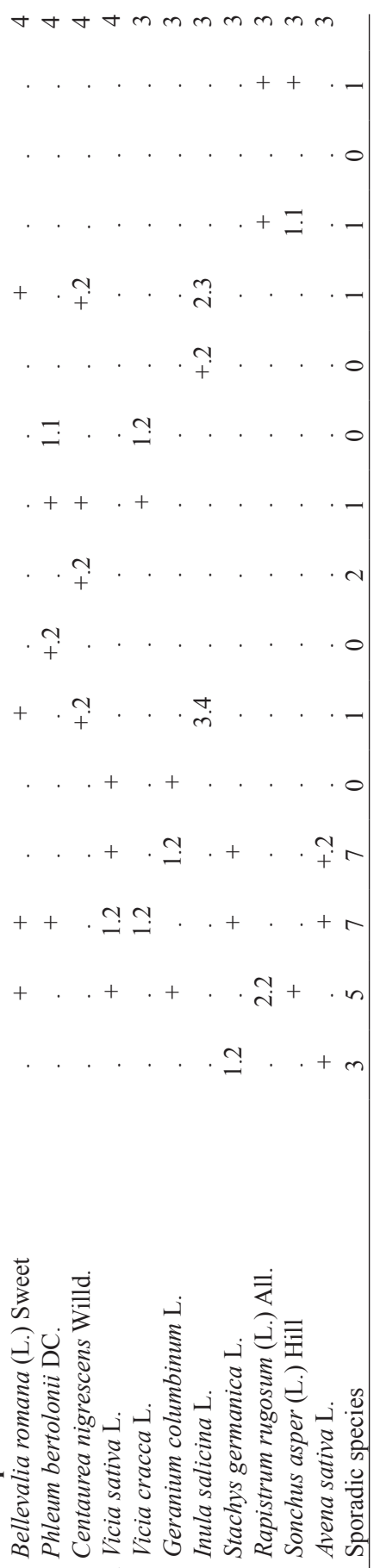

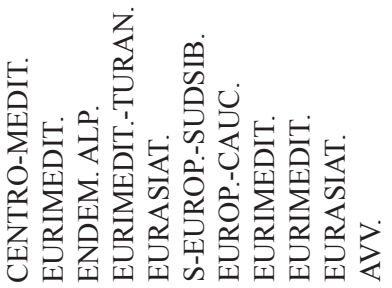

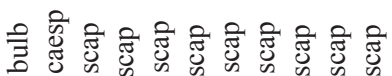

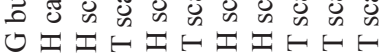


Table 13 (Tabela 13): Vicio variae-Hainardetum cylindricae ass. nova (type rel. n.2)

Helianthemion guttati Br.-Bl. in Br.-Bl., Molinier \& Wagner 1940

Helianthemetalia guttati Br.-Bl. in Br.-Bl., Molinier \& Wagner 1940 em. Rivas-Martínez 1978

Helianthemetea guttati (Br.-Bl. in Br.-Bl., Roussine et Nègre 1952) Rivas Goday et Rivas-Martínez 1963 em. RivasMartínez 1978

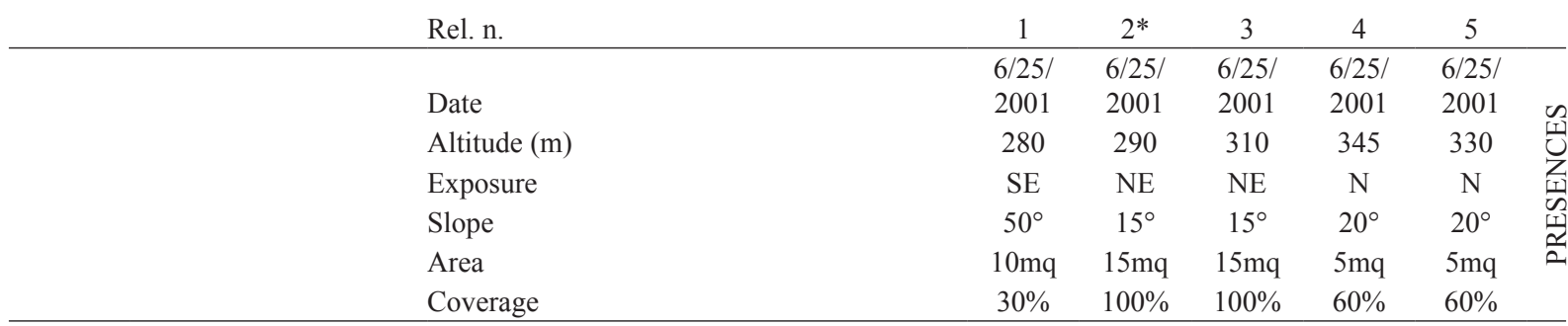

$\begin{array}{ll}\text { T scap } & \text { EURIMEDIT. } \\ \text { T scap } & \text { EURIMEDIT. } \\ \text { T scap } & \text { SUBCOSMOP. } \\ \text { H bienn } & \text { PALEOTEMP. } \\ & \\ \text { T scap } & \text { S-MEDIT. } \\ \text { T scap } & \text { S-EUROP.-SUDSIB. } \\ \text { T scap } & \text { STENOMEDIT. } \\ \text { T scap } & \text { EURIMEDIT. } \\ \text { T scap } & \text { STENOMEDIT. } \\ \text { T scap } & \text { PALEOTEMP. }\end{array}$

Characteristic and differential species of the association

$\begin{array}{lcccccr}\text { Hainardia cylindrica } \text { (Willd.) Greuter } & 2.3 & 2.2 & +.2 & 3.3 & 2.2 & 4 \\ \text { Vicia villosa } \text { Roth ssp. varia (Host) Corb. } & . & +.2 & 1.2 & + & + & 4 \\ \text { Bromus hordeaceus L. } & . & 1.1 & +.2 & +.2 & + & 4 \\ \text { Scorzonera laciniata } \text { L. } & . & +.2 & 1.1 & . & . & 2\end{array}$

Characteristic and differential species of the alliance, order and class

Melilotus sulcata Desf.

Trifolium echinatum Bieb.

Linum corymbulosum Rchb.

$\begin{array}{lll}\cdot & + & + \\ + & +.2 & \\ + & +.2 & + \\ & +.2 & 1.2\end{array}$

Trifolium stellatum L.

Hypochoeris achyrophorus $\mathrm{L}$.

1.1

Trifolium arvense $\mathrm{L}$.

1.2

Characteristic and differential species of Artemisietea class

$\begin{array}{ll}\text { T scap } & \text { EURIMEDIT. } \\ \text { H scap } & \text { W-STENOMEDIT. } \\ \text { H bienn } & \text { PALEOTEMP. } \\ \text { H ros } & \text { EURASIAT. } \\ \text { G rhiz } & \text { CIRCUMBOR. } \\ \text { H scap } & \text { EUROSIB. } \\ \text { G rhiz } & \text { PALEOTEMP. } \\ \text { H caesp } & \text { PALEOTEMP. } \\ \text { H caesp } & \text { CIRCUMBOR. } \\ \text { H scap } & \text { EURIMEDIT. } \\ \text { H scap } & \text { CIRCUMBOR. } \\ \text { G rhiz } & \text { COSMOP. }\end{array}$

Helminthotheca echioides (L.) Holub

Sulla coronaria (L.) Medik.

Daucus carota L.

Plantago lanceolata L.

Elymus repens (L.) Gould ssp. repens

Picris hieracioides L.

Convolvulus arvensis L.

Dactylis glomerata L.

Poa pratensis L.

Dittrichia viscosa (L.) Greuter

Artemisia vulgaris L.

Cynodon dactylon (L.) Pers.

$\begin{array}{ccc}+ & + & 4 \\ 1.2 & 1.2 & 3 \\ . & . & 2 \\ . & . & 2 \\ . & . & 1 \\ . & . & 1\end{array}$

Other species

T scap PALEOTEMP.

Trifolium campestre Schreber

G bulb CENTRO-MEDIT.

Bellevalia romana (L.) Sweet

H scap PALEOTEMP.

Lotus tenuis W. et K.

$\mathrm{H}$ caesp EURIMEDIT.

Phleum bertolonii DC.

T scap SUBCOSMOP.

Torilis arvensis (Hudson) Link

$\mathrm{H}$ rept PALEOTEMP.

Trifolium repens $\mathrm{L}$.

T scap EURASIAT.

Avena fatua $\mathrm{L}$.

T scap EURIMEDIT.-TURAN. Vicia sativa L.

H caesp CIRCUMBOR.

Lolium perenne L.

Sporadic species

\begin{tabular}{cccccc}
$\cdot$ & 1.2 & 1.1 & + & + & 4 \\
$\cdot$ & + & + &. & $\cdot$ & 2 \\
$\cdot$ & +.2 & + &. &. & 2 \\
. & +.2 & +.2 &. &. & 2 \\
. &. &. & + & + & 2 \\
. & +.2 &. &. & + & 2 \\
. & + & + &. &. & 2 \\
. & 1.1 & + &. &. & 2 \\
. &. &. & 2.2 & 1.1 & 2 \\
4 & 1 & 1 & 1 & 1 & \\
\hline
\end{tabular}


Table 14 (Tabela 14): Arundinetum plinianae Biondi, Brugiapaglia, Allegrezza \& Ballelli 1992

Inulo viscosae-Agropyrenion repentis

Inulo viscosae-Agropyrion repentis Biondi \& Allegrezza 1996

Agropyretalia repentis Oberdorfer, Müller \& Görs in Oberdorfer, Görs, Korneck, Lohmeyer, Müller, Philippi \& Seibert 1967

Artemisietea vulgaris Lohmeyer, Preising, \& Tüxen ex von Rochow 1951

\begin{tabular}{|c|c|c|c|c|c|c|c|c|c|}
\hline & & Rel. n. & 1 & 2 & 3 & 4 & 5 & 6 & \\
\hline & & & $6 / 23 /$ & $6 / 18 /$ & $6 / 18 /$ & $6 / 18 /$ & $6 / 25 /$ & $6 / 25 /$ & \\
\hline & & Date & 2000 & 1998 & 1998 & 1998 & 2001 & 2001 & \\
\hline & & Altitude (m) & 380 & 305 & 275 & 290 & 280 & 270 & $\dot{0}$ \\
\hline & & Exposure & E & $\mathrm{O}$ & $\mathrm{O}$ & $\mathrm{N}$ & NE & & II \\
\hline & & Slope & $45^{\circ}$ & $40^{\circ}$ & $30^{\circ}$ & $40^{\circ}$ & $20^{\circ}$ & & $\frac{1}{2}$ \\
\hline & & Area & $30 \mathrm{mq}$ & $50 \mathrm{mq}$ & $50 \mathrm{mq}$ & $40 \mathrm{mq}$ & $20 \mathrm{mq}$ & $40 \mathrm{mq}$ & \\
\hline & & Coverage & $100 \%$ & 100 & 100 & 100 & $100 \%$ & $100 \%$ & \\
\hline & & Characteristic and differential species 0 & he asso & ation & & & & & \\
\hline G rhiz & STENOMEDIT. & Arundo pliniana Turra & 5.5 & 5.5 & 5.5 & 5.5 & 5.5 & 4.5 & 6 \\
\hline$P$ caesp & EURASIAT. & Cornus sanguinea L. ssp. sanguinea & + & . & . & . & . & 1.1 & 2 \\
\hline & & Characteristic and differential species o & he allia & ce, orde & and cle & & & & \\
\hline G rhiz & PALEOTEMP. & Tussilago farfara $\mathrm{L}$. & . & + & + & + & . & +.2 & 4 \\
\hline G rhiz & CIRCUMBOR. & Elymus repens (L.) Gould ssp. repens & . & 1.1 & . & +.2 & +.2 & . & 3 \\
\hline G rhiz & PALEOTEMP. & Convolvulus arvensis L. & . & 1.1 & 1.1 & 1.1 & . & . & 3 \\
\hline H scap & EURIMEDIT. & Dittrichia viscosa (L.) Greuter & . & . & . & . & 1.2 & 1.2 & 2 \\
\hline H scap & EURIMEDIT. & Pulicaria dysenterica (L.) Bernh. & + & . & . & + & . & . & 2 \\
\hline H scap & CIRCUMBOR. & Artemisia vulgaris L. & + & . & . & . & . & . & 1 \\
\hline H scap & W-STENOMEDIT. & Sulla coronaria (L.) Medik. & . & . & . & . & + & . & 1 \\
\hline T scap & EURIMEDIT. & Blackstonia perfoliata (L.) Hudson & . & . & . & . & + & . & 1 \\
\hline & & Characteristic and differential species o & he Rhat & no-Pru & tea cla & & & & \\
\hline P caesp & EURIMEDIT. & Spartium junceum L. & . & 1.2 & . & 2.3 & . & + & 3 \\
\hline$P$ caesp & EUROP.-CAUC. & Prunus spinosa L. ssp. spinosa & + & +.2 & . & . & . & + & 3 \\
\hline NP & PALEOTEMP. & Rosa canina $\mathrm{L}$. & . & . & . & . & 1.2 & + & 2 \\
\hline NP & EURIMEDIT. & Rubus ulmifolius Schott & . & . & . & +.2 & . & . & 1 \\
\hline P caesp & PALEOTEMP. & Crataegus monogyna Jacq. & . & 1.1 & . & . & . & . & 1 \\
\hline P caesp & OROF. SW-EUROP. & Cytisophyllum sessilifolium (L.) O. Lang & . & . & . & . & . & + & 1 \\
\hline P lian & EUROP.-CAUC. & Clematis vitalba $\mathrm{L}$. & . & . & . & + & . & . & 1 \\
\hline & & Other species & & & & & & & \\
\hline H scap & OROF. S-EUROP. & Linum viscosum $\mathrm{L}$. & + & + & 1.1 & + & . & . & 4 \\
\hline H scap & OROF. SE-EUROP. & Peucedanum verticillare (L.) Koch & + & + & + & + & . & . & 4 \\
\hline G bulb & CENTRO-MEDIT. & Bellevalia romana (L.) Sweet & . & + & 1.1 & + & . & . & 3 \\
\hline H caesp & PALEOTEMP. & Dactylis glomerata L. & . & . & . & . & + & + & 2 \\
\hline H scap & EUROSIB. & Leucanthemum vulgare Lam. ssp. vulgare & +.2 & . & . & . & . & +.2 & 2 \\
\hline & & Sporadic species & 2 & 0 & 0 & 3 & 6 & 10 & \\
\hline
\end{tabular}


Table 15 (Tabela 15): Alysso alyssoidis-Sedetum albi Oberd. et Th. Mueller in Th. Mueller 61

Alysso alyssoidis-Sedion albi Oberdorfer \& Müller in Müller 1961

Sedo-Scleranthetalia Br.-Bl. 1955

Sedo-Scleranthetea Br.-Bl. 1955 em. Th. Müller 1961

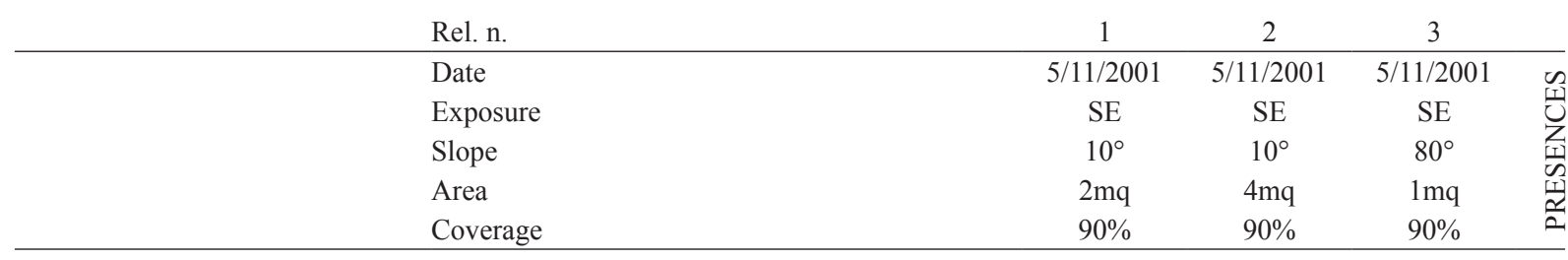

\begin{tabular}{|c|c|c|c|c|c|c|}
\hline & & & & & & \\
\hline Ch succ & EURIMEDIT. & Sedum album $\mathrm{L}$. & 3.3 & 2.3 & 1.2 & 3 \\
\hline Ch succ & EURIMEDIT. & Sedum dasyphyllum $\mathrm{L}$. & 1.2 & 2.3 & . & 2 \\
\hline T rept & EURIMEDIT. & Trifolium scabrum L. ssp. scabrum & 1.2 & 1.2 & . & 2 \\
\hline & & Characteristic and differential species of the $H$ & heme & iti cla & & \\
\hline T scap & EURIMEDIT. & Medicago minima (L.) Bartal var. minima & 1.2 & +.2 & . & 2 \\
\hline T scap & EURASIAT. & Cerastium semidecandrum $\mathrm{L}$. & . & + & +.2 & 2 \\
\hline T scap & STENOMEDIT. & Campanula erinus $\mathrm{L}$. & & 1.1 & & 1 \\
\hline T scap & STENOMEDIT. & Hypochoeris achyrophorus L. & . & . & 1.2 & 1 \\
\hline & & Other species & & & & \\
\hline T scap & EURIMEDIT. & Catapodium rigidum (L.) Hubbard & +.2 & +.2 & +.2 & 3 \\
\hline T scap & STENOMEDIT. & Tordylium apulum $\mathrm{L}$. & 1.1 & +.2 & . & 2 \\
\hline T scap & EURIMEDIT. & Bromus diandrus Roth & + & + & . & 2 \\
\hline H scap & EURIMEDIT. & Geranium pyrenaicum Burm. f. ssp. pyrenaicum & 1.1 & 1.1 & . & 2 \\
\hline T rept & COSMOP. & Stellaria media (L.) Vill. & +.2 & +.2 & . & 2 \\
\hline T scap & EURIMEDIT. & Bromus madritensis L. & +.2 & +.2 & . & 2 \\
\hline T scap & MEDIT.-TURAN. & Crepis sancta (L.) Babc. ssp. sancta & + & + & . & 2 \\
\hline H scap & PALEOTEMP. & Sanguisorba minor Scop. & . & 1.1 & . & 1 \\
\hline H scap & EUROP.-CAUC. & Parietaria officinalis L. & . & + & . & 1 \\
\hline H bienn & MEDIT.-TURAN. & Carduus pycnocephalus L. ssp. pycnocephalus & . & + & . & 1 \\
\hline H scap & S-EUROP.-SUDSIB. & Chondrilla juncea $\mathrm{L}$. & . & + & . & 1 \\
\hline T scap & EURIMEDIT.-TURAN. & Vicia sativa $\mathrm{L}$. & . & + & . & 1 \\
\hline T scap & EURIMEDIT. & Rhagadiolus stellatus (L.) Willd. & . & + & . & 1 \\
\hline T scap & MEDIT.-TURAN. & Astragalus hamosus L. & . & + & . & 1 \\
\hline T scap & STENOMEDIT. & Erodium malacoides (L.) L'Hér. ssp. malacoides & . & + & . & 1 \\
\hline
\end{tabular}


Table 16 (Tabela 16): Linario spuriae-Stachyetum annuae Lorenzoni 1965

Polygono-Chenopodion polyspermi Koch 1926

Solano nigri-Polygonetalia convolvuli (Sissingh in Westhoff, Dijk \& Passchier 1946) Bolòs 1962

Stellarietea mediae Tüxen, Lohmeyer \& Preising ex von Rochow 1951

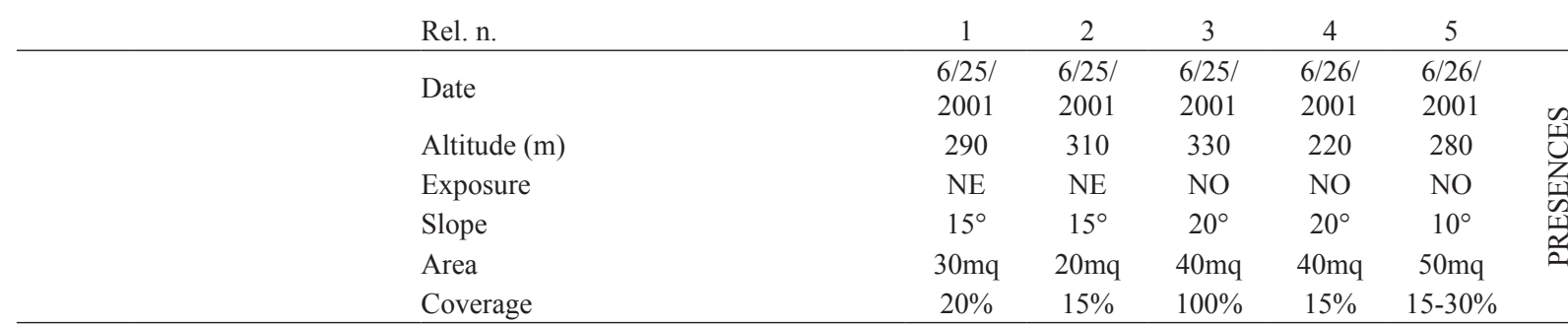

\begin{tabular}{|c|c|c|}
\hline & & Characteristic and differential s \\
\hline T scap & EURIMEDIT. & Helminthotheca echioides (L.) Ho \\
\hline T scap & EURIMEDIT. & Kickxia elatine (L.) Dumort. \\
\hline & & Characteristic and differential s \\
\hline T rept & EURIMEDIT. & Anagallis arvensis $\mathrm{L}$. \\
\hline T scap & AVV. & Thlaspi arvense $\mathrm{L}$. \\
\hline T scap & AVV. & Veronica persica Poiret \\
\hline T scap & CIRCUMBOR. & Fallopia convolvulus (L.) Holub \\
\hline T scap & EURIMEDIT. & Ajuga chamaepitys (L.) Schreber \\
\hline
\end{tabular}

Characteristic and differential species of the class

\begin{tabular}{|c|c|c|c|c|c|c|c|}
\hline T scap & E-MEDIT.-MONT. & Papaver rhoeas L. ssp. rhoeas & 1.1 & 1.1 & + & 1.1 & + \\
\hline T scap & EURIMEDIT. & Lolium multiflorum Lam. & + & 1.1 & 1.1 & + & 1.1 \\
\hline T scap & EURIMEDIT. & Legousia speculum-veneris (L.) Chaix & 1.1 & +.2 & 1.1 & +.2 & . \\
\hline T scap & EURASIAT. & Avena fatua $\mathrm{L}$. & + & 1.1 & 1.1 & . & + \\
\hline T scap & SUBCOSMOP. & Alopecurus myosuroides Hudson & . & + & + & . & +.2 \\
\hline T scap & EURIMEDIT. & Rapistrum rugosum (L.) All. & + & 1.1 & . & . & + \\
\hline T scap & EURIMEDIT. & Nigella damascena L. & . & . & + & + & + \\
\hline T scap & EURIMEDIT. & Consolida regalis $\mathrm{S}$. F. Gray & 1.1 & + & . & . & + \\
\hline T scap & EURIMEDIT. & Sherardia arvensis L. & . & +.2 & . & 1.1 & . \\
\hline T scap & EURIMEDIT.-TURAN. & Vicia sativa $\mathrm{L}$. & . & . & + & + & . \\
\hline T scap & EURASIAT. & Sonchus asper (L.) Hill & + & . & . & . & + \\
\hline T rept & COSMOP. & Stellaria media (L.) Vill. & . & . & . & + & + \\
\hline T scap & PALEOTEMP. & Veronica arvensis $\mathrm{L}$. & . & . & + & + & . \\
\hline T scap & MEDIT.-TURAN. & Papaver argemone L. ssp. argemone & . & $(+)$ & + & . & . \\
\hline T scap & STENOMEDIT. & Anthemis arvensis L. ssp. arvensis & +.2 & + & . & +.2 & 2.2 \\
\hline T scap & EURIMEDIT. & Scandix pecten-veneris $\mathrm{L}$. & . & . & . & + & . \\
\hline T scap & EURIMEDIT. & Lathyrus aphaca L. ssp. aphaca & . & . & + & . & . \\
\hline T scap & PALEOTEMP. & Ranunculus arvensis L. & + & . & . & . & . \\
\hline $\mathrm{G} \mathrm{rad}$ & EURASIAT. & Cirsium arvense (L.) Scop. & . & . & . & + & . \\
\hline T rept & COSMOP. & Polygonum aviculare $\mathrm{L}$. & . & . & . & . & 1.1 \\
\hline T scap & MEDIT.ATL.(EURI) & Adonis anпиа $\mathrm{L}$. & . & . & . & . & + \\
\hline H scap & EURASIAT. & Medicago sativa L. & . & + & . & . & . \\
\hline T scap & PALEOTEMP. & Mercurialis anпиа L. & . & . & . & . & + \\
\hline \multirow[t]{2}{*}{ T scap } & AVV. & Avena sativa $\mathrm{L}$. & . & . & . & + & . \\
\hline & & Other species & & & & & \\
\hline $\mathrm{H}$ bienn & PALEOTEMP. & Daucus carota L. & + & + & + & 1.1 & + \\
\hline T scap & EURASIAT. & Galium aparine L. & + & + & + & + & + \\
\hline G rhiz & PALEOTEMP. & Convolvulus arvensis L. & + & 1.1 & . & 1.1 & + \\
\hline
\end{tabular}


Rel. n.

\begin{tabular}{|c|c|c|c|c|c|c|c|c|c|}
\hline & & Rel. n. & 1 & 2 & 3 & 4 & 5 & 6 & \\
\hline $\mathrm{G} \mathrm{rad}$ & EURASIAT. & Cirsium arvense (L.) Scop. & . & . & . & . & + & + & 2 \\
\hline T rept & COSMOP. & Polygonum aviculare $\mathrm{L}$. & 1.1 & + & . & . & . & . & 2 \\
\hline T scap & EURIMEDIT. & Cerastium glomeratum Thuill. & . & + & + & . & . & . & 2 \\
\hline T scap & PALEOTEMP. & Medicago lupulina $\mathrm{L}$. & . & . & . & +.2 & . & 1.1 & 2 \\
\hline T scap & SUBCOSMOP. & Bromus hordeaceus L. & + & 1.2 & . & . & . & . & 2 \\
\hline H scap & W-STENOMEDIT. & Sulla coronaria (L.) Medik. & . & . & + & +.2 & . & . & 2 \\
\hline T scap & CIRCUMBOR. & Fallopia convolvulus (L.) Holub & . & + & . & . & . & . & 1 \\
\hline T scap & PALEOTEMP. & Fumaria officinalis L. ssp. officinalis & +.2 & . & . & . & . & . & 1 \\
\hline T scap & EURASIAT. & Sonchus asper (L.) Hill & . & . & . & . & . & + & 1 \\
\hline H scap & EURASIAT. & Medicago sativa $\mathrm{L}$. & . & . & . & . & 1.1 & . & 1 \\
\hline T scap & COSMOP. & Euphorbia helioscopia L. ssp. helioscopia & + & . & . & . & . & . & 1 \\
\hline \multirow[t]{2}{*}{ T scap } & EURIMEDIT. & Knautia integrifolia (L.) Bertol. ssp. integrifolia & . & + & . & . & . & . & 1 \\
\hline & & Other species & & & & & & & \\
\hline G bulb & CENTRO-MEDIT. & Bellevalia romana (L.) Sweet & 1.1 & 1.1 & 1.1 & 1.1 & 1.1 & 1.1 & 6 \\
\hline T scap & AVV. & Avena sativa $\mathrm{L}$. & + & 2.2 & 2.2 & 1.2 & 2.2 & 1.1 & 6 \\
\hline T scap & S-EUROP.-SUDSIB. & Geranium columbinum L. & +.2 & 1.2 & + & 2.2 & 1.1 & 2.2 & 6 \\
\hline G rhiz & STENOMEDIT. & Arum italicum Miller ssp. italicum & + & . & . & + & + & + & 4 \\
\hline H scap & EURASIAT. & Vicia cracca $\mathrm{L}$. & + & +.2 & . & 2.2 & +.2 & . & 4 \\
\hline T scap & EURASIAT. & Galium aparine $\mathrm{L}$. & + & . & + & . & + & . & 3 \\
\hline G rhiz & CIRCUMBOR. & Elymus repens (L.) Gould ssp. repens & . & . & . & +.2 & +.2 & +.2 & 3 \\
\hline H scap & EURASIAT. & Ranunculus bulbosus L. & +.2 & + & + & . & . & . & 3 \\
\hline $\mathrm{H}$ bienn & PALEOTEMP. & Daucus carota $\mathrm{L}$. & 1.2 & + & + & . & . & . & 3 \\
\hline G rhiz & PALEOTEMP. & Convolvulus arvensis $\mathrm{L}$. & 1.1 & + & . & . & . & 1.2 & 3 \\
\hline H caesp & CIRCUMBOR. & Poa pratensis L. & + & +.2 & +.2 & . & . & . & 3 \\
\hline T scap & EURIMEDIT. & Vicia tenuissima (Bieb.) Sch. et Th. & . & . & + & . & . & +.2 & 2 \\
\hline \multirow[t]{2}{*}{ H scap } & EUROSIB. & Trifolium pratense $\mathrm{L}$. & . & . & . & . & +.2 & +.2 & 2 \\
\hline & & Sporadic species & 0 & 0 & 1 & 4 & 4 & 0 & \\
\hline
\end{tabular}

